\section{OAK RIDGE NATIONAL. LABORATORY}

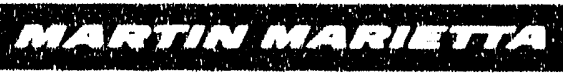

\section{Engine Testing of Ceramic Cam-Roller Followers}

\author{
Final Report
}

Y. Kalish

Prepared by

Detroit Diesel Corporation

Detroit, Michigan

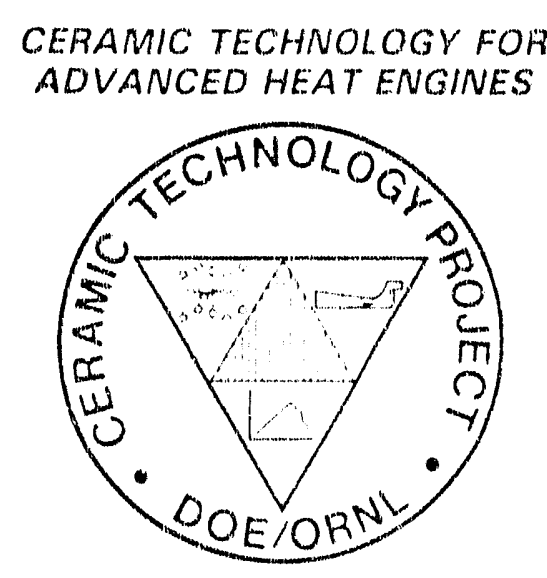

MANAGED BY

MARTIN MBRIETTA ENERGY SYSTEMS, INC.

FRR THE UNITED STATE,

DEPARTMENT OF FNERGY 
This report has been reproducec' directly trom the best available copy.

Aveilable to DOE and DOE contractors from the Office of Scientific and Technical Information, P.O. Box 62, Oak Ridge, TN 37831; prices available from (615) 576.8401, FTS 626-8401.

Available to the public from the National Technical information Service, U.S. Department of Commerce, 5285 Port Royal Rd., Springfield, VA 2.2 181.

This report was prepared as an account of work sponsored by an agency of the United States Government. Neither the United States Government nor any agency thereot, nor any of their employees, makes any warranty, express or implied, or assumes any legal liability or responsibility for the accuracy, com. pleteness, or usefulness of any information, apparatus, product, or process dis. closed, or represents that itid use would not intringe privately owned rights. Reference herein to any specific commercial product. process, or service by trade name, trademark, manufacturer, or otherwise, dces not necessarily constitute or imply its endorsement, recommendation, or favoring by the United States Government or any egency thereof. The viewe and opinions of authors expressed herein do not necesserily state or reflect those of the Unitud States Government or any apency thereot. 


\title{
ENGINE TESTING OF CERAMIC CAM.ROLLER FOLLOWERS
}

\author{
Y. Kalish
}

Date Published-April 1992

\section{FINAL REPORT}

\author{
Prepared by \\ Detroit Diesel Corporation \\ Detroit, Michigan \\ 86X-SF985V
}

\author{
Funded by \\ Office of Transportation Materials \\ Office of Transportation Technologies \\ the Assistant Secretary for Conservation and Renewable Energy \\ U.S. Department of Energy \\ EE 5101000
}

for 1 OAK RIDGE NATIONAI, LABORATORY

Oak Ridge, Tennessee 37831

managed by

MARTIN MARIETTA ENERGY SYSTEMS, INC.

for the

U.S. DEPARTMENT OF ENERGY

under Contract DE-AC05-84OR21400

\section{MASTER}


EXECUTIVE SUMMARY

0.1 objectives............................... 2

0.2 Work statement............................. 2

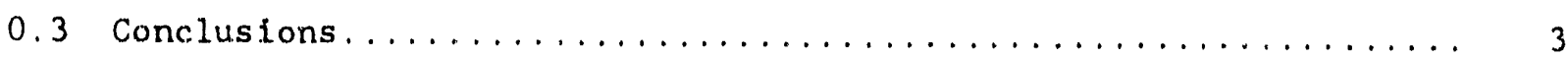

TASK 1 DEFINITION AND TEST OF PRODUCTION FEASIBLE COS'T-EFFECTIVE PROCESS FLOW SHEET

1.1 Fabrication Process.......................... 5

1.1 .1 Supplier of Wide Rollers................... 5

1.1 .2 Supplier of Narrow Rollers.................. 5

1.2 Quality Audit

1.2.1 Procedure for Calculation of Percent Process Capability... 6

1.2.2 Comparison of Process Capability for Domestic and Foreign Produced Rollers.................... 6

1.2 .3 Flexural strength......................... 7

TASK 2 FUNCTIONAL LABORATORY TESTS

2.1 Results of the Tests.......................... 9

2.2 Post-Test Evaluation of the Wide Rollers 2.2 .1 Overspeed Capability Test................... 10

2.2.2 Accelerated wear-Out Test................... 12

2.3 Post-Test Evaluation of the Narrow Rollers............... 13

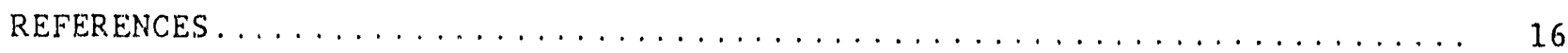




\section{LIST OF FIGURES}

1 Ceramic Can-Roller Follower Drawing ................ 17

2 Wide Rollex Process Flow Chart.................... 18

3 Narrow Roller Process Flow Chart...................... 19

4 Percent Process Capability Comparison................... 20

5 Wide Roller Flexural strength ................... 21

6 Narrow Roller Flexural strength................... 22

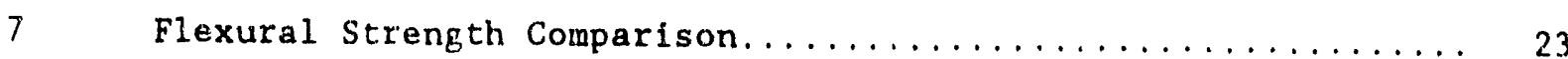

8 Overspeed Capability Test...................... 24

9 Rollers Failed on Overspeed Capability Test............. 25

10 Accelerated Wear-out Test..................... 26

11 Roller Failed on the 1st Cycle of Accelerated Wear-Out Test... 27

12 Roller Failed on the 7th Cycle of Accelerated Wear.Out Test... 28

13 Wide Rollers that Successfully Completed the Accelerated Wear-Out Test................... 29

14 Pins from the Wide Rollers that Successfully Completed the Accelerated Wear-Out Test..................... 30

15 Narrow Rollers that Successfully Completed the Accelerated Wear-Out Test ................... 31

16 Pins from the Narrow Rollers that Successfully Completed the Accelerated Wear-Out Test.................... 32

17 Series 60 Camshaft Aftex Accelerated Wear-Out Test......... 33

18 Injector Lobe of the Series 60 Camshaft Under Wide Roller After Accelerated Wear-Out Test................ 34

19 Intake Lobe of the Series 60 Camshaft Under Narrow Roller After Accelerated Wear-Out Test............... 35

20 Exhaust Lobe of the Series 60 Canshaft Under Narrow Roller After Accelerated Wear-Out Test............... 36

21 Exhaust Lobe of the Series 60 Camshaft Under Wide Roller After Accelerated Wear-Out Test.............. 37 Domestic Ceramic Roller Accelerated Wear-Out Test Results..... 38

23 Pin/Roller Clearance Comparison for wide Rollers............. 39

24 Pin/Roller Clearance Comparison for Narrow Rollers.......... 40

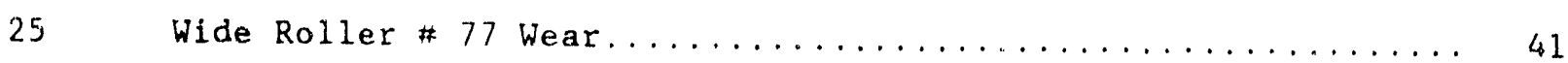

26 ID Surface Trace on the wide Roller $\# 77 \ldots \ldots \ldots \ldots \ldots \ldots \ldots \ldots 42$ 


\section{LIST OF FIGURES}

Eigure

Page

Ceramic Cam-Roller Follower Drawing

Wide Roller Process Flow Chart..................... 18

Narrow Roller Process flow Chart...................... 19

Percent Process Capability Comparison.

Narrow Roller flexural strength................... 22

Flexural Strength Comparison..................... 23

Overspeed Capability Test......................... 24

Rollers Failed on Overspeed Capability Test............. 25

Accelerated Wear-out Test........................ 26

Roller Falled on the 7th Cycle of Accelerated Wear-Out Test...

Wide Rollers that Successfully Completed

the Accelerated Wear-Out Test...................... 29

Pins from the Wide Rollexs that Successfully Completed the Accelerated Wear-Out Test................... 30

15 Narrow Rollexs that Successfully Completed the Accelerated Wear-Out Test.................... 31

Pins from the Narrow Rollers that Successfully Completed the Accelerated Wear-Out Test................... 32

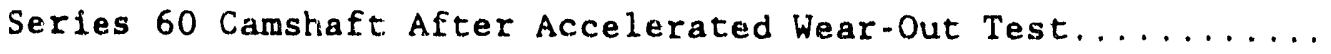

Injector Lobe of the Series 60 Camshaft Under Wide Roller After Accelerated Wear.Out Test................. 34

19 Intake Lobe of the Series 60 Camshaft Under Narrow R.oller After Accelerated Wear-Out Test............... 35

Exhaust Lobe of the Series 60 Camshaft Under Narrow Roller After Accelerated Wear-Out Test.............. 36

Exhaust Lobe of the Series 60 Camshaft Under Wide Roller After Accelerated Wear-Out Test............... 37 Domestic Ceramic Roller Accelerated Wear-Out Test Results..... 38 Pin/Roller Clearance Comparison for wide Rollers............ 39

24 Pin/Roller Clearance Comparison for Narrow Rollers.......... 40

25 Wide Roller \# 77 wear........................ 41

26 ID Surface Trace on the wide Roller $\# 77 \ldots \ldots \ldots \ldots \ldots \ldots \ldots$ 


\section{LIST OF FIGURES (CONTINUED)}

Figure

Page

27

ID Surface Finish Near Edge of the wide Roller $\# 77 \ldots \ldots \ldots \ldots$

ID Surface Finish Near the Center of the wide Roller $\# 77 \ldots \ldots, 44$

29

Photomicrographs of the Wide Roller ID Wear............. 45

30

Wide Roller \#80 Wear.

46

31

ID Surface Trace on the Wide Roller \# 80

47

32

ID Surface Finish Near Edge of the Wide Roller $\# 80$.

48

ID Surface Finish Near the Center of the wide Roller \#80,....

Crown Profiles of the Narrow Rollers After Overspeed

Capability Test............................. 50 


\section{ABSTRACT}

The purpose of the project was to inspect and test 100 domestically produced silicon nitride can-roller followers built to the requirements of the DDC Series 60 engine.

\section{INTRODUCTION}

For several years, DDC has been developing monolithic ceramic heat engine corponents. One of the components, developed for an application in our state-of-the-art on-highway, heavy-duty diesel engine, the Series 60 , is a silicon nitride cam-roller follower (see figure 1). Prior to starting this program, each valve train component in the Series 60 was considered for conversion to a ceramic material. Many advantages and disadvantages (benefits and risks) were considered. From this effort, one component was selected, the cam-roller follower. Using a system design approach, a ceramic cam-roller follower offered functional improvement at a reasonable cost.

Initially, two suppliers participated in ceramic cam-roller follower development, one domestic and one foreign. During the development process the domestic supplier elected to cease participation in the project. The main reasons for this action were: inability to make prototypes to specification; lack of funds to scale-up; and inability to define a production feasible, costeffective process.

Recently two domestic suppliers expressed interest in DDC's effort. Furthermore, their materials appeared to meet DDC requirements. DDC has also developed expertise in statistical process capabilities and functional. tests of silicon nitride rollers. In order to promote development of domestic ceramic engine component suppliers, this contract was awarded to DDC to inspect and test 100 domestically produced silicon nitride cam-roller followers for the Series 604 -cycle, $275-450$ hp diesel engine.

Research sponsored by the U.S. Department of Energy, Assistant Secretary for Conservation and Renewable Energy, Office of Transportation Technologies, as part of the Ceramic Technology Project of the Advanced Materials Developinent Program, under contract DE-ACO5-840R21400 with Martin Marietta Energy Systems, Inc., Work Breakdown Structure Subelement 3.3.1.8. 


\section{EXECUTIVE SURMARY}

\subsection{Objectives}

The objectives of this project were to inspect and test 100 domestically produced silicon nitricle cam-roller followers built to the requirements of the Detroit Diesel Corporation's Series 60 4-cycle, 275-450 hp diesel engine. The ilspection and functional laboratory tests were consistent with those previously performed on foreign produced cam-roller followers. Therefore, results from these efforts could also be compared with previous data from foreign produced ceramic rollers.

The tasks of the project are summarized in the following work statement.

\subsection{Work Statement:}

\section{Task 1 Definition and Test of Production Feasible Cost-effective Process Flow Sheet}

Identification of a high-volume, production feasible process flow sheet and fabrication of 50 consecutively produced wide and 50 consecutively produced narrow cam-roller followers. This task also includes dimensional and surface finish inspection of each part, and a statistical "process capability" calculation for each dimension.

\section{Task 2 Functional Laboratory Tests}

Overspeed capability test and a 100,000 equivalent mile accelerated wear test. Both tests were performed on a cylinder head rig. Results were compared to foreign produced silicon nitride cam-rolier followers tested under the same conditions.

\section{Task 3 Reporting}

A detailed final repoxt describing domestically produced silicon nitride cam-roller follower activities. 


\section{0,3 Conclusions}

1. Process capability of the foreign produced silicon nitride cam-roller followers is higher than domestically produced cam-roller followers. In the case of foreign produced wide rollers, all ten parameters reviewed were acceptable or marginal, while only six were marginal or acceptable for the domestically produced wide rollers. Nine parameters out of ten were acceptable or marginal for the foreign produced narrow rollers. However, only two parameters for domestically produced narrow rollers were acceptable or marginal.

2. Both silicon nitride materials fabricated by the domestic sources of wide rollers and narrow rollers meet DDC requirements for the minimum and $B-1$ flexural strength. Average flexural strength of both domestically produced materials is higher than that of the foreign produced material. Weibull modulus of the material, fabricated by the supplier of wide rollers, is comparable to the foreign produced material. Weibull modulus of the material, fabricated by the supplier of the narrow rollers, is lower than that of the foreign produced material.

3. Wide rollers performed satisfactorily on the overspeed capability test. No failures were observed. However, two narrow rollers failed during the overspeed capability test. No foreign produced rollers ever failed on this test.

4. Two narrow rollers failed during the accelerated wear-out test. The camshaft was worn extensively under both wide and narrow rollers. Pin/roller clearance, which increases as either the roller ID or pin OD wears, increased during the test for both wide and narrow rollers. Practically no change in $\mathrm{p} i \mathrm{n} / \mathrm{roller}$ clearance was observed for the foreign produced rollers, and no failures were observed.

5. Extensive wear of both wide and naisow rollers can be traced to dimensional nonconformance, caused by machining problems. Improvements in machining are necessary to decrease the wear rate. 
6. Failures of the narrow rollers, on both overspeed capability and accelerated wear-out tests, also may be due to problems with material and/or the fabrication process. Failure of one MOR test bar due to a flaw and low sintered density of a failed roller support this conclusion.

7. Surface roughness of the $O D$ and ID deserves additional attention. Surface roughness was within spec for the wide and narrow rollers and decreased on roller $O D$ and ID during the wear-out test. Excessive initial surface roughness will lead to a failure. Therefore, determinatiol of a surface roughness limit would be benefitial for controlling machining costs. 


\section{TASK 1 DEFINITION AND TEST OF PRODUCTION FEASXBLE COST-EFFECTIVE PROGESS FLOW SHEET}

\subsection{Fabrication Process}

In order to evaluate both domestic suppliers it was decided to procure wide $(23.45 \mathrm{~mm}$ width) and narrow (12.15 $\mathrm{mm}$ width) cam-roller followers from different suppliers. Wide rollers were fabricated by Supplier "A", and narrow rollers were fabricated by Supplier "B".

\subsection{Supplier of Wide Rollers}

Sintered SiAlON material was used to fabricate wide cam-roller follcwers. The fabrication process flow chart is shown in Figure 2.

A total of thirty-six (36) rollers and process control data for fifty (50) consecutively manufactured rollers were submitted to Detroit Diesel Corporation.

Rollers were crowned by the supplier internally on experimental tooling, since the outside machining source expected to do the crowning operation backed out of the project at a late date. This contributed to some nonconformance in ID-OD parallelism and OD roundness.

\subsubsection{Supplier of Narrow Rollers}

Dry pressed, gas pressure sintered silicon nitride material was used for the fabrication of narrow cam-roller followers. The fabrication process flow chart is shown in Figure 3 .

A total of seventy-nine (79) narrow silicon nitride ceramic cam-roller followers were fabricated. During final measurement of component properties, an accident occurred. Rollers \#01 through \#49 were dropped from a measurement bench and forty (40) of these rollers sustained chip damage. Detroit Diesel Corporation approved acceptance of thirty-six (36) rollers and the data for all seventy-nine (79). 


\section{Quality Audft}

\section{Procedure for Calculation of Percent Process Capability}

Detroit Diesel Corporation used procedures outlined in (1) for the calculation of percent process capability. The Process Capability (PC) is equal to six standard deviations, as calculated from component measurements, 1.e.:

$P C-6 s$

where $s-R / d$

and $R-R / n^{2}$

where $B$. Is the salnple range (maximum - minimum dimension in a sample)

$n_{s}$ is the nurber cf rational subgroups ( we usually use

10 rational subgroups, with 5 samples in each)

$d_{2}$ is a Shewhard constant $\left(d_{2}-2.326\right.$ for the subgroup size of 5 )

Therefore, percent process capablifty, FCH, can be expressed as:

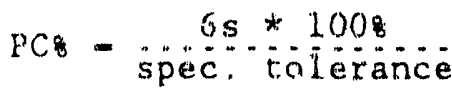

Processes with PC of less than 70 are considered acceftable, between $70 z$ and 100 - marginal, and a PCo of more than 1008 is unacceptable.

This procedure was used to evaluate dimensional capability of foreign and domestically produced rollers.

\subsection{Comparison of Process Capability for Domestic and Forelgn Produred Rollers}

Percent process capability was calculated for the following ten key characteristics: $O D$ size; ID size; width; $O D$ finish; ID finish; OD roundness; ID roundness; $O D$ crown; ID-OD parallelism; and ID-OD runout. Results are shown in Figure 4.

Both narrow and wide cam-roller followers, fabrlcated by one forelgn supplier, were tested at DDC. Results show that, in general, it is more difficult to meet dimensional requirements for the narrow rollers than requirements for wide rollers 
Both domestlc suppliers fell sho of achieving the prucess capability of the forefgn supplier. For wide rollers, all dimeisions on the foreign produced rollers were acceptable (percent process capability was within the internal DDC requirement of 708 for all ten characteristics). Domestically produced wide rollers had only 5 acceptable characteristics, 1 marginal and 4 were unacceptable. For narrow rollers, only 4 characteristics on the foreign produced rollers were acceptable, 5 were marginal and 1 was unacceptable. Dowestically produced narrow rollers had only 2 acceptable characteristics, and five characteristics were unacceptable. Since a go/no-go gage was used for three other parameters, we could not calculate percent process capability for them.

\section{2 .3 Flexural Strength}

According to DDC's ceramic cam-roller follower material specification [2], the minimum flexural strength of the roller must be $420 \mathrm{MPa}$, determined by a four-print bend test at room temperature. Test bar specimens have the following dimensions: $60 \mathrm{~mm}$ long $x 4 \mathrm{~mm}$ wide $z 3 \mathrm{~mm}$ thick. The supplier is required to perform the flexural strength test on a fourteen (14) piece sample for every new lot of material. The B-1. MOR strength must be at least $380 \mathrm{MPa}$, calculated using two parameter weibull statistics and least square linear regression, on a minimum of fourtnen median ranked MOR samples.

Wide rollers were fabricated from one powder lot and one sintering run. Therefore, wide rollers represent one material lot, \#A010202. Data for a total of 25 test bars was submitted and statistically processed at DDC. Results are shown in Figure 5. The material meets DDC specification for MOR strength. Weibull modulus for 25 bars was 16 .

Two different powder lots (90L-998 and 91A-004) were utilized for the Eabrica. tion of narrow rollers. Three different sintering runs (90L-998, 91A-004A, 91A-004B) were performed. Therefore, narrow rollers represent three different material lots. Data for a total of 42 test bars ( 14 for each material lot) was submitted and statistically processed at DDC. Combired results for three lots are presented in Figure 6 . The Weibull moduli for three lots were different: 7.5 for lot \#91A-004B; 17 for lot \#90L-998; and 32 for lot \#91A-004A. The Weibull modulus for all 42 test bars was 10 . The low weibull modulus of lot 
\#1A-004B was due to test bar \#13. Fractography was performed on this specimen and the failure origin was found to be a near surface agglomerate/pore cluster.

Figure 7 shows the comparison of the flexural strength for three silicon nitrides; (1) foreign produced; (2) wide roller domestic material; and, (3) narrow roller domestic material. Data for 150 MOR te:t bars was statistically processed for the foreign produced material.

The average strength of both domestic ceramic materials is higher than that of foreign material. Howevrer, based on all N.JR bars tested, both forelgn and domestic, the lowest strength sample was a domestic material, fabricated by the cupplier if narrow rollers. The Weibull modulus of the domestic wide roller material is comparable to that of foreign produced silicon nitride. It may ciecrease, though, for production quantities of material. If it does not, the domestic material could have a high Weibull modulus and a flexural strength higher than required for this application. This could lead to a future cost savings. The Weibull modulus of the narrow rollers material is much lower than that of the foreign produced silicon nitride. Due to iite high average flexural strength, narrow rollers material still met DDS requirements for minimum and B-1 strength, despite the low Weibull modulus. 
Changes in the pin/roller clearances, weights of the rollers, and camshaft wear are quantified in Figure 22. Measurements showed that some rollers actually gained weight. This was caused by carbon deposits from the oil on the ID of the rollers.

No'ne of the foreign produced rollers, wide or narrow, failed during the overspeed capability or accelerated wear-out tests. During the program, domestic ceramic rollers wore more than foreign rollers. Figures 23 and 24 compare the change in pin/roller clearance for wide and narrow domestic and foreign rollers.

Post test evaluation was performed by the suppliers. Separate reports for overspeed capability and accelerated wear-out tests were submitted by the supplier of wide rollers. The supplier of narrow rollers submitted one report that covered both tests.

\subsection{Post Test Evaluation of the Wide Rollers}

\section{2 .1 Overspeed Capability Test}

Two rollers, along with the corresponding roller pins (sets \#77 and 80 ), were evaluated after the overspeed capability test. Of major concern was discoloration and wear evident on the metal roller pins.

Visual review of roller/pin set $\$ 77$ found vexy little indication of wear on the roller OD. The roller ID had a visible dark band, indicating wear had occurred near the center of the part (see figure 25a). The pin had also sustained wear in the center (see Figure 25b).

A Rank Taylor Hobson Form Talysurf was used to analyze the wear on the roller ID. A surface trace was run from end to end on the ID. This trace is shown in Figure 26. The surface profile indicates that the ID is slightly "bell mouthed". Also, the character of the surface profile in the center of the roller reflects the wear that occurred during testing. Peak heights at the center are somewhat reduced compared to the finish at either end. 


\section{TASK 2 FUNCTIONAL LABORATORY TESTS}

\subsection{Results of the Tests}

An outline of the overspeed capability test is shown in Figure 8 . It consists of nine (9) engine RPM levels, from 3300 to 4100 RPM. (Note: the Series 60 rated speed is $2100 \mathrm{RPM}$;. Nine wide rollers were tested - six in the infector rocker arms and three in the exhaust rocker arms. All wide rollers completed the test. Nine narrow rollers were tested - six in the intake rocker arms and three in the exhaust rocker arms. Two narrow rollers in exhaust rocker arm positions failed during the test, both on the third RPM level. (see Figure 9). Three narrow rollers, including two that failed, and two wide rollers were returned to their suppliers for evaluation after tine overspeed test was completed.

An outline of the accelerated wear-out test is shown in Figure 10 . It consists of seven (7) cycles, and corresponds to running the engine for 100,000 equivalent miles. Nine wide rollers were tested - six in the injector rocker arms and three in the exhaust rocker arms. All wide rollers completed the test. Nine narrow rollers were tested - six in the intake rocker arms and three in the exhaust rocker arms. Two narrow rollers in the exhaust rocker arm positions failed during the test. One failed during the first cycle (see Figure 11 ) and another during the seventh cycle (see Figure 12). Three narrow and two wide rollers (including two failed narrow rollers) were returned to the suppliers for the post test evaluation.

Wide rollers and pins that successfully completed accelerated wear-out test are shown on Figures 13 and 14. Narrow rollers and pins that successfully completed the accelerated wear-out test are shown in Figures 15 and 16. Cam lobes on the Series 60 camshaft used in this test were extensively worn, see Figure 17. The most wear occured on injector lobes (see Figure 18) under wide ceramic rollers and exhaust lobes under narrow ceramic rollers (see figure 20). Less wear occured on intake lobes (see Figure 19) under narrow ceramic rollers and exhaust lobes under the wide ceramic rollers (see Figure 21). 
Figures 27 and 28 are higher resolution profiles of sections from the profile shown in Figure 26. Figure 27 is a section taken near the edge of the roller, and Figure 28 is a section taken in the wear area at the center of the part. There is a subtle difference in the surface traces, the wear area shown in Figure 28 has more truncated peaks and a predominance of valleys in the surface profile. The data that accompanies each trace verifies perceived differences. Note that the $R a$ value in Figure 27 (near the edge) is .204 um. In the wear area (Figure 28) the $\mathrm{Ra}$ is $.1 .71 \mathrm{um}$. The $\mathrm{Rp}$ and $\mathrm{Rpm}$ values, a measure of peak height above the profile mean, reflect the reduced peak height in the wear area.

Roller \#77 was sectioned and submitted for Scanning Electron Microscope (SEM) analysis. Figure 29 represents photomicrographs from this analysis showing the ID wear area at 50x, and 250x. A porous surface is evident. The apparent elongation of the pores indicates some spalling and bridging between pores has occuried in the weir area. The horizontal lines seen on the first (Figure 29a) are grinding marks.

The OD of roller \#80 appeared to have sustained more wear during testing than \#77. The witness mark left from contact with the cam tracked unevenly around the circumference of the roller. This condition is related to ID-OD parallelism. The measured value of $0.02 \mathrm{~mm}$ is greater than the print specification of $.01 \mathrm{~mm}$. This nonconformance is docurnented by the Initial Sample Inspection Report that was submitted to DDC with this part. Figure 30a is a $2 \mathrm{x}$ photograph of the wear mark. Figures $30 \mathrm{~b}$ and $30 \mathrm{c}$ are photographs of the wear on the roller ID and the roller pin.

The \#80 roller ID was analyzed with the Form Talysurf instrument. Figure 31 is a trace of the surface profile of the ID from end to end. Again, the profile indicates some bell mouthing is present, with the center of the part raised in relation to the ends. However, this condition appears to be less symmetrical on roller $\# 80$ than it was on $\# 77$. The expanded profile sections and data presented in Figures 32 and 33 indicate that wear occurred in the raised center of the ID. 
Roller $\# 80$ suffered the most severe burnishing of the two wide rollers analyzed by the supplier after completion of the overspeed capability test. Inspection docurnents indicated that this part was not to print and shipped under deviation for ID-OD parallelism. This condition was the result of the crowning operation employed by the supplier. The ID-OD parallelism was in specification prior to the crowning operation. As mentioned earlier, the supplier of the wide rollers was forced to crown the rollers internally.

The profile traces indicate a small degree of bell mouthing on the roller IDs, $0.0001 "$ to $0.0002 "$. This was not detected during the initial inspection. However, in the post test analysis, using precision bnre gages, suggested a slight degree of bell mout'.ing. This may have contributed to the burnishing of the roller pins. This condition could be the result of precision honing operations used during ID finishing.

The visual low density band seen on the wide rollers appears to have caused no wear problems in the overspeed capability test. No measurable wear was noted on the crowns of the returned pieces.

Profile traces were run on the steel pins returned with the ceramic rollers. Pins measure straight and round.

\subsubsection{Accelerated Wear-out Test}

Two rollers and the corresponding pins $\# 8$ and $\# 55$, run on the accelerated wear-out test, were subject of the post test evaluation by the supplier.

Visual review of roller/pin set \#8 found very little indication of wear on the roller $O D$. The roller ID had a visible dark band indicating wear had occurred near the center of the part. Aiso, the pin had sustained wear visible in the center of its OD.

The Rank Taylor Hobson Form Talysurf was used to analyze the wear on the ID of the roller. A surface trace was run from end to end on the ID. The surface profile indicates that the ID is rightly bell mouthed. Also, the surface finish in the center reflects the wear that occurred in testing, peak heights 
are somewhat reduced compared to the finish at either end of the roller. There is a subtle difference in the surface traces near the edge of the roller and at the center of the part. The wear area near the center of the part has more truncated peaks and a predominance of valleys in the profile. The Ra value near the edge of the roller is $.110 \mathrm{um}$, and in the wear area the $\mathrm{Ra}$ is $.090 \mathrm{um}$. Also, the Rpm values, a measure of peak height above the profile mean, reflect a reduced peak height in the wear area.

A surface trace from the $O D$ was also analyzed. As with the ID, a slight amount of wear was present. Near the edge of the roller the roughness average was $.149 \mathrm{um} \mathrm{Ra}$, and the peak height average above the mean was $.413 \mathrm{um} \mathrm{Rpm}$. Near the center of the roller, these values were reduced to $.119 \mathrm{um} \mathrm{Ra}$ and $.345 \mathrm{um}$ Rpr, respectively.

Roller/pin set \#55 was examined for wear using the Form Talysurf instrument. The inside diameter of this roller showed no wear. Two surface roughness traces were made on this part. One trace was made near the end of the ID, and a second trace near the center. There was no difference in the appearance of the traces or in the roughness data.

The outside diameter of roller \#55 was examined for wear. Again two surface roughness traces were made, one near the edge, and one near the center. Some wear was detected. A reduction in the roughness average from $.138 \mathrm{um}$, near the end, to $.086 \mathrm{um}$, near the center indicated wear. Also, a reduction in the average peak height above the mean line, from .310 um to .186 um, tended to confirm the wear near the center of the $O D$.

\subsection{Post Test Evaluation of the Narrow Rollers}

Three narrow rollexs from each of functional tests were returned to the supplier of narrow rollers for post test evaluation. These rollers were evaluated visually, dimensionally, for surface rouginess (of roller OD and ID and pin $O D)$, and with a profileometer to measure $O D$ crown height and symmetry.

The two failed rollers from the overspeed capability test had one OD edge spalled along the entire circumference. The spalling ran roughly $2.00 \mathrm{~mm}$ (12 mm 
total width) across the $O D$, and $5 \mathrm{~mm}$ down the side of the roller (9 $\mathrm{mm}$ total thickness). These rollers, \#65 and \#67 were taken off the overspeed capability test after the third (of nine) RPM step. The two failed rollers from the accelerated wear-out test had very different failure modes. Roller \#69 had a large single spall that ran from the OD to the ID of the roller, while roller \#7 had a chipped flake removed from the OD surface - $6.3 \mathrm{~mm}$ long $\times 4.2 \mathrm{~mm}$ wide $\times 0.01 \mathrm{~mm}$ deep. Roller \#77 failed during the first of seven cycles while \#69 failed cluring the seventh cycle.

The visual condition on the ID of the rollers varied from "unused" to extensive dark discoloration. The extent of this discoloration on roller ID generally indicated the extent of wear on the OD of the pins. However, the ID's of the rollers did not show any spalling or flaking of corners or running surfaces. Therefore, the ID condition was not a precondition for the failure of the $O D$. There was no discernible difference in the OD and ID dimensions after testing, compared to pretest dimensions. However, the surface roughness on the OD of the rollers that passed each test was significantly lower than the surface roughness of the failed rollers. Where there was discoloration on the roller ID, the surface was smoother in three of the six samples, stayed the same in two samples, and was made noticeably rougher in only one sample - \#65. The ID of sample \#65 had small processing pits that were enlarged by wear during the accelerated wear-out test. The pin wear was characterized by an increase in surface roughness that ranged from $0.07 \mathrm{um}$ to $0.27 \mathrm{um}$.

The profile of the crown on the OD of the rollers (see Figures 34 and 35) appears to be the most influential property that determines whether a roller passed or falled a given test. Narrow rollexs returned by DDC to the supplier, that had passed a given test, had a crown of at least 50 microinches $(0.0013$ $\mathrm{mm}$ ) (Figures $34 \mathrm{a}$ and $35 \mathrm{a}$ ). Three rollers that had edge spalls had crowns of less than 30 microinches $(0.0008 \mathrm{~mm}$ ) (Figures $34 \mathrm{~b}, 34 \mathrm{c}$ and $35 \mathrm{~b}$ ). Narrow roller \#7 had a symmetrical crown of 40 microinches $(0.0010 \mathrm{~mm}$ ) (Figure $35 \mathrm{c}$ ). Its spall, that ran across the surface of the OD, was most likely caused by low sintered density $(3.125 \mathrm{~g} / \mathrm{cc}$ vs typical $3.22 \mathrm{~g} / \mathrm{cc})$. Roller \#60 from the accelerated wear-out test showed hardly any visual wear on the OD and ID, and it passed the test. It also has the highest density of the 
six rollers returned for the post test evaluation, $3.226 \mathrm{~g} / \mathrm{cc}$ (theoretical density $=3.25 \mathrm{~g} / \mathrm{cc})$. Roller $\# 60$ has a pronounced peak to its oD profile, with a 60 microinch $(0.0015 \mathrm{~mm})$ rise at the center of the roller.

After examining the various dimensions and characteristics of failed and passed narrow cam-roller followers, there are three features that stand out as the prime cause of OD chipping and spalling. The most important causes of spalled edges was a crown of less than 40 microinches $(0.0010 \mathrm{~mm})$, at the low end of the spec limit, and/or poor symmetry of the roller crown. Low density of the sintered $\mathrm{Si}_{3} \mathrm{~N}_{4}$ roller can also lead to spalling of the load bearing surface of the OD. Surface roughness must also be kept to as low a level as possible, below 6.00 microinch $(0.15 \mathrm{um})$, as indicated by these preliminary results.

A characteristic that did not correspond to spall type failure was out-of-roundness. Those rollers that passed each type of DDC test had out-of-roundness that exceeded that of three of the four failed rollers. 


\section{REFERENCES}

1. General Motors Manufacturing Systems Qualification Manual. General Motors Corporation, January 1987

2. Detroit Diesel Corporation Material Quality Specification \#90K178 "Material Acceptance Criteria for Series 60 Silicon Nitride Cam Rollers", rev. 6-24-91 


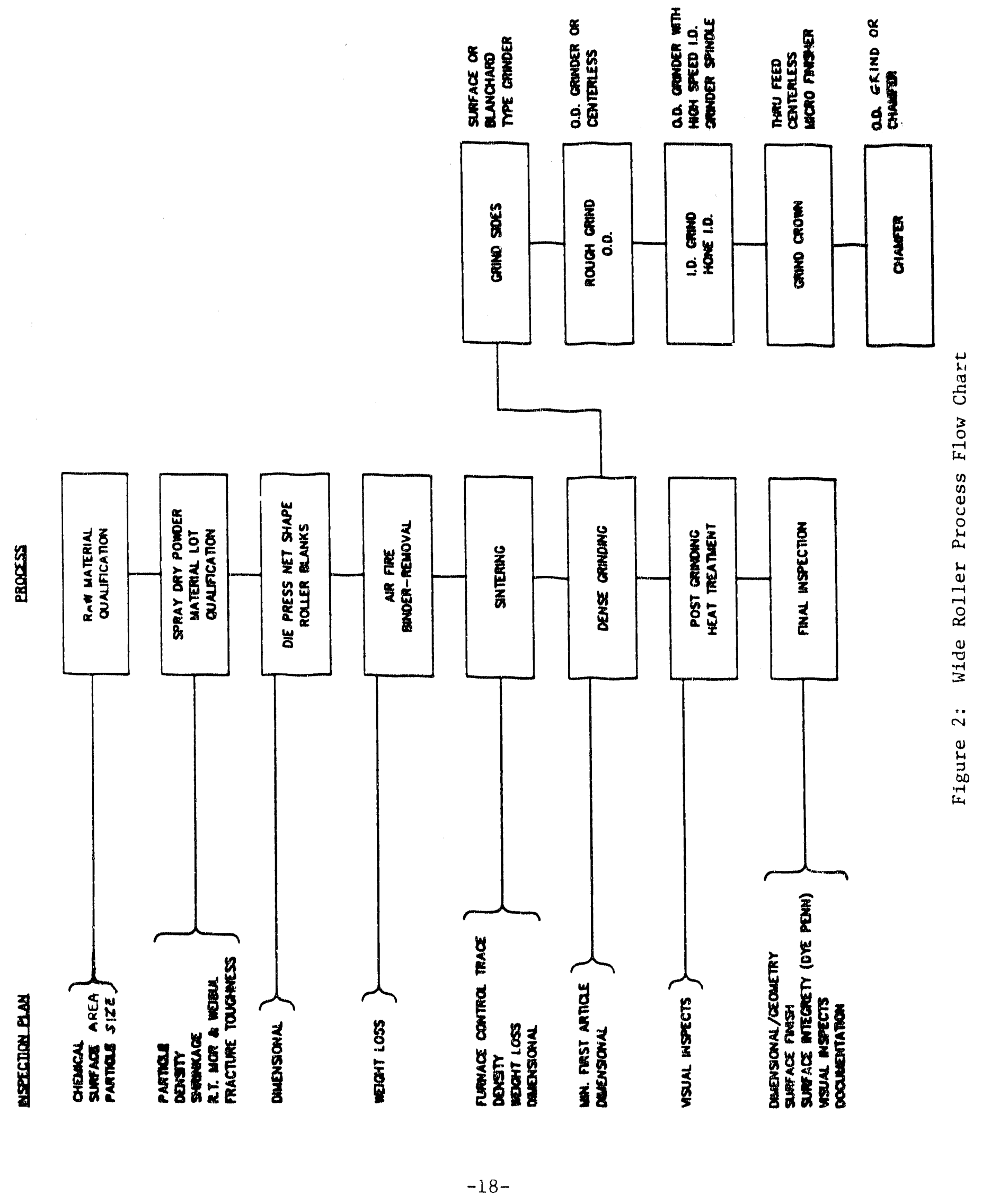


POHDER BATCHING:

Silicon Nitride, Sinter Aids, Binders, D. I. Water

\section{POWDER HET MIXING:}

Process Checks; pH, Viscosity, Specific Gravity

SPRAY DRYING:

Process Checks; RPM-Atomizer, Chamber Temperature

\section{SCREENING:}

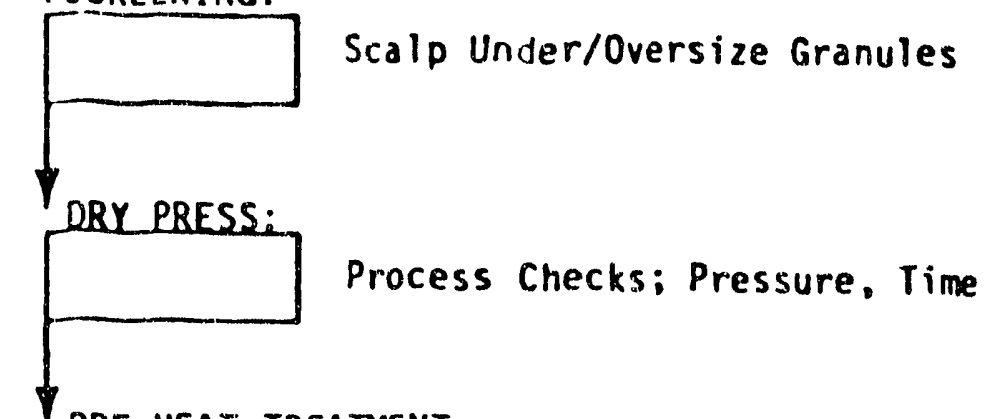

PRE-HEAT TREATMENT:

Process Checks; Height Loss, Visual Inspection

\section{SIHTERING:}

Process Checks; Density. Shrinkage. Visual Inspection

\section{MACHINING:}

Process Checks; Dimensions. Surface Roughness

\section{FINAL INSPECTION:}

Density, Dye Penetration, Visual Inspection, Flexure Strength, Fracture Toughness, Hardness

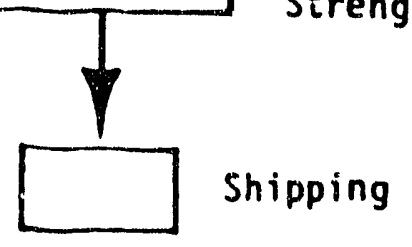

Figure 3: Narrow Roller Process Flow Chart 
Series 60 Ceramic Rollers - Wide

\begin{tabular}{|c|c|c|c|}
\hline Feature & $\begin{array}{c}\text { Total } \\
\text { Tolerance } \\
\text { (mm) }\end{array}$ & $\begin{array}{l}\text { Kyocera's } \\
\text { Process } \\
\text { Capability }\end{array}$ & $\begin{array}{c}\text { Domestic } \\
\text { Process } \\
\text { Capability }\end{array}$ \\
\hline $\begin{array}{l}\text { OD size } \\
\text { ID size } \\
\text { width }\end{array}$ & $\begin{array}{l}0.10 \\
0.01 \\
0.10\end{array}$ & $\begin{array}{ll}50 & (+) \\
70 & (+) \\
62 & (+)\end{array}$ & $\begin{aligned} 56 & (+) \\
251 & (-) \\
38 & (+)\end{aligned}$ \\
\hline $\begin{array}{l}\text { OD finish } \\
\text { ID finish }\end{array}$ & $\begin{array}{l}0.2 \\
0.2\end{array}$ & $\begin{array}{l}63(+) \\
36(+)\end{array}$ & $\begin{aligned} 43 & (t) \\
108 & (*)\end{aligned}$ \\
\hline $\begin{array}{l}\text { OD roundness } \\
\text { ID roundriess }\end{array}$ & $\begin{array}{l}0.003 \\
0.003\end{array}$ & $\begin{array}{ll}53 & (+) \\
69 & (+)\end{array}$ & $\begin{array}{ll}136 & (-) \\
131 & (-)\end{array}$ \\
\hline$O D$ crown & 0.015 & $46(+)$ & $32(t)$ \\
\hline $\begin{array}{l}\text { ID, OD parallelism } \\
\text { ID, OD runout }\end{array}$ & $\begin{array}{l}0.01 \\
0.08\end{array}$ & $\begin{aligned} 52 & (+) \\
7 & (+)\end{aligned}$ & $\begin{aligned} 417 & (-\infty) \\
41 & (+)\end{aligned}$ \\
\hline rotals & $\begin{array}{cc}\text { Acceptable } & (+) \\
\text { Marginal } & (*) \\
\text { Unacceptable } & (-)\end{array}$ & $\begin{array}{r}10 \\
0 \\
0\end{array}$ & $\begin{array}{l}5 \\
1 \\
4\end{array}$ \\
\hline
\end{tabular}

Series 60 Ceramic Rollers - Narrow

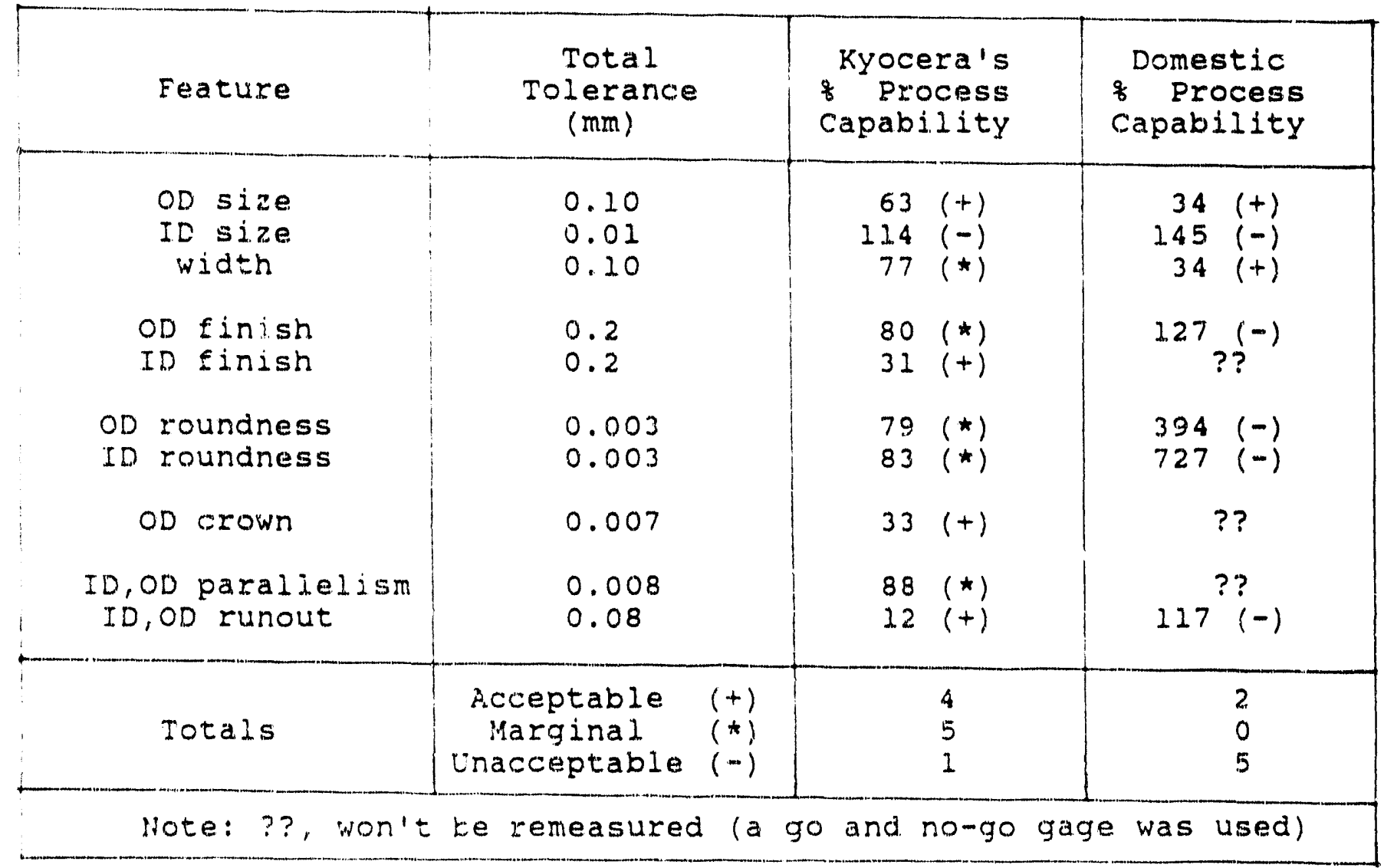

Figure 4. Percent process capability comparison 


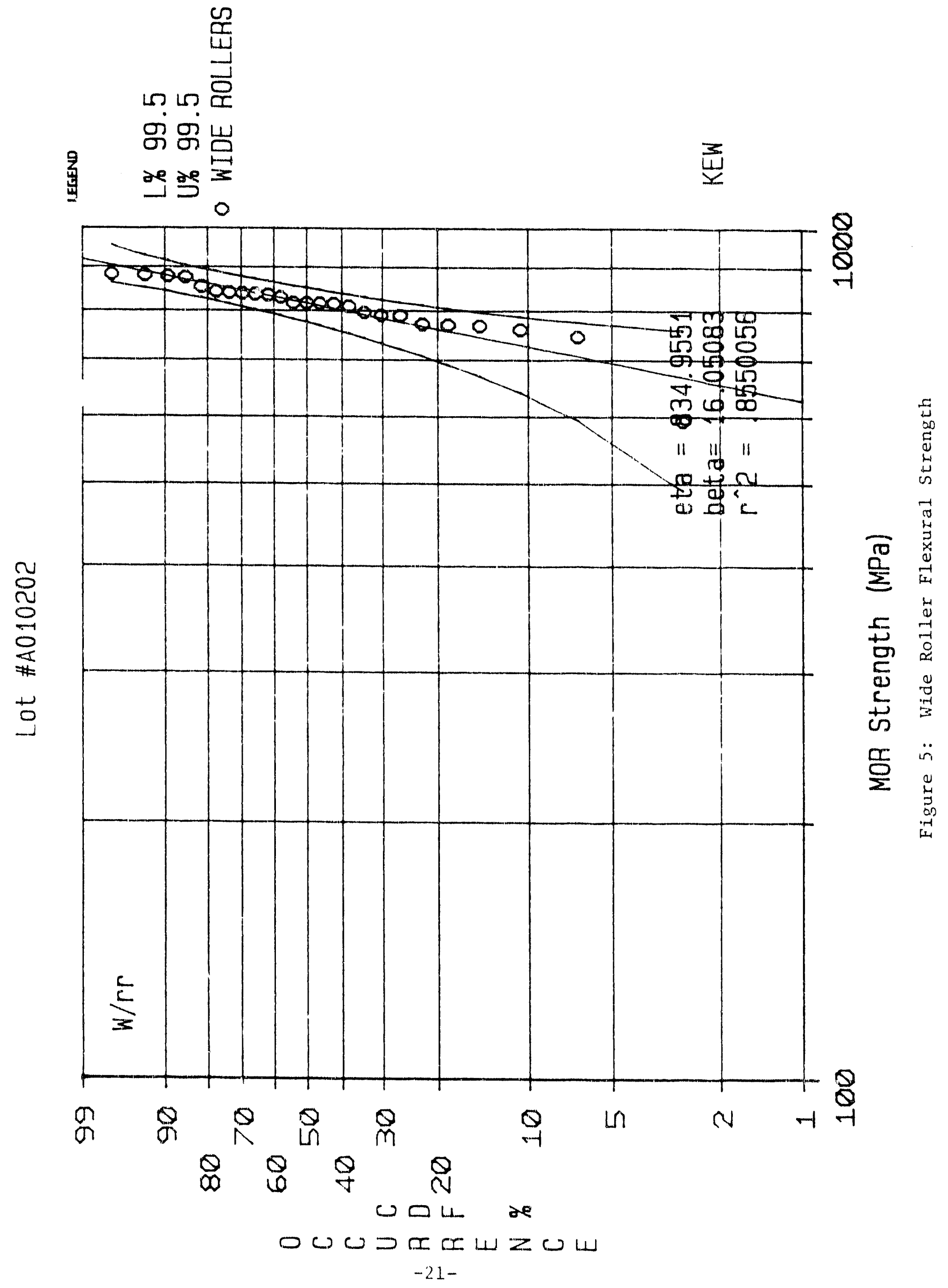




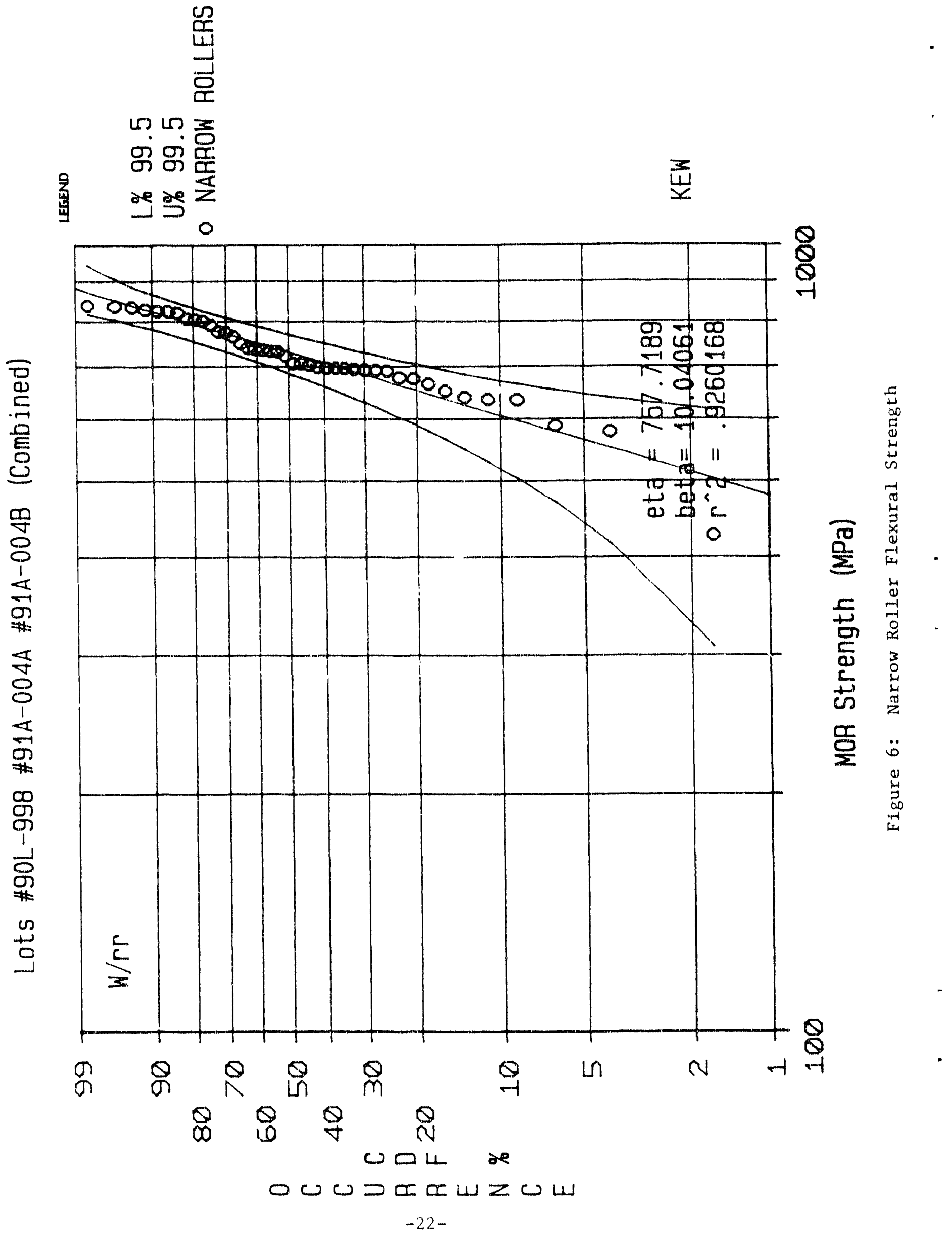




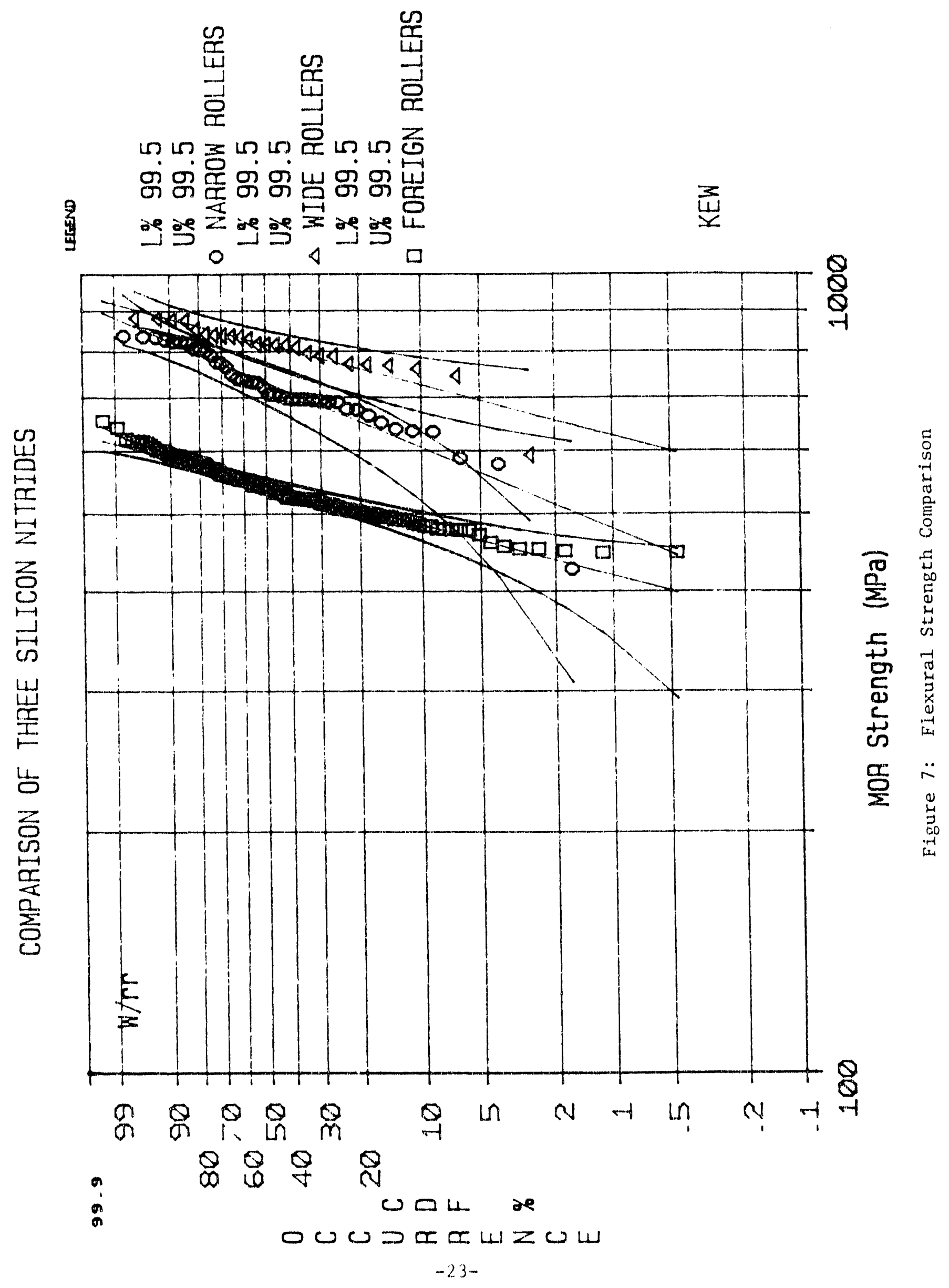




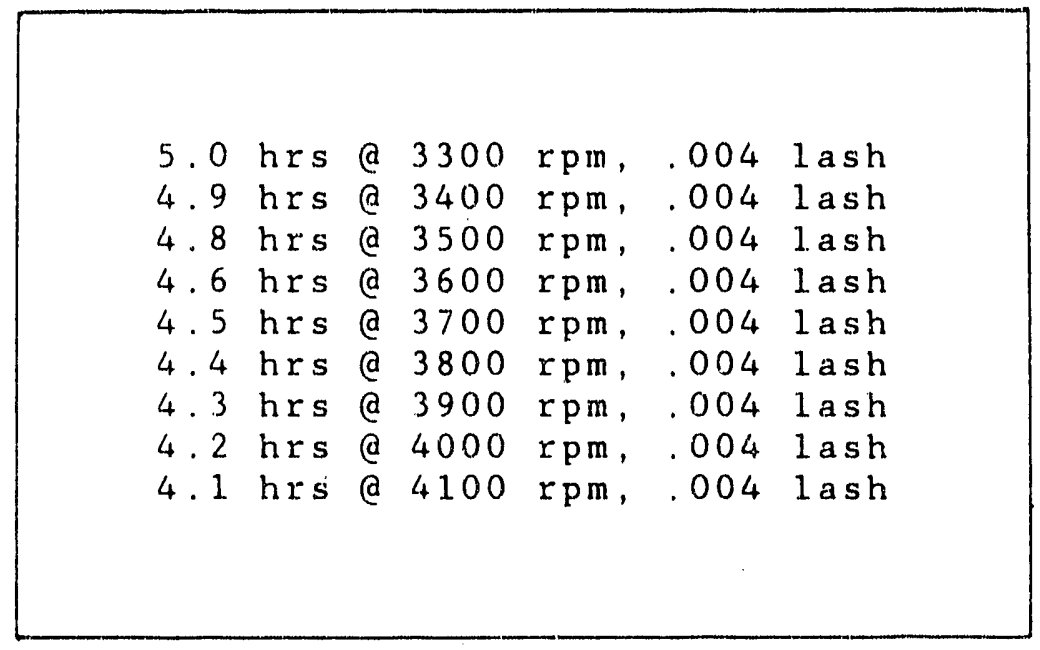

Figure 8. Overspeed Capability Test 


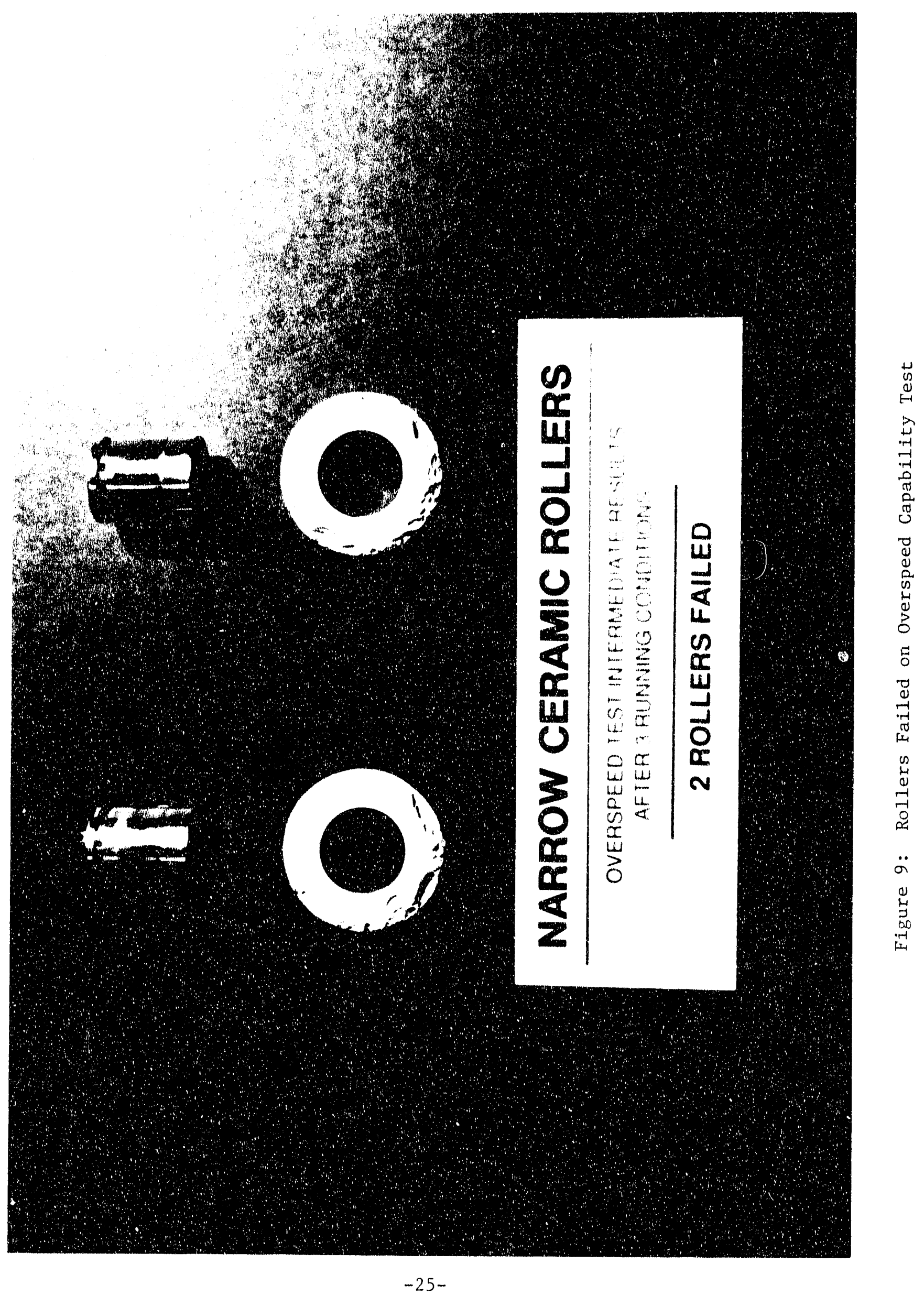


Fixture is run on the following cycle 7 times:

1 minute at $600 \mathrm{cam}-\mathrm{rpm}$, no oil pressure, room temperature oil, idle injection load

5 minutes at 600 cam-rpm, 10 psi oil pressure, room temperature oil, idle injection load

32 hours at $600 \mathrm{cam}-\mathrm{rpm}, 30 \mathrm{psi}$ oil pressure, $230^{\circ} \mathrm{F}$ temperature, full injection load

12-14 hours shutdown for oil drain and inspection

Figure 10. Accelerated wear-out test 


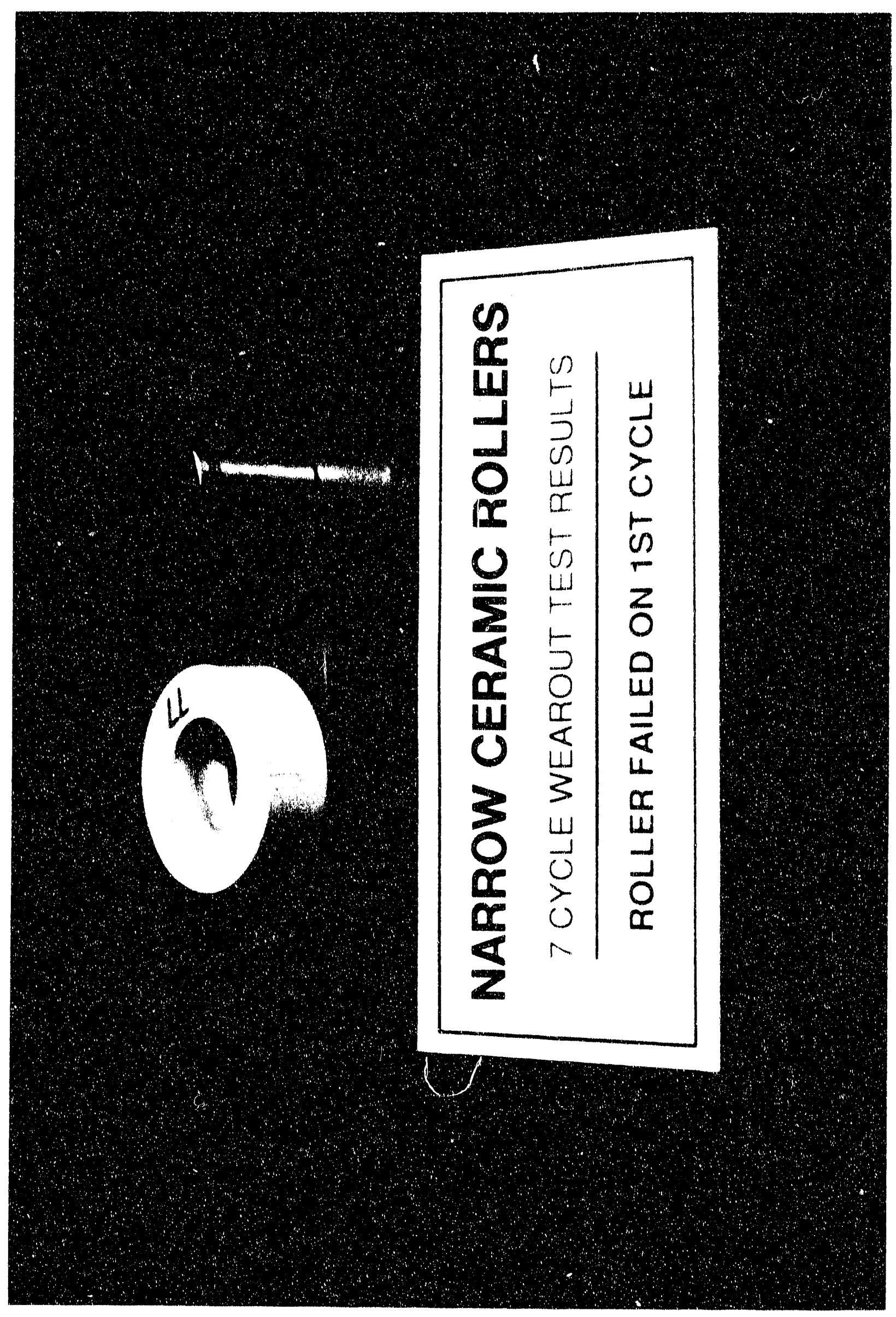

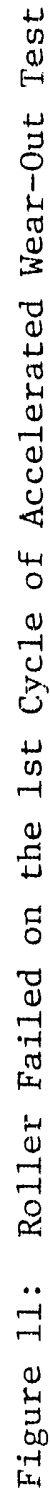




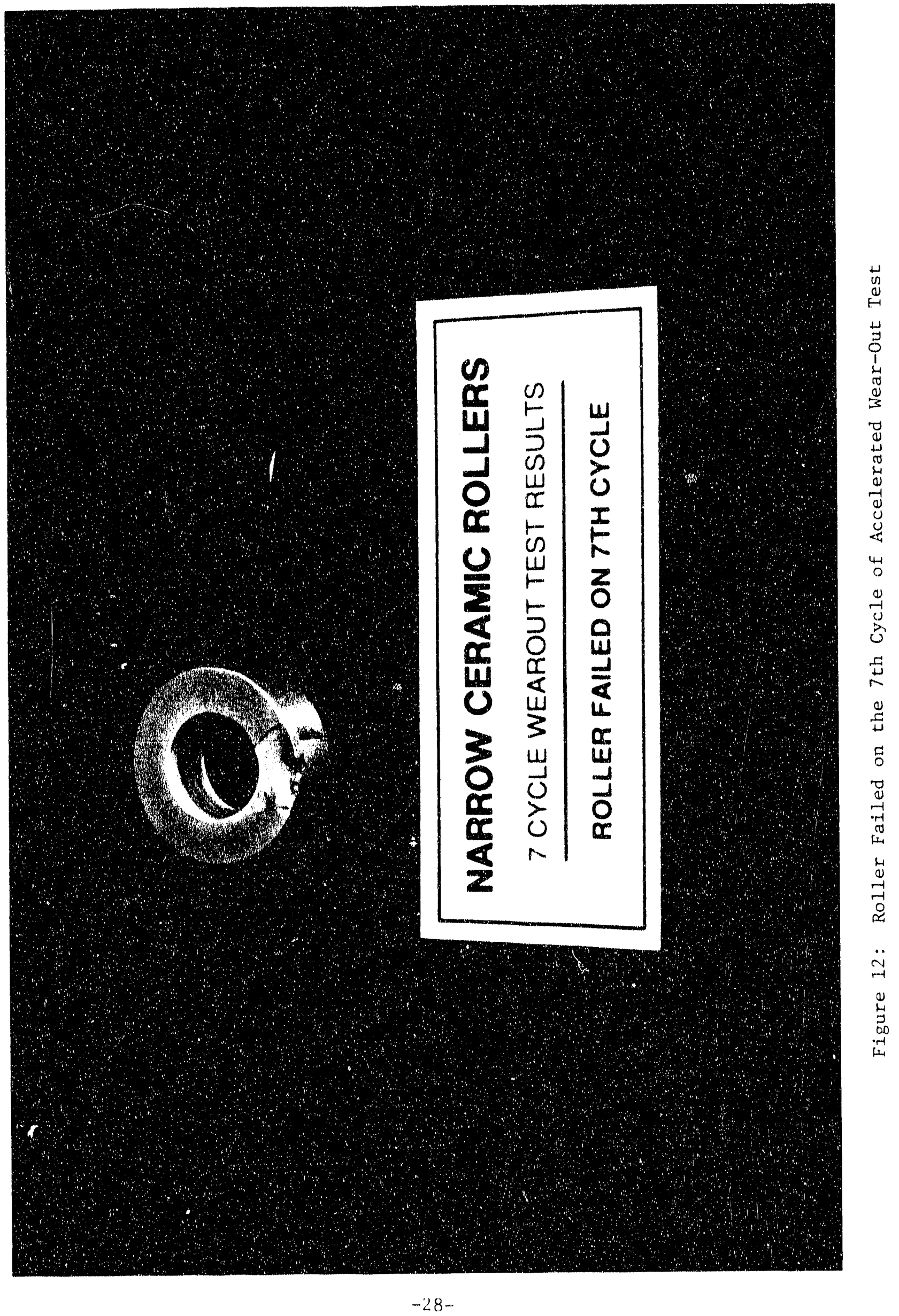




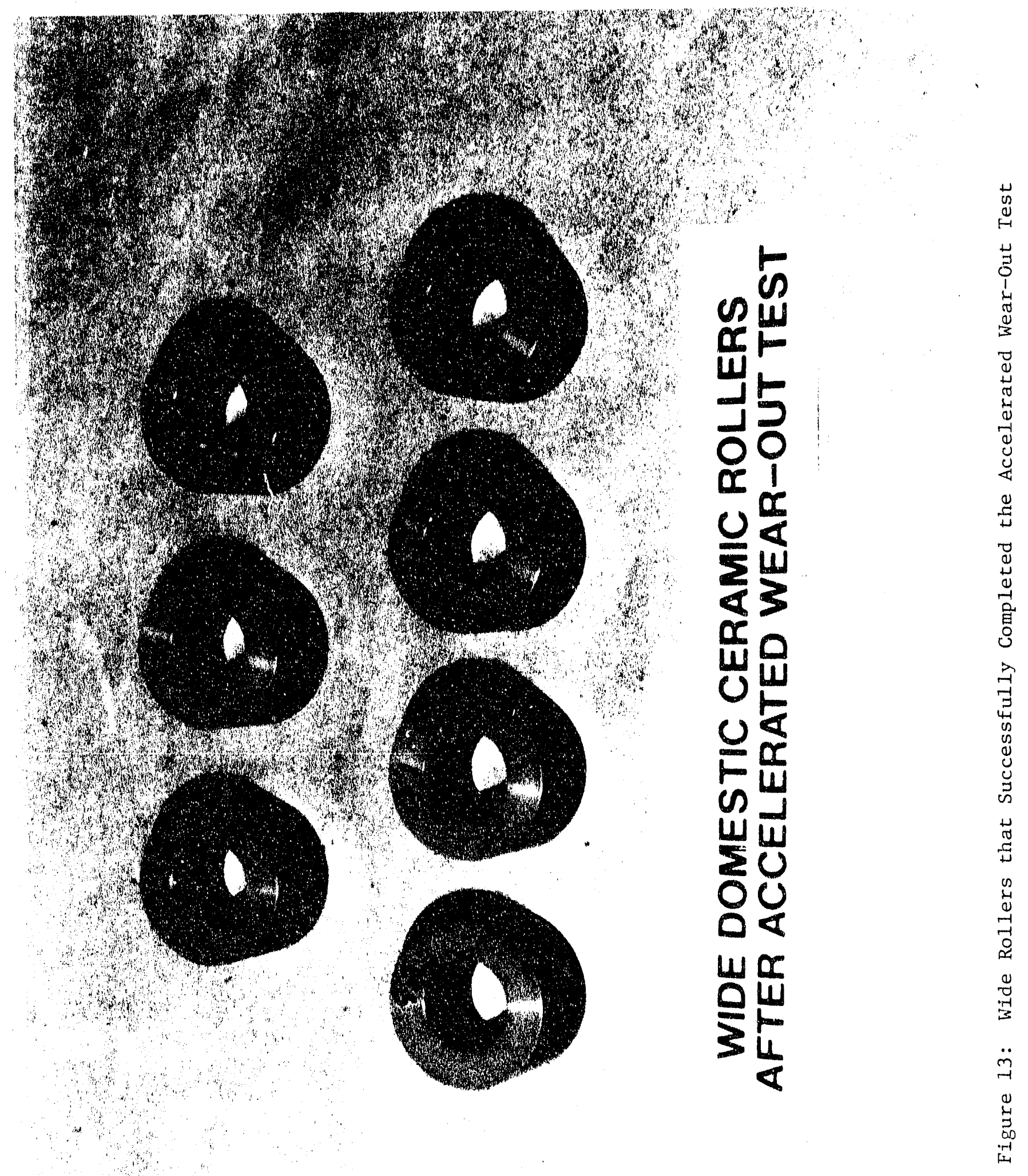



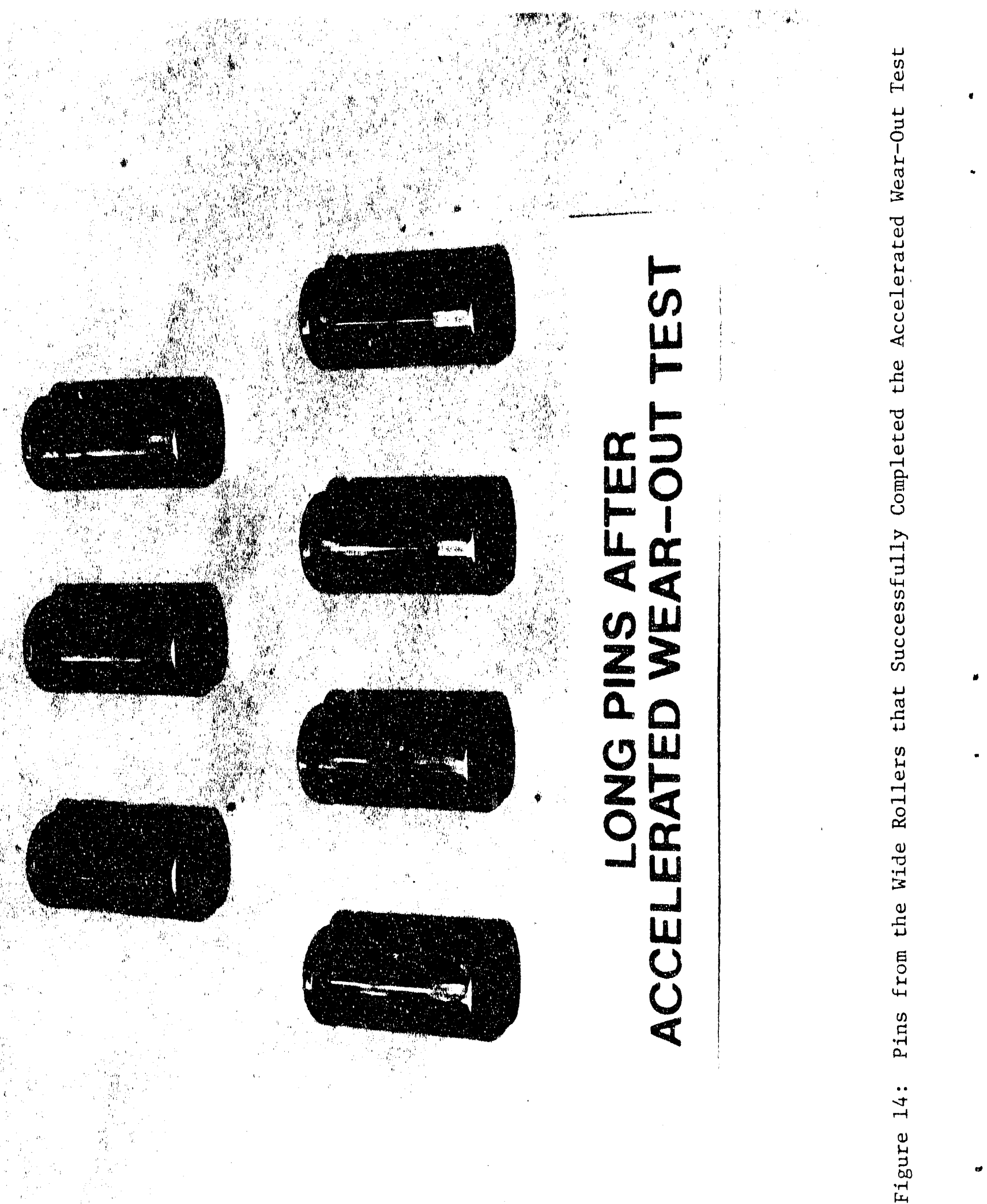


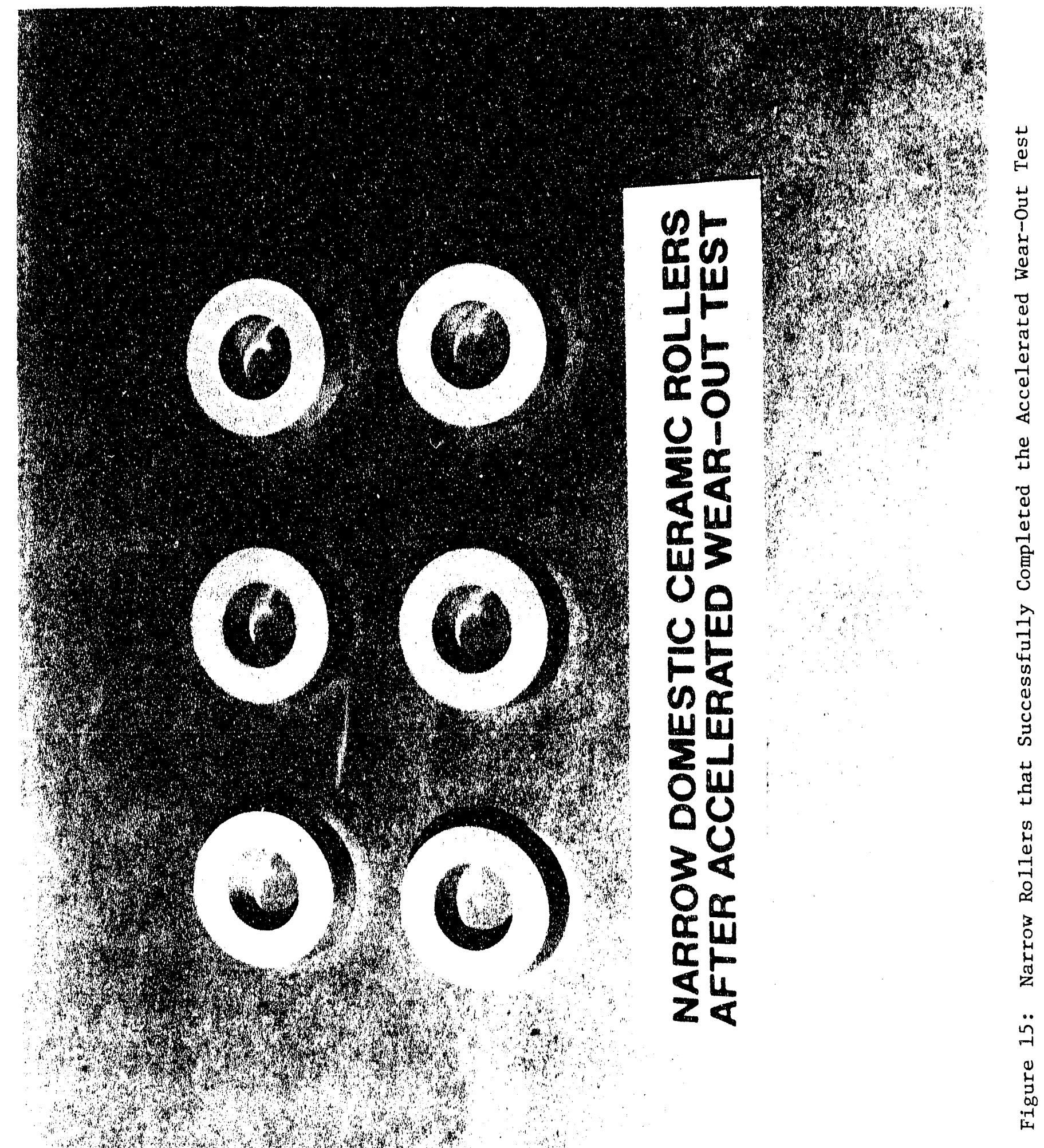




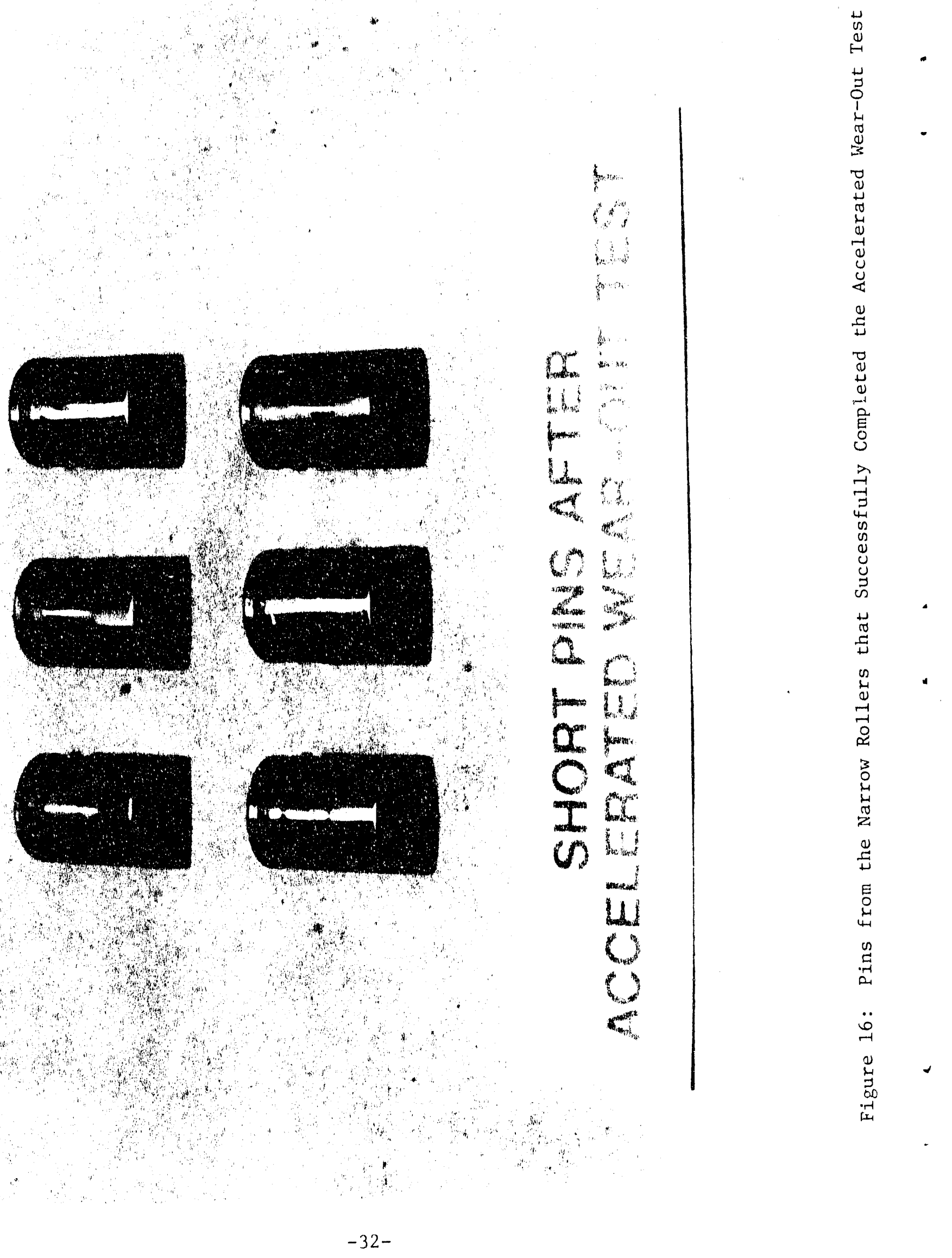




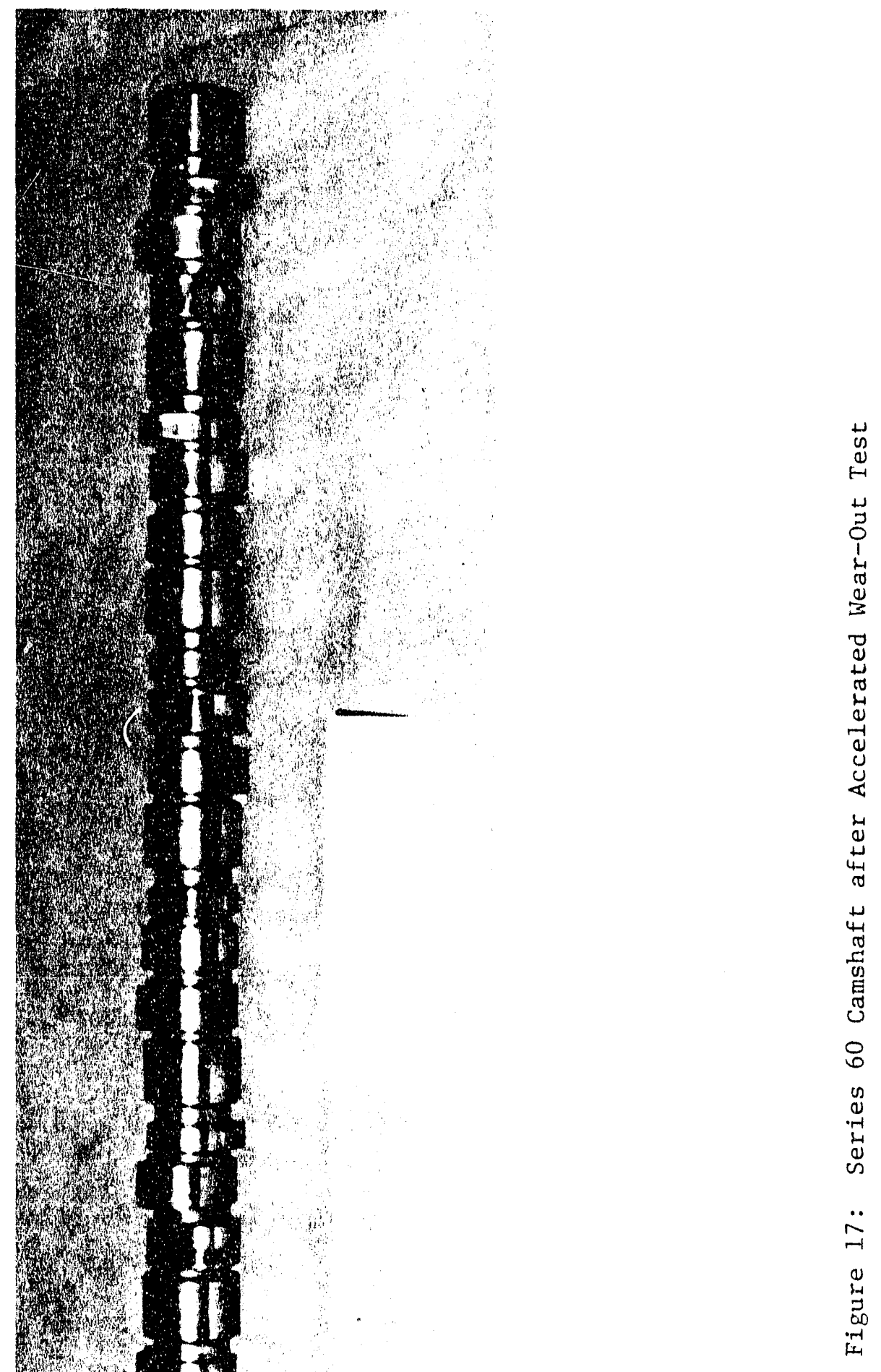



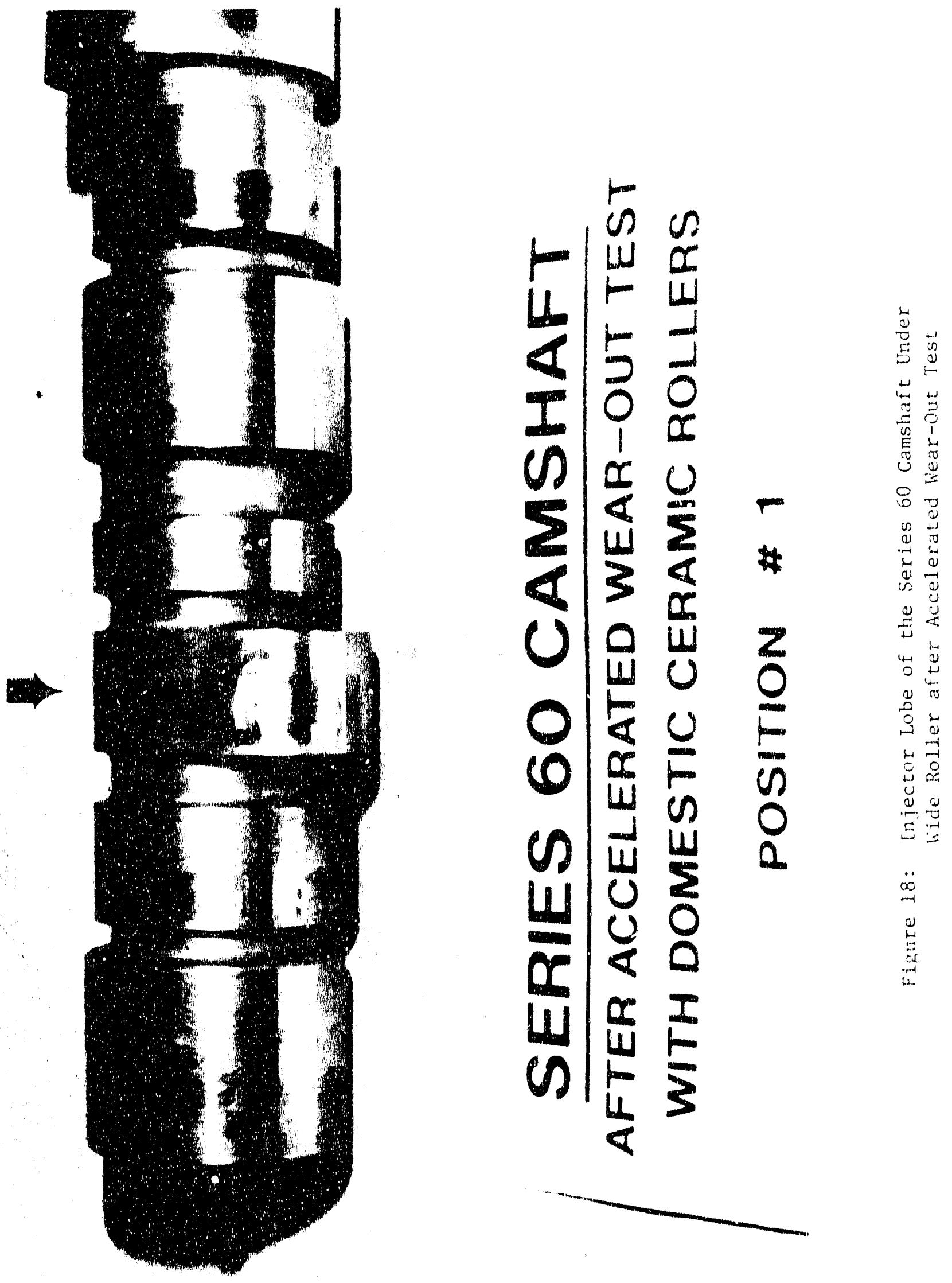


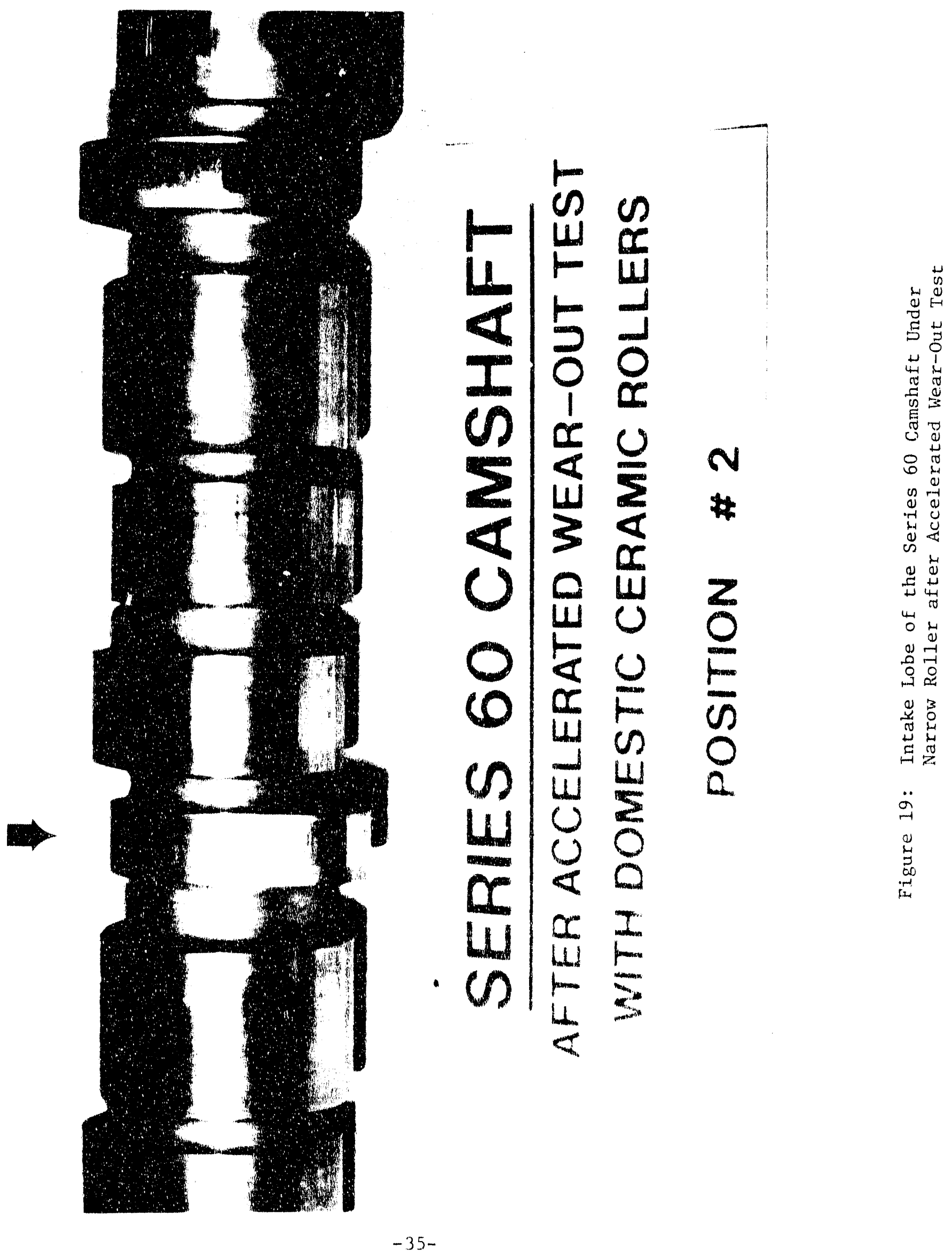




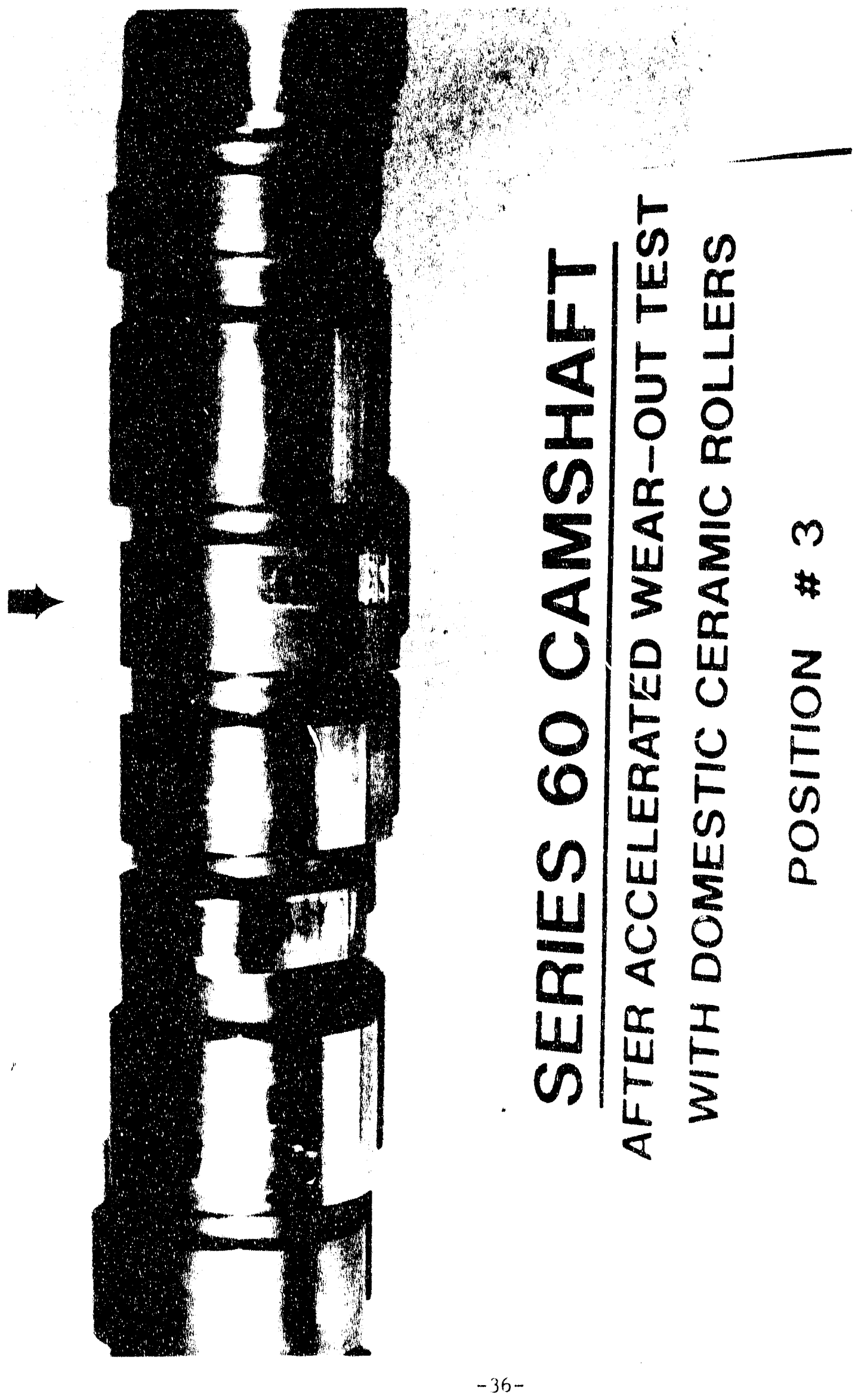

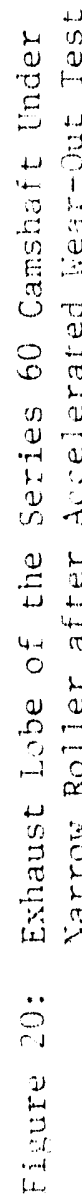




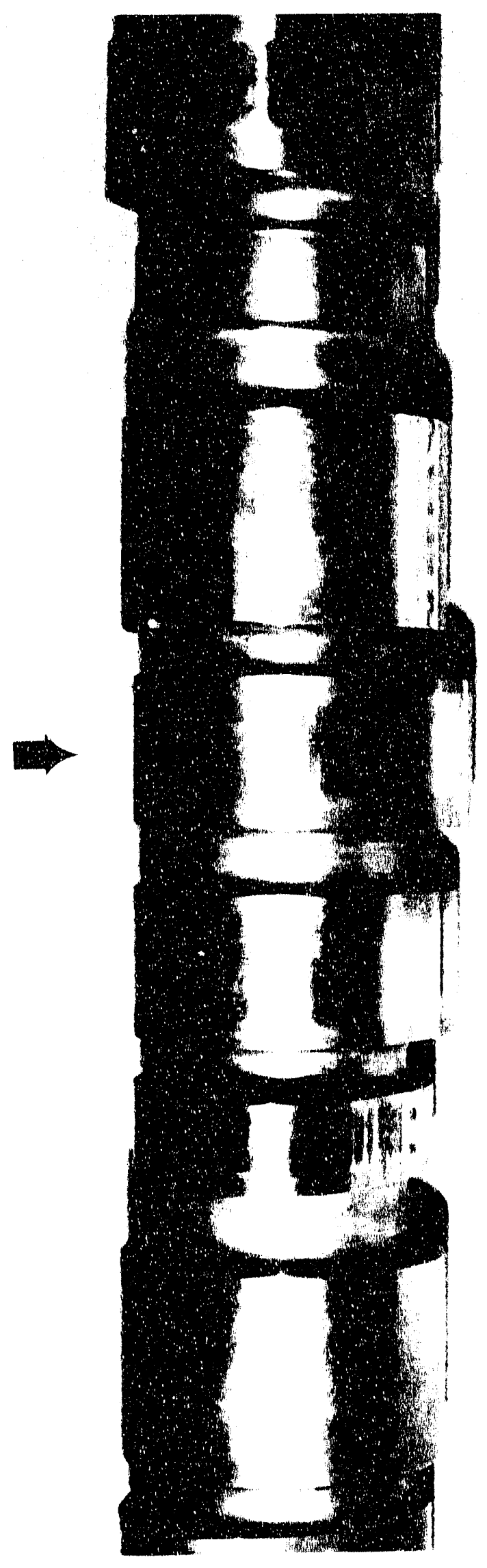

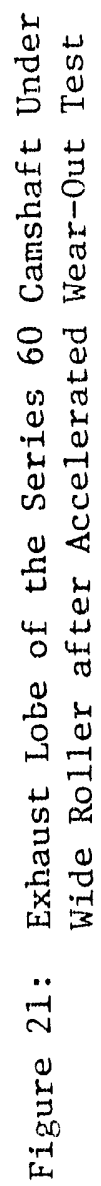



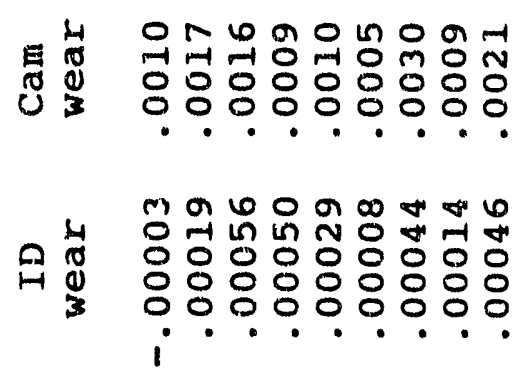

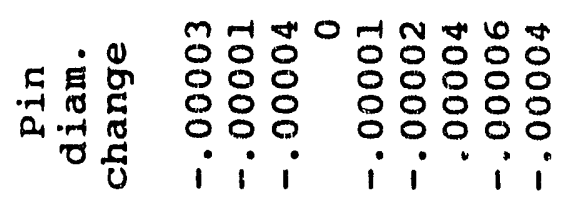

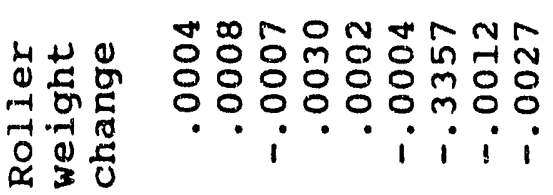

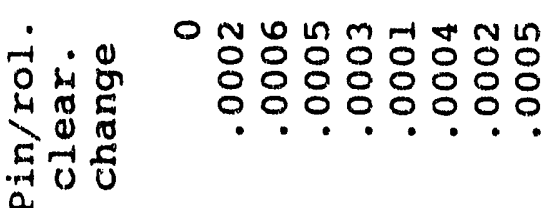

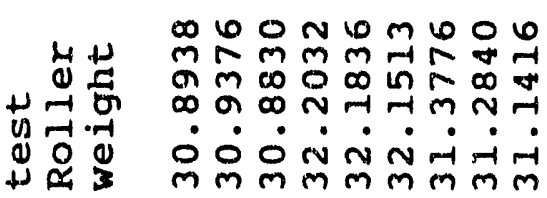

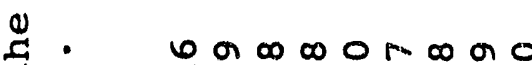

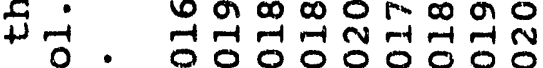

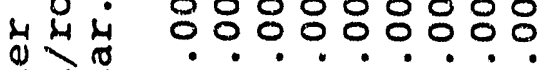

+ $E$ O

4.

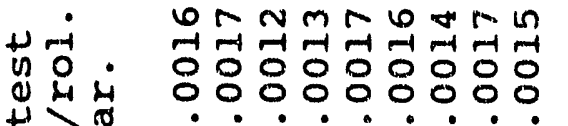

Q)

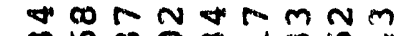

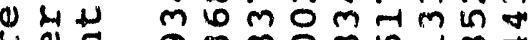

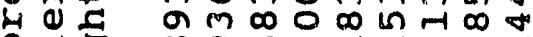

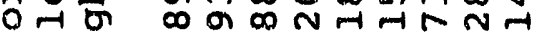

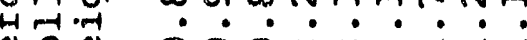

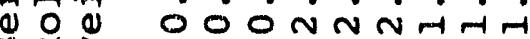

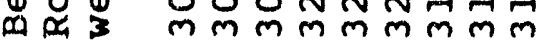

inc a 0 क

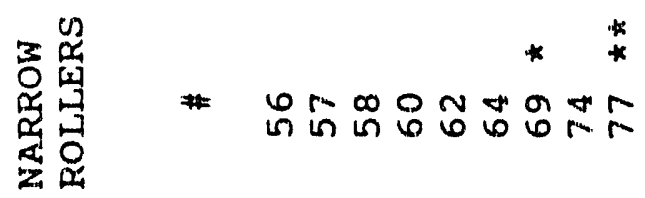

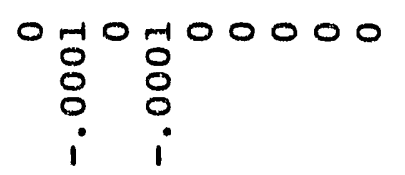

No 0000 in $N$

$0 \mathrm{~m} M \mathrm{~m} N \mathrm{O}$

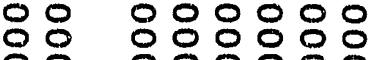

๑. ㅇ․ㅇ․․

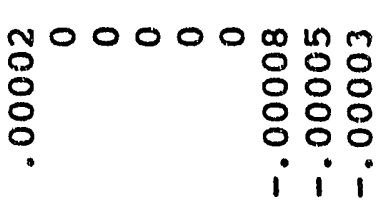

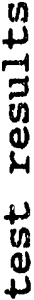

$\mathrm{N} n \mathrm{~N} n \mathrm{~mm} \mathrm{~m} \mathrm{~m}$

m NoO $000 \mathrm{NO}$

000000000

0000000000

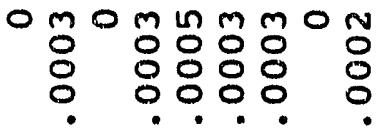

$6 m$ un on $N \infty \mathrm{m}$

$\infty m+\infty n+\infty$ n $\mathrm{moON}$ a n $\mathrm{N}$ \% $m m m N m N$ N

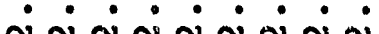

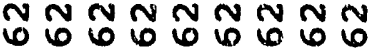

a 0 co 0 o a $\infty \infty_{1} 0$ m $N$ m $N$ N

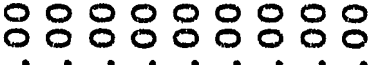

a $m \infty n$ in 0 in $\infty$ m $\circ \circ \% \circ \% \circ: \circ$

11

* $\stackrel{*}{*}$

a domo oo an $0 \infty N \rightarrow \infty n N N N$

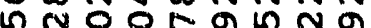
m $m$ m $\mathrm{N}-\mathrm{N} N \mathrm{~N}$ ن กิ

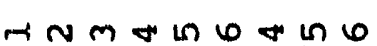

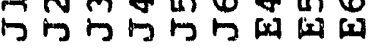

$\frac{4}{-1}$



倠

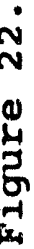

옹

$\infty$ n a moroc in $m$ क क ष क ब 


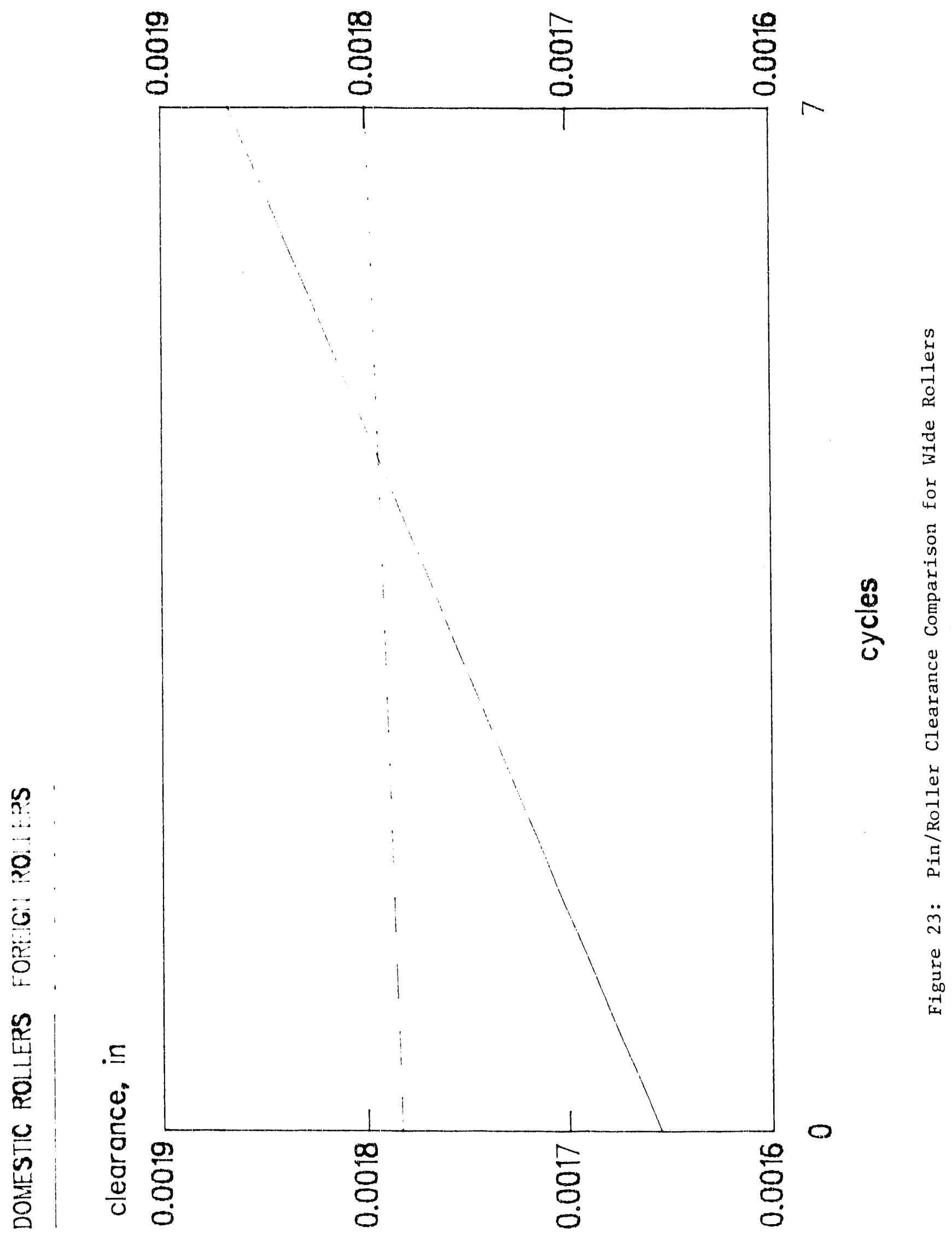




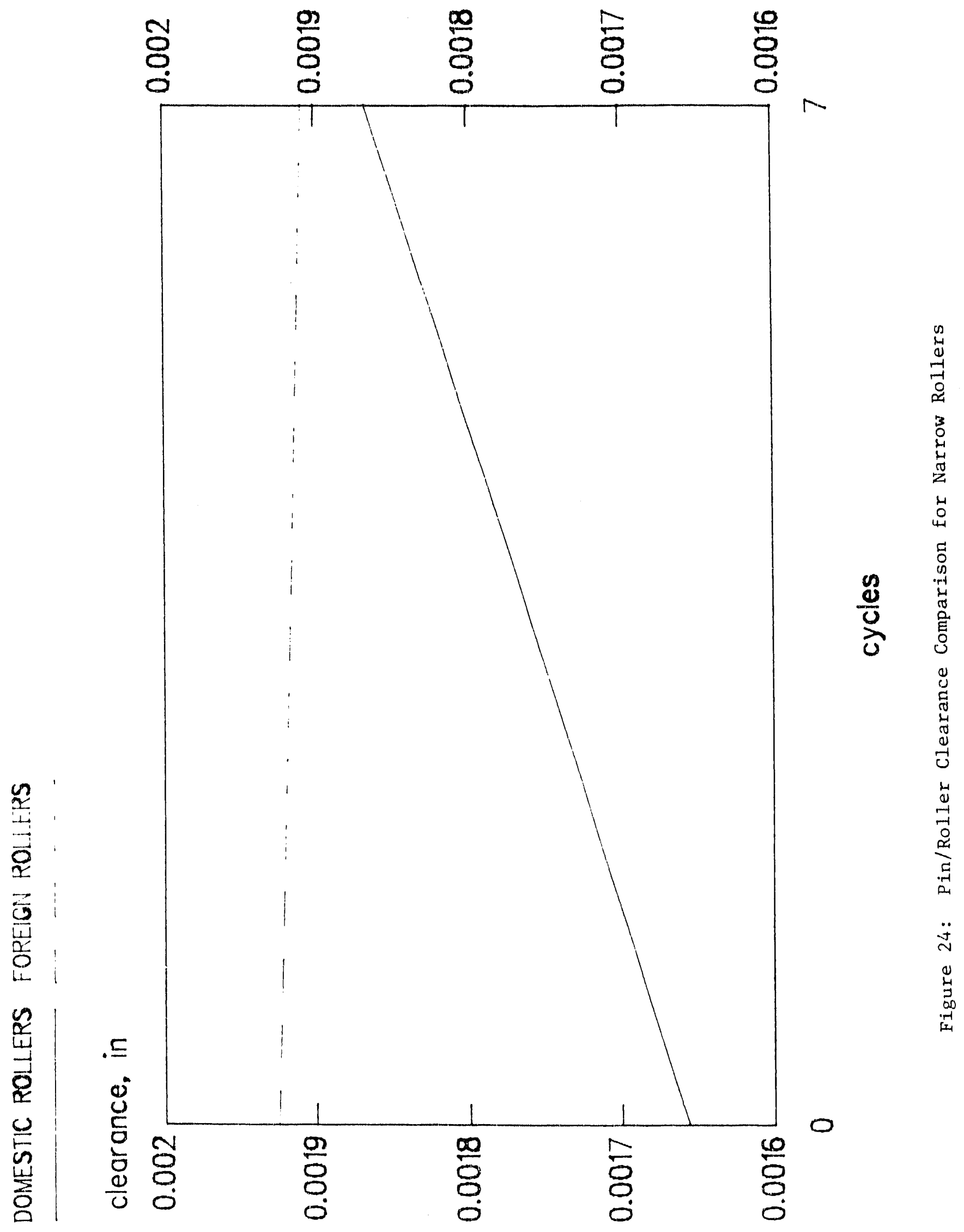




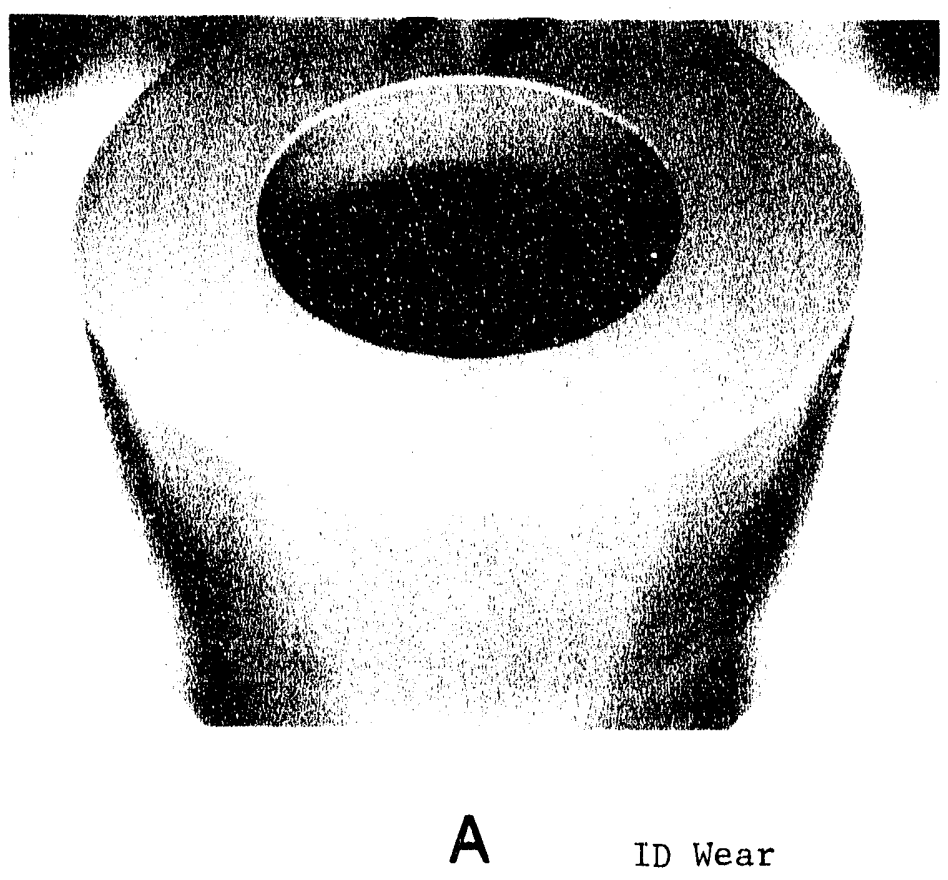

*

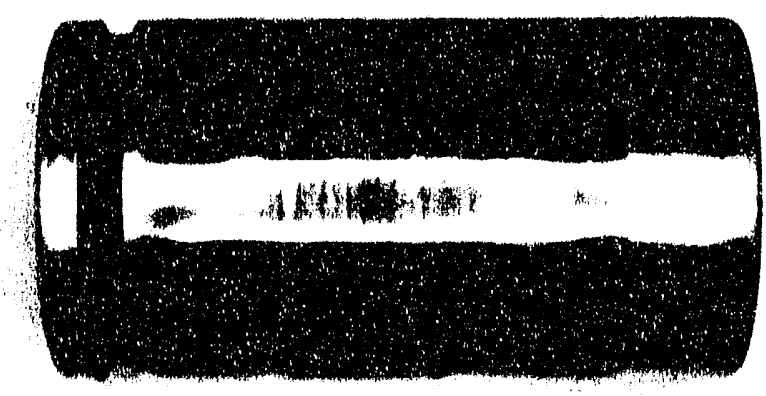

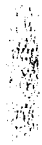

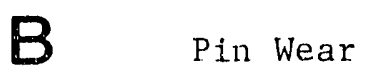

Figure 25: Wide Roller $\$ 77$ Wear 


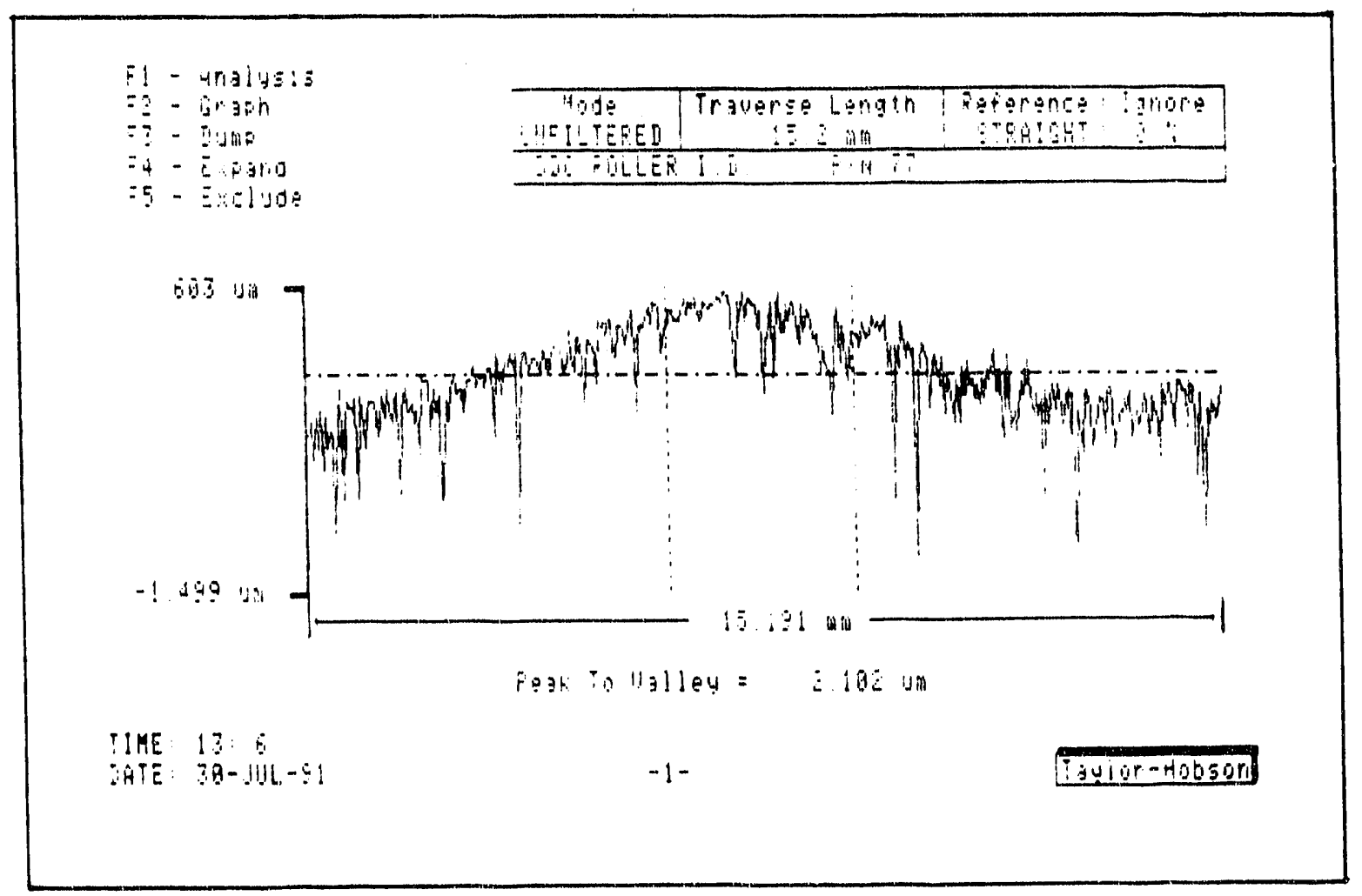

Figure 26: ID Surface Trace on the Wide Roller $\$ 77$ 


$$
\begin{aligned}
& \because \text { - inglus1 } \\
& \because-\because 30 n \\
& \because \vdots-\Sigma \text { JAO } \\
& \therefore \text { - E farr } \\
& \therefore \quad \vdots: ! 3 \text { ? }
\end{aligned}
$$

\begin{tabular}{|c|c|c|c|}
\hline 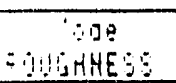 & 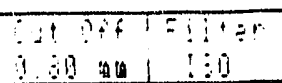 & $\begin{array}{r}\text { storence } \\
\text { OEHILHi }\end{array}$ & ?n: \\
\hline RI:L- & 4 & $E-\bar{T}$ & \\
\hline
\end{tabular}

$\therefore+110$

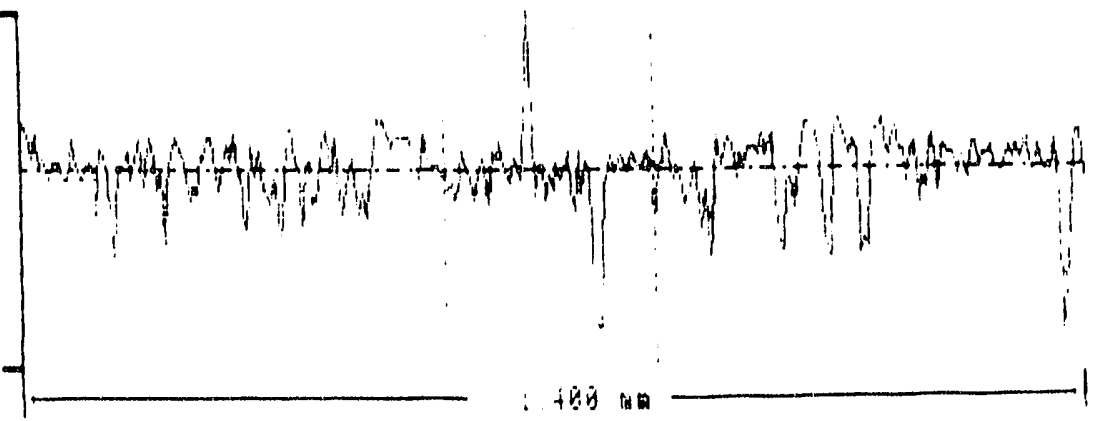

:

$\because \cdots \quad: j \quad i c$

\begin{tabular}{|c|c|}
\hline$y_{j}$ & 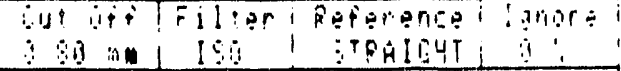 \\
\hline & $F \cdot 11$ \\
\hline
\end{tabular}

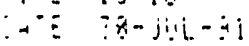

$\because-4 n j 14: 1=$

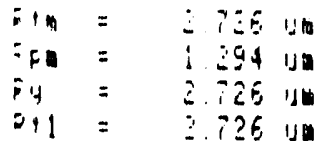

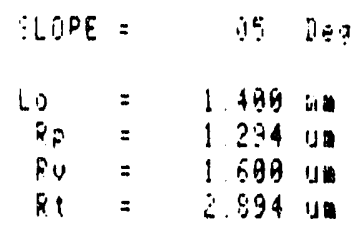

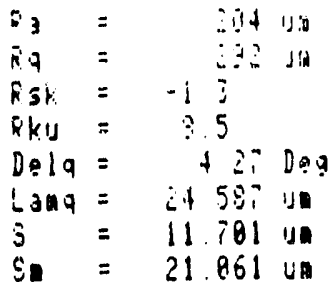

Figure 27: ID Surface Finish Near Edge of the Wide Roller \#77 


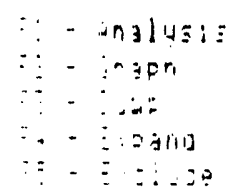

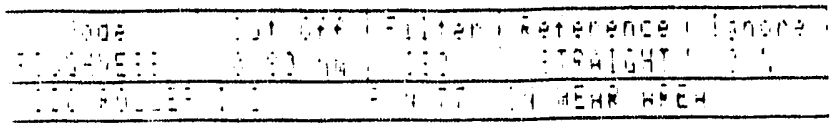

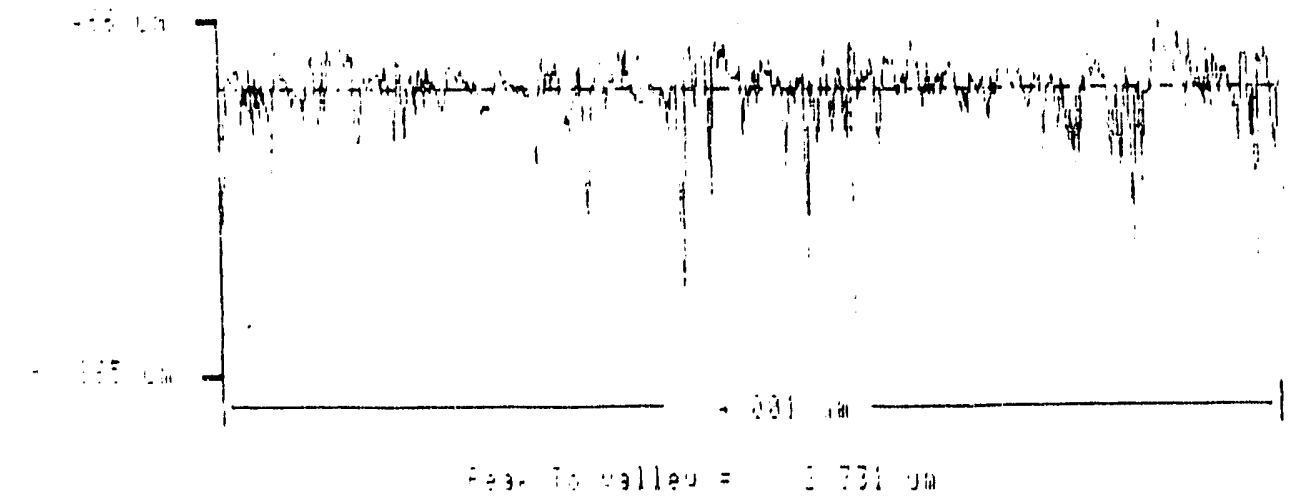

$\because \because z \quad: \because 3$

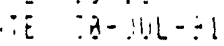

$\therefore-n_{j} j+\vdots 1 \vdots$

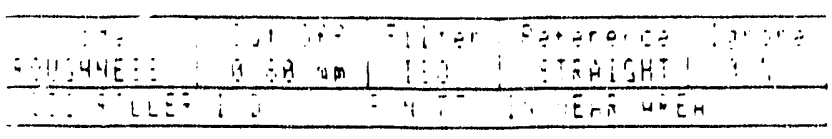

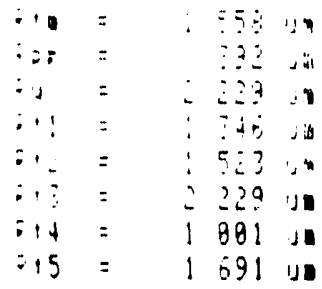

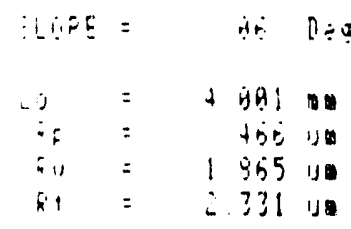

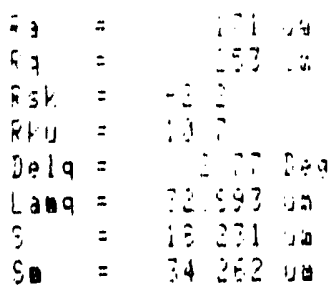

Finure 28: TD Surface finish Near the Center of the wide Roller $\$ 77$ 

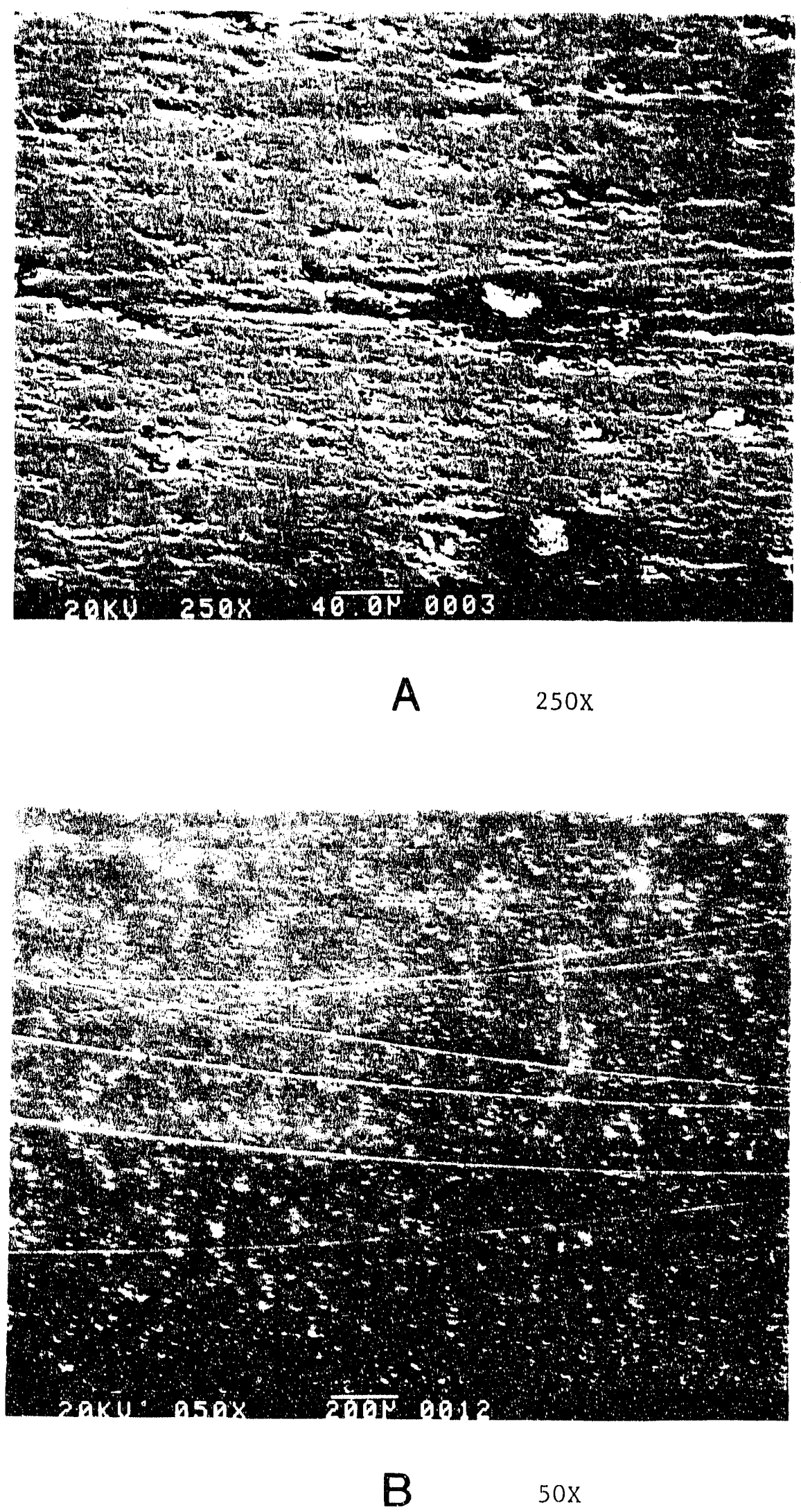

Figure 29: Photomicrographs of the Wide Roller ID Wear $-45-$ 

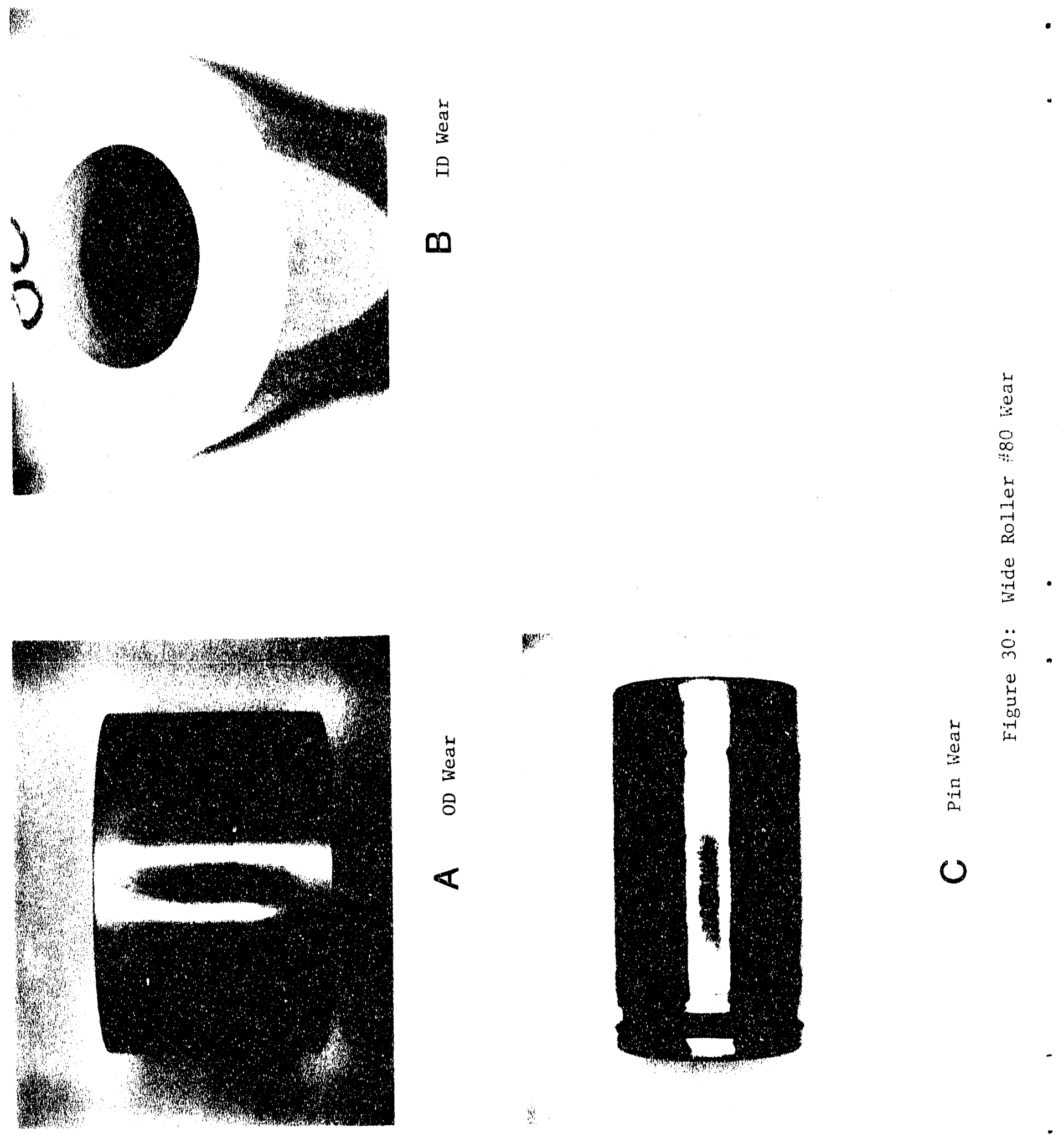


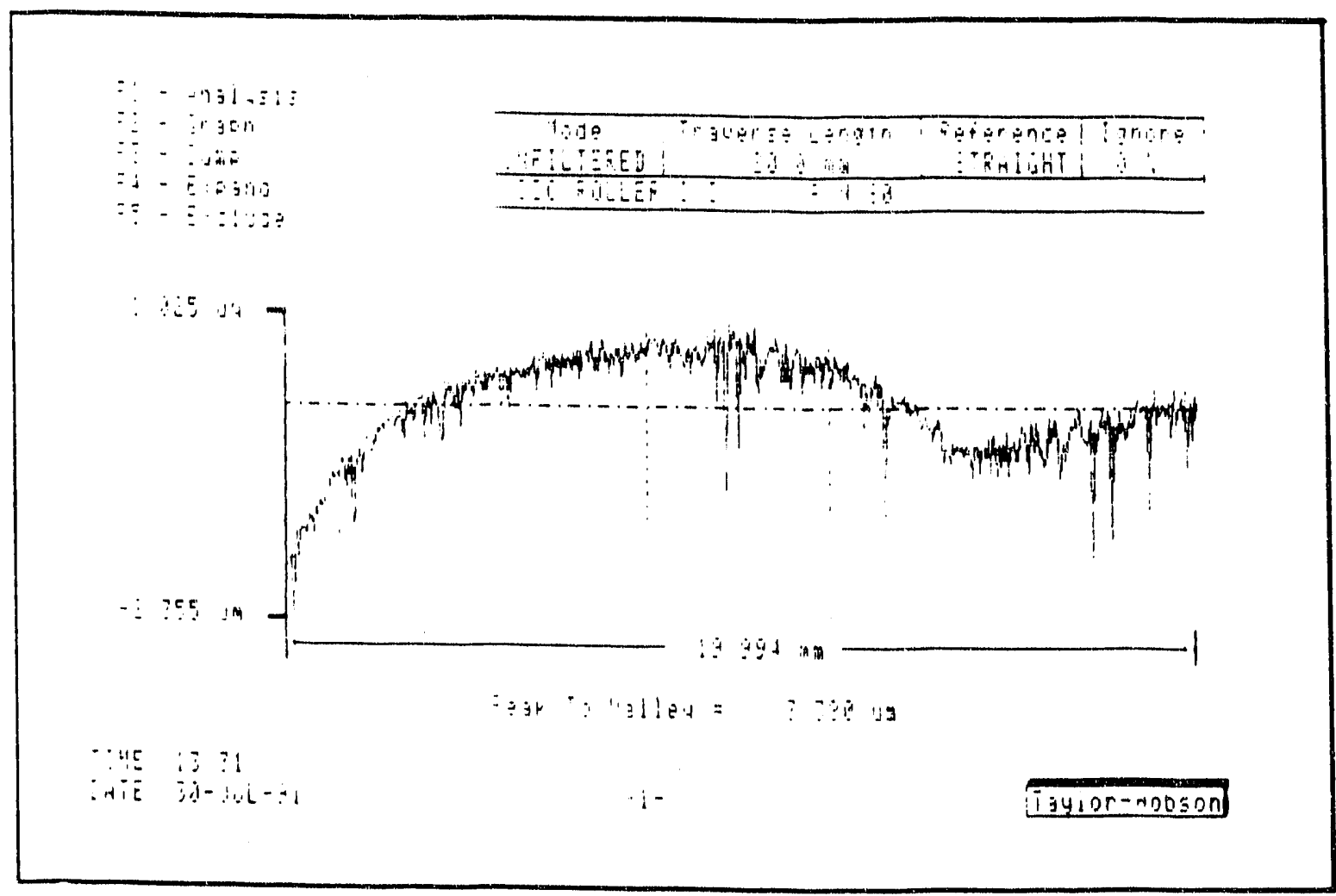

Figure 31: TD Surface Trace on the wide Roller $\$ 80$ 


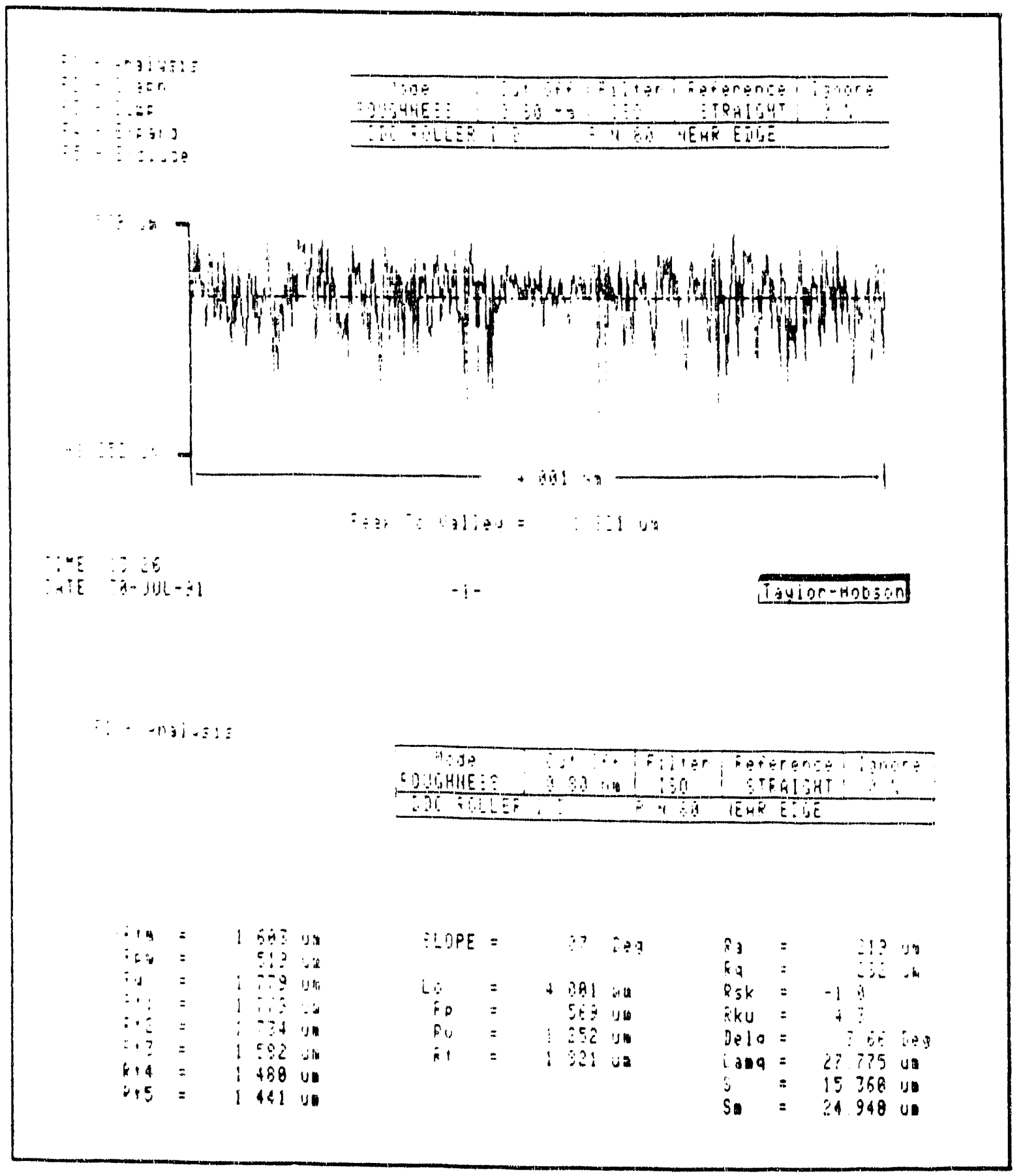

Figure 32: Il) Surface Finish Near Ecige of the Wide Roller $\$ 80$ 
$\because \vdots-a \operatorname{lolyz}=$

$\because \vdots-\because j 0 r_{1}$

$\because-3 u_{0}=$

$\therefore$ - Zloju

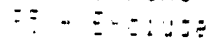

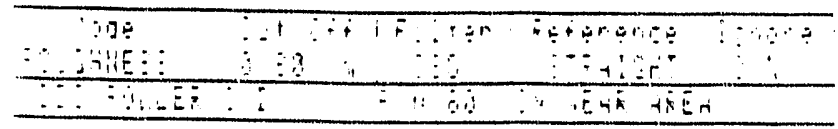

$\therefore \quad \therefore 7$

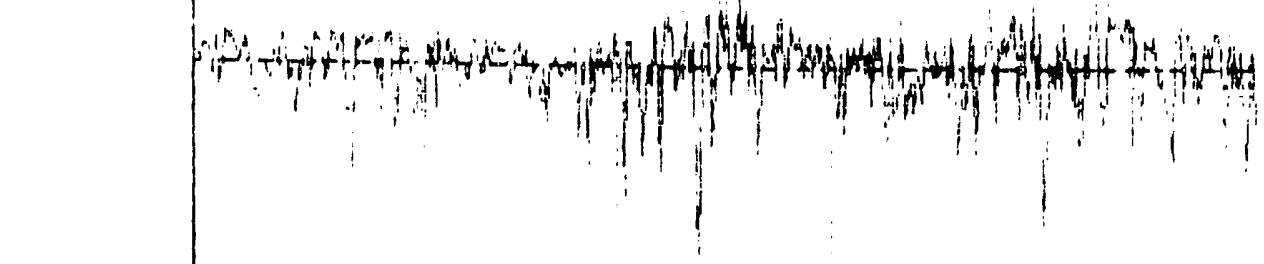

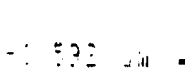

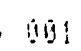

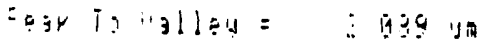

$\because \because E \quad \because \because 2$

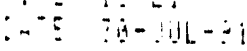

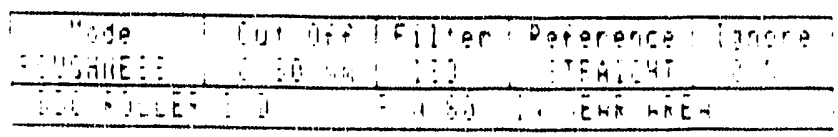

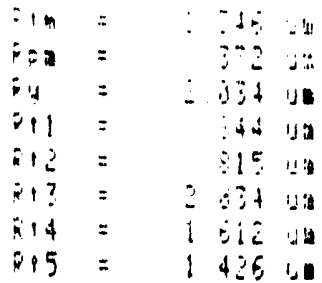

\begin{tabular}{|c|c|c|c|}
\hline$\therefore$ & $=$ & 1 & मूं \\
\hline Eo & $=$ & & to? \\
\hline (B) & $=$ & $\mathrm{i}$ & 592 \\
\hline$\therefore$ & $=$ & 2 & 395 \\
\hline
\end{tabular}

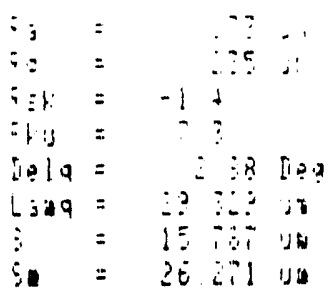

Figure 33: ID Surface Finish Near the Center of the Wide Roller $\$ 80$ 

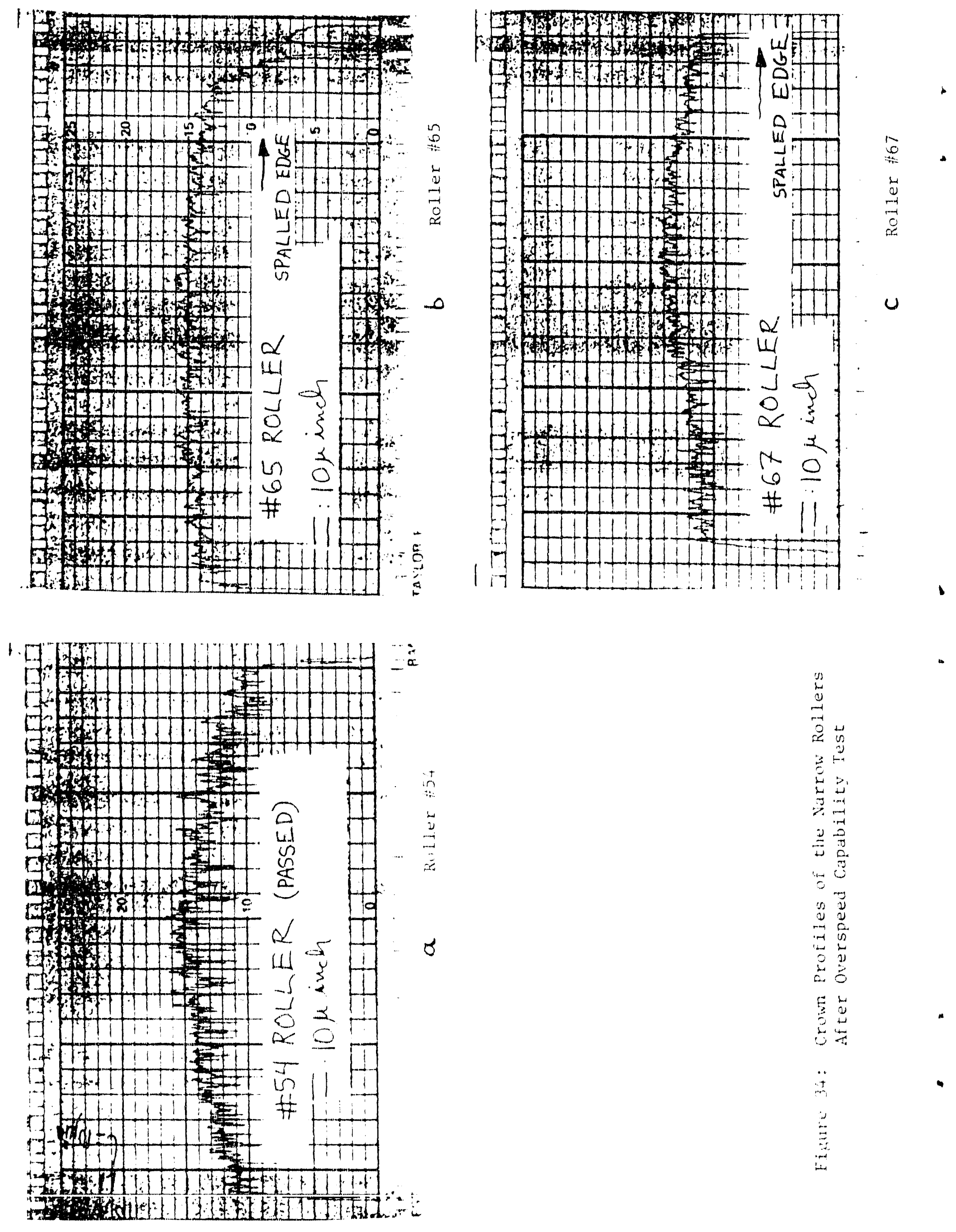

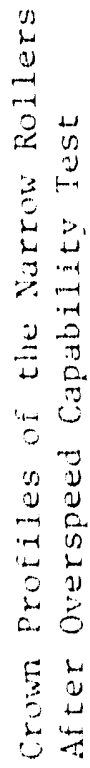



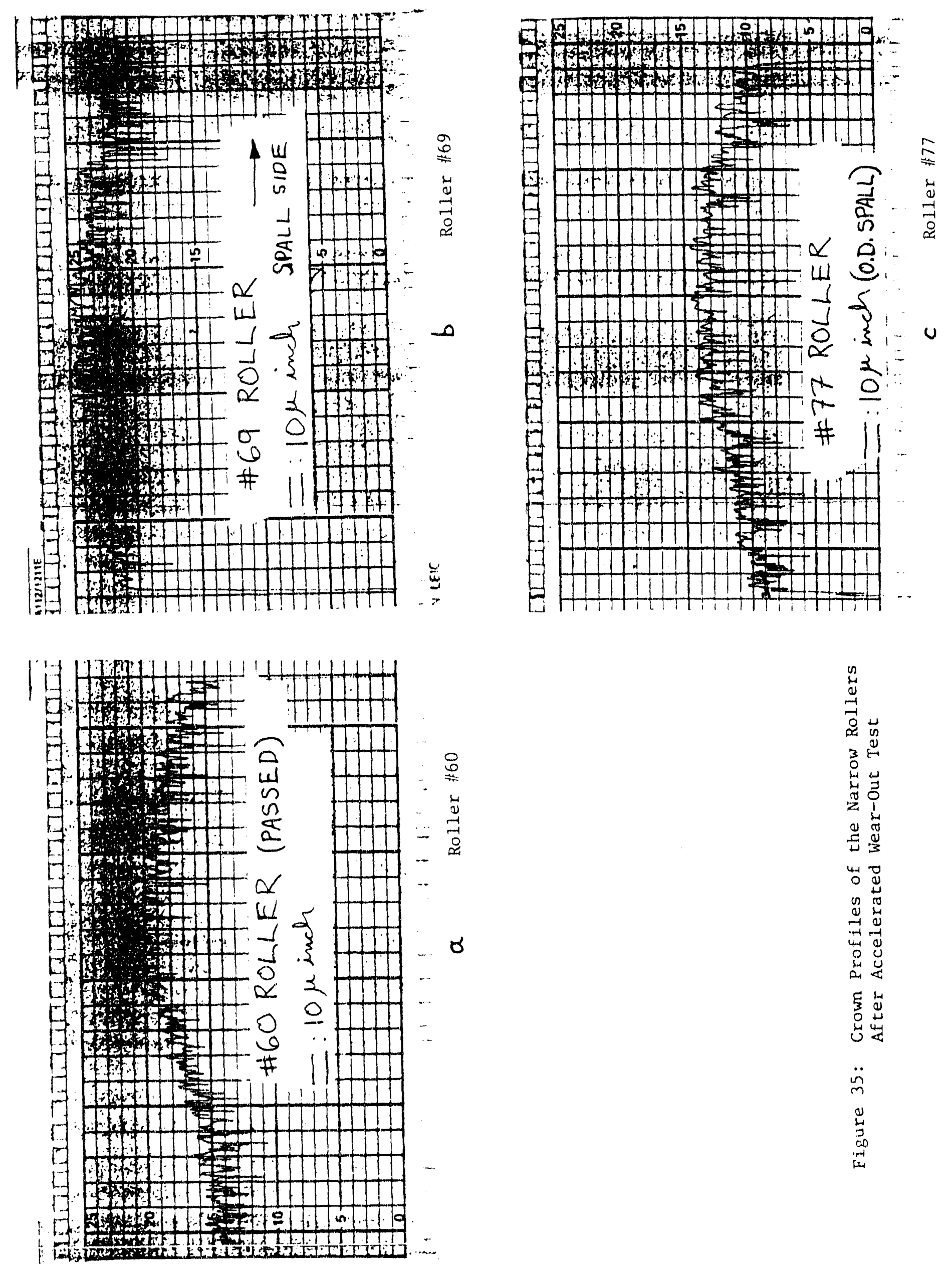
1-2. Central Research Library

3. Document Reference Section

4-5. Laboratory Records Department

6. Laboratory Records, ORNL RC

7. ORNL Patent Section

8-10. M\&C Records Office

11. L. F. Allard, Jr.

12. L. D. Armstrong

13. P. F. Becher

14. R. F. Bernal

15. T. M. Besmann

16. P. J. Blau

17. A. Bleier

18. E. E. Bloom

19. K. W. Boling

20. R. A. Bradley

21. C. R. Brinkman

22. V. R. Bullington

23. R. S. Carlsimith

24. P. T. Carlson

25. G. M. Caton

26. S. J. Chang

27. R. H. Cooper, Jr.

28. B. L. Cox

29. D. F. Craig

30. S. A. David

31. J. H. DeVan

32. J. L. Ding

33. M. K. Ferber

34. F. M. Foust

35. W. Fulkerson

36. R. L. Graves

37. D. L. Greene

38. M. H. Harris

39. E. E. Hoffman

40. C. R. Hubbard

41. M. A. Janney
42. M. G. Jenkins

43. D. R. Johnson

44. W. F. Jones

45. D. Joslin

46. R. R. Judkins

47. M. A. Karnitz

48. M. R. Kass

49-53. B. L. P. Keyes

54. H. D. Kimrey, Jr.

55. T. G. Kollie

56. K. C. Liu

57. E. L. Long, Jr.

58. W. D. Maniy

59. R. W. MCClung

60. D. J. McGuire

61. J. R. Merriman

62. D. L. Moses

63. T. A. Nolan

64. A. E. Pasto

65. J. L. Rich

66. C. R. Richmond

67. J M Robbins

68. M. L. Santella

69. A. C. Schaffhauser

70. S. Scott

71. G. M. S7aughter

72. E. J. Soderstrom

73. D. P. Stinton

74. R. W. Swindeman

75. V. J. Tennery

76. T. N. Tiegs

77. J. R. Weir, Jr.

78. B. H. West

79. F. W. Wiffen

80. S. G. Winslow

81. J. M. Wyrick

82. C. S. Yust 
83. James $H$. Adair

University of Florida

Materials Science and

Engineering

317 MAE Bldg.

Gainesville, FL 32611-2066

84. Donald F. Adams

University of Wyoming

Mechanical Engineering

Department

P. O. Box 3295

Laramie, WY 82071

85. Jalees Ahmad

AdTech Systems Research, Inc.

1342 North Fairfield Road

Dayton, $\mathrm{OH} \mathrm{45432-2698}$

86. Yoshio Akimune

NISSAN Motor Co., Ltd.

Materials Research Laboratory

1 Natsushima-Cho

Yokosuka 237

JAPAN AIR MAIL

87. Mufit Akinc

Iowa State University

322 Spedding Hall

Ames, IA 50011

88. IThan A. Aksay

University of Washington

Materials Science and Engineering

Department, FB-10

Seattle, WA 98195

89. R. G. Alexander

BASE

26 Malvern Close

Kettering Northants NN16 AJP

UNITED KINGDOM AIR MAIL

90. Richard L. Allor

Ford Motor Company

Material Systems

Reliability Department

20000 Rotunda Drive

P.0. Box 2053, Room S-2031

Dearborn, MI 48121-2053
91. Richard T. Alpaugh

U.S. Department of Energy

Advanced Propulsion Division CE-322, Forrestal Building

Washington, DC 20585

92. Joseph E. Amaral

Instron Corporation

Corporate Engineering office

100 Royale Street

Canton, MA 02021

93. Edward M. Anderson

Aluminum Company of America

North American Industrial

Chemicals Division

P.0. Box 300

Bauxite, AR 72011

94. Norman C. Anderson

Ceradyne, Inc.

Ceramic-to-Metal Division

3169 Redhill Avenue

Costa Mesa, CA 92626

95. Don Anson

Battelle Columbus Laboratories

Thermal Power Systems

505 King Avenue

Columbus, $\mathrm{OH}$ 43201-2693

96. Thomas Arbanas

G.B.C. Materials Corporation

580 Monastery Drive

Latrobe, PA 15650-2698

97. Frank Armatis

3M Company

3M Center

Building 60-1N-01

St. Paui, MN 55144-1000

98. Everett B. Arnold

Detroit Diesel Corporation

Mechanical Systems Technology

13400 Duter Drive, West

Detroit, MI 48239-4001

99. Richard M. Arons

PA Consulting Group

279 Princeton Road

Hightstown, NJ 08550 
100. Bertil Aronsson

Sandvik $A B$

S-12680

Stockholm Lerkrogsvagen 19

SWEDEN AIR MAIL

101. Dennis Assanis

University of Illinois

Department of Mechanical

Engineering

1206 W. Green Street

Urbana, IL 61801

102. William H. Atwell

Dow Corning Corporation

3901 South Saginaw Road

MS: 540

Midl and, MI 48686-0995

103. V. S. Avva

North Carolina A\&T State University

Department of Mechanical Engineering

Greensboro, NC 27411

104. Patrick Badgley

Adiabatics, Inc.

3385 Commerce Drive

Columbus, IN 47201

105. Sunggi Baik

Pohang Institute of Science \& Technology

Department of Materials Science and Engineering

P.0. Box 125

Pohang 790-600

KOREA AIR MAIL

106. John M. Bailey

Caterpillar, Inc.

Technical Center

Building L

P.O. Box 1875

Peoria, IL 61656-1875

107. Bob Baker

Ceradyne, Inc.

3169 Redhill Avenue

Costa Mesa, CA 92626
108. Frank Baker

A) uminum Company of America

Alcoa Technical Center

Alcoa Center, PA 15069

109. J. G. Baldoni

GTE Laboratories Inc.

40 Sylvan Road

Waltham, MA 02254

-.

110. Clifford P. Ballard

Allied-Signal, Inc.

Ceramics Program

P.0. Box 1021

Morristown, NJ 07962-1021

111. M. Balu

Amoco Performance Products Inc.

4500 McGinnis Ferry Road

Alpharetta, GA 30202

112. B. P. Bandyopadhyay

Toyohashi University of Technology

School of Production Systems Engineering

Tempaku-Cho Toyohashi 440

JAPAN AIR MAIL

113. P. M. Barnard

Ruston Gas Turbines Limited

Metallurgical Laboratory

P. 0. Box 1

Lincoln LN2 5DJ

ENGLAND AIR MAIL.

114. Harold N. Barr

Hittman Corporation

9190 Red Branch Road

Columbia, MD 21045

115. Renald D. Bartoe

Vesuvius McDanel

510 Ninth Avenue

Box 560

Beaver Falls, PA 15010-0560

116. Donald M. Bartos

Dow Corning Corporation

Advanced Ceramics Program

Midl and, MI 48686-0995 
117. David L. Baty

Babcock \& Wilcox-LRC

P.0. Box 11165

Lynchburg, VA 24506-1165

118. Donald F. Baxter, Jr.

ASM International

Advanced Materials and

Processes

Materials Park, OH 44073-0002

119. M. Brad Beardsley

Caterpillar, Inc.

Advanced Materials Technology

Technical Center B1dg. E

P.0. Box 1875

Peoria, IL 61656-1875

120. Robert Beck

Teledyne CAE

Materials Engineering/Programs

1330 Laskey Road

P.0. Box 6971

Toledo, $\mathrm{OH} 43612$

121. John C. Bell

Shell Research Limited

Thornton Research Centre

P.0. Box 1

Chester, Chl 3SH

ENGLAND AIR MAIL

122. Albert H. Bell, III

General Motors Technical Center 30200 Mound Road

Engineering Building/W3 Turbine

Warren, MI 48090-9010

123. M. Bentele

Xamag, Inc.

259 Melville Avenue

Fairfield, CT 06430

124. Larry D. Bentsen

BF Goodrich Company

R\&D Center

9921 Brecksville Road

Brecksville, OH 44141

125. Joseph C. Bentz

ENCERATEC

2525 Sandcrest Drive

Columbus, IN 47203
126. Louis Beregszazi

Defiance Precision Products

P.0. Drawer 428

Defiance, $\mathrm{OH} 43512$

127. Tom Bernecki

Northwestern University

BIRL

1801 Maple Avenue

Evanston, It 60201-3135

128. Charles F. Bersch

Institute for Defense Analyses

1801 North Beauregard Street

Alexandria, VA 22311

129. Ram Bhatt

NASA Lewis Research Center

21000 Brookpark Road

Cleveland, OH 44135

130. Deane I. Biehler

Caterpiliar, Inc.

Engineering and Research Materials

Technical Center, Building E

P.0. Box 1875

Peoria, IL 61656-1875

131. John. W. Bjerklie

Consolidated Natural Gas

Service Co., Inc.

Research Department

CNG Tower

Pittsburgh, PA 15222-3199

132. William D. Bjorndahl

TRW, Inc.

One Space Park

Building 01, Room 2040

Redondo Beach, CA 90278

133. Keith A. Blakely

Advanced Refractory

Technologies, Inc.

699 Hertel Avenue

Buffalo, NY 14207

134. Edward G. Bl anchard

Netzsch Inc.

119 Pickering Way

Exton, PA 19341 
135. Keith $B 1$ andford

Boride Products, Inc.

2879 Aero Park Drive

Traverse City, MI 49684

136. Bruce Boardman

Deere and Company Technical

Center

3300 River Drive

Moline, IL 61265

137. Russell Bockstedt

Hoechst Celanese Corporation

150 JFK Parkway

Short Hills, NJ 07078

138. M. Boehmer

DLR German Aerospace Research Establ i shment

Postfach 906058

D.5000 Koln 90

GERMANY AIR MAIL

139. Lawrence P. Boesch

EER Systems Corp.

1593 Spring Hill Road

Vienna, VA 22182-2239

140. Donald H. Boone

Boone \& Associates

2412 Cascade Drive

Walnut Creek, CA 94598-4313

141. Tom Booth

Allied-Signal Aerospace

Company

AiResearch Los Angeles

Division

2525 West 190th Street

Torrance, CA 90509-2960

142. Tibor Bornemisza

Sundstrand Power Systems

4400 Ruffin Road

San Diego, CA 92186-5757

143. J.A.M. Boulet

University of Tennessee

Department of Engineering Science and Mechanics

310 Perkins Hall

Knoxville, TN 37996-2030
144. H. Kent Bowen

Massachusetts Institute of Technology

77 Massachusetts Avenue

Room E40-434

Cambridge, MA 02139

145. Lestie J. Bowen

Materials Systems

53 Hillcrest-Road

Concord, MA 01742

146. Steven C. Boyce

Air Force Office of

Scientific Research

AFOSR/NA Bldg. 410

Bolling AFB DC 20332-6448

147. Gary L. Boyd

CEC

400 Howell Avenue, No. 4

Warl and, WY 82401

148. Steve Bradley

UOP Research Center

50 East Algonquin Road

Des Plaines, IL 60017-6187

149. Michael C. Brands

Cummins Engine Company, Inc.

P.0. Box 3005

Mail Code 50179

Columbus, IN 47201

150. Raymond J. Bratton

Westinghouse Science and

Technology Center

1310 Beulah Road

Pittsburgh, PA 15235

151. John J. Brennan

United Technologies Corporation

Research Center

Silver Lane, MS: 24

East Hartford, CT 06108

152. Jeff D. Bright

Ceramatec, Inc.

2425 South 900 West

Salt Lake City, UT 84108 
153. Terrence K. Brog

Coors Ceramics Company

Corporate Development and Technology

4545 McIntyre Street

Golden, $\mathrm{CO} 80403$

154. Gunnar Broman

317 Fairlane Drive

Spartanburg, SC 29302

155. A1 Brown

High-Tech Materials Alert

P.0. Box 882

Dayton, NJ 08810

156. Jesse Brown

Virginia Polytechnic Institute and State University

Center for Advanced Ceramic Materials

Blacksburg, VA 24061-0256

157. Sherman D. Brown

University of 111 inois

Materials Science and

Engineering Department

105 South Goodwin Avenuse

204 Ceramics Building

Urbana, IL 61801

158. S. L. Bruner

Ceramatec, Inc.

2425 South 900 West

Salt Lake City, UT 84119

159. Adolfo Brusaferro

Keramont Corporation

4231 South Fremont Avenue

Tucson, AZ 85714

160. W. Bryzik

U.S. Army Tank Automotive Command

R\&D Center

Propulsion Systems Division

Warren, MI 48397-5000

161. S. T. BuTjan

GTE Laboratories, Inc.

40 Sylvan Road

Wart tham, MA 02254
162. S. J. Burden

GTE Valenite

1711 Thunderbird

Troy, MI 48084

163. Curt V. Burkland

AMERCOM, InC.

8928 Fullbright Avenue

Chatsworth, CA 91311

$$
\text { -. }
$$

164. Bill Bustamante

AMERCOM, Inc.

8928 Fullbright Street

Chatsworth, CA 91311

165. Oral Buyukozturk

Massachusetts Institute of Technology

77 Massachusetts Avenue

Room 1-280

Cambridge, MA 02139

166. David A. Caillet

Ethyl Corporation

451 Florida Street

Baton Rouge, LA 70801

167. Frederick J. Calnan

Heany Industries, Inc.

249 Briarwood Lane

P.0. Box 38

Scottsville, NY 14546

168. Roger Cannon

Rutgers University

Ceramics Department

P.0. Box 909

Piscataway, NJ 08855-0909

169. Scott Cannon

P.0. Box 567254

At Tanta, GA 30356

170. Harry H. Carpenter

19945 Acre Street

Northridge, CA 91324

171. David Carruthers

Kyocera Industrial Ceramics Company

P.O. Box 2279

Vancouver, WA 98668-2279 
172. Calvin H. Carter, Jr.

Cree Research, Inc.

2810 Meridian Parkway

Durham, NC 27713

173. J. David Casey

35 Atlantis Street

West Roxbury, MA 02132

174. Jere G. Castor

J. C. Enterprise

5078 North 83rd Street

Scottsdale, AZ 85250

175. James D. Cawley

Case Western Reserve University

Materials Science and

Engineering Department

Cleveland, $\mathrm{OH} 44106$

176. Thomas C. Chadwick

Den-Mat Corporation

P.0. Box 1729

Santa Maria, CA 93456

177. Ronald H. Chand

Chand Kare Technical Ceramics

2 Coppage Drive

Worcester, MA 01603

178. Robert E. Chaney

EG\&G Idaho, Inc.

Idaho National Engineering Laboratory

P.0. Box 1625

Idaho Falls, ID 83415-3525

179. Frank C. Chang

U.S. Army Materials Technology Laboratory

AMTL-EMM

405 Arsenal Street

Watertown, MA 02172

180. Robert M. Chapman

Allied-Signal Aerospace Company

1530 Wilson Boulevard, 10th Floor

Arlington, VA 22209
181. William Chapman

Williams International

Corporation

2280 West Maple Road

Walled Lake, MI 48390-0200

182. Charlie Chen

LECO Corporation

P.0. Box 211688

Augusta, GA 30917

183. Albert A. Chesnes

U.S. Department of Energy

Transportation Technologies

CE-30, Forrestal Building, 6B-094

Washington, DC 20585

184. Kaiyin Chia

Carborundum Company

P.0. Box 832

Niagara Falls, NY 14302

185. Frank Childs

EG\&G Idaho, Inc.

Idaho National Engineering Laboratory

P.0. Box 1625

Idaho Falls, ID 83415-3527

186. William J. Chmura

Torrington Company

59 Field Street

Torrington, CT 06790-4942

187. Tsu-Wei Chou

University of Delaware

Center for Composite

Materials

201 Spencer Laboratory

Newark, DE 19716

188. R. J. Christopher

Ricardo Consulting Engineers

Bridge Works

Shoreham-By-Sea West Sussex BN43 5FG

ENGLAND AIR MAIL

189. Joel P. Clark

Massachusetts Institute of Technology

Room 8-409

Cambridge, MA 02139 
190. Giorgio Clarotti

Commission of the European

Communities

DGXII-C3, M075, 1-53;

200 Rue de la Loi

B-1049 Brussels

BELGIUM AIR MAIL

191. W. J. Clegg

ICI Advanced Materials

P.0. Box 11

The Heath, Runcorn Cheshire

WA7 4QE

ENGLAND

AIR MAIL

192. Joseph Cleveland

GTE Products Corporation

Hawes Street

Towanda, PA 18848-0504

193. Gloria M. Collins

ASTM

1916 Race Street

Philadelphia, PA 19103

194. William C. Connors

Sundstrand Aviation Operations

Materials Science and

Engineering Department

4747 Harrison Avenue

P.0. Box 7002

Rockford, IL 61125-7002

195. John A. Coppola

Carborundum Company

P.0. Box 156

Niagara Falls, NY 14302

196. Normand D. Corbin

Norton Company

Advanced Ceramics

Goddard Road

Northboro, MA 01532-1545

197. Douglas Corey

Allied-Signal Aerospace Company

2525 West 190th Street

MS: T52

Torrance, CA 90504-6099
198. Keith P. Costello

Chand/Kare Technical Ceramics

2 Coppage Drive

Worcester, MA 01603-1252

199. Ed L. Courtright

Pacific Northwest Laboratory

MS : K3-59

Richland, WA 99352

200. Anna Cox

Mitchell Market Reports

P.0. Box 23

Monmouth Gwent NP5 AYG

UNITED KINGDOM AIR MAIL

201. Thomas Coyle

Unocal Corporation

Unocal Science \& Technology

Division

376 South Valencia Avenue

Brea, CA 92621

202. Art Cozens

Instron Corporation

3414 Snowden Avenue

Long Beach, CA y0808

203. Robert C. Craft

American Ceramic Society, Inc.

757 Brooksedge Plaza Drive

Westerville, $\mathrm{OH} 43081$

204. Mark Crawford

New Technology Week

4604 Monterey Drive

Annandale, VA 22003

205. Richard A. Cree

Markets \& Products, Inc.

P.0. Box 14328

Columbus, $\mathrm{OH}$ 43214-0328

206. Les Crittenden

Vesuvius McDanel

Box 560

Beaver Falls, PA 15010 
207. William J. Croft

U.S. Army Materials Technology Laboratory

405 Arsenal Street

Watertown, MA 02172

208. M. J. Cronin

Mechanical Technology, Inc.

968 Albany-Shaker Road

Latham, NY 12110

209. Gary M. Crosbie

Ford Motor Company

1430 Culver Avenue

S-2079, SRL Building

Dearborn, MI 48121-4036

210. Floyd W. Crouse, Jr.

U.S. Department of Energy

Morgantown Energy Technology Center

Collins Ferry Road

P.0. Box 880

Morgantown, WV 26505

211. John Cuccio

Allied-Signal Aerospace Company

Garrett Auxiliary Power Division

P.0. Box 5227, MS: $1302-2 Q$

Phoenix, AZ 85010

212. Raymond Cutler

Ceramatec, Inc.

2425 South 900 West

Salt l.ake City, UT 84119

213. Charles D'Angelo

GTE Laboratories, Inc.

40 Sylvan Road

Wal tham, MA 02154

214. Stephen C. Danforth

Rutgers University

Ceramic Engineering Department P.0. Box 909

Piscataway, NJ 08855-0909
215. Sankar Das Gupta

Electrofuel Manufacturing Co., Ltd.

9 Hanna Avenue

Toronto Ontario MGK-1W8

CANADA AIR MAIL

216. Charles Davis

Sverdrup Technology, Inc., MSFC

620 Discovery Drive

Huntsville, AL 35806

217. Frank Davis

Allied Signal Aerospace Co.

7550 Lucerne Or., \# 203

Middleburg Heights, OH 44130

218. Robert F. Davis

North Carolina State University

Materials Engineering Department

229 Riddick Laboratory

P.0. Box 7907

Raleigh, NC 27695

219. Thomas DeAngel is

Carborundum Company

Niagara Falls R\&D Center

P.0. Box 832

Niagara Falls, NY 14302

220. George DeBell

Ford Motor Company

Material Systems Reliability

Department

20000 Rotunda Drive

P.0. Box 2053, Room S-2023

Dearborn, MI 48121-2053

221. Michael Deluca

AMP-AKZO

West Lane

Aquebogue, NY 11931

222. Gerald L. DePoorter Colorado School of Mines

Metallurgical and Materials

Engineering Department

Golden, CO 80401 
223. J. F. DeRidder

Omni Electro Motive, Inc.,

12 Seely Hill Road

Newfield, NY 14867

224. Nick C. Dellow

Materials Technology

Publications

40 Sotheron Road

Watford Herts WDI 2QA

UNITED KINGDOM AIR MAIL

225. L. R. Dharani

University of Missouri-Rolla

224 M.E.

Rolla, MO 65401

226. Douglas A. Dickerson

Union Carbide Specialty

Powders

1555 Main Street

Indianapolis, IN 46224

227. John Dodsworth

Vesuvius Research \& Development

Technical Ceramics Group

Box 560

Beaver Falls, PA 15010

228. B. Dogan

Institut fur Werkstofforschung GKSS-Forschungszentrum

Geesthacht GmbH

Max-PIanck-Strasse

D-2054 Geesthacht

GERMANY AIR MAIL

229. Jean-Marie Drapier

FN Moteurs S.A.

Material and Processing

B-4041 Milmort (Herstal)

BELGIUM AIR MAIL

230. Kenneth C. Dreitlein

United Technologies

Research Center

Silver Lane

East Hartford, CT 06108
231. Robin A.L. Drew

McGill University

Department of Mining and

Metallurgical Engineering

3450 University Street

Montreal Quebec H3A 2A7

CANADA AIR MAIL

232. Winston H. Duckworth

$\mathrm{BCL}$

Columbus Division

505 King Avenue

Columbus, $\mathrm{OH}$ 43201-2693

233. Edmund M. Dunn

Texel Company

6 Third Street

Lexington, MA 02173

234. Bill Durako

Sundstrand Aviation Operations

Department 789-6

4747 Harrison Avenue

P.0. Box 7002

Rockford, IL 61125-7002

235. Ernest J. Duwell

212 Elm Street

Hudson, WI 54016

236. Chuck J. Dziedzic

Coors Ceramics Company

Structural Products Group

17750 West 32nd Avenue

Golden, CO 80401

237. Robert J. Eagan

Sandia National Laboratories

Engineered Materials \& Processes Center

Org 1700

P.0. Box 5800

Albuquerque, NM 87185-5800

238. Jeffrey Eagleson

Lanxide Corporation

1001 Connecticut Avenue, N.W.

Washington, DC 20036 
239. Harry E. Eaton

United Technologies Corporation

Research Center

Silver Lane

East Hartford, CT 06108

240. Harvili C. Eaton

Louisiana State

University

Office of Research

and Economic Development

240 Thomas Boyd Hall

Baton Rouge, LA 70803

241. Christopher A. Ebel

Carborundum Company

Technology Division

P. 0. Box 337

Niagara Falls, NY 14302

242. J. J. Eberhardt

U.S. Department of Energy

Office of Transportation Materials

CE-34, Forrestal Building

Washington, DC 20585

243. Jim Edler

Eaton Corporation

26201 Northwestern

Highway

P.0. Box 766

Southfield, MI 48037

244. William A. Ellingson

Argonne National Laboratory

Materials Science \& Technology Division

9700 South Cass Avenue

Argonne, IL. 60439

245. William S. Ellis

Machined Ceramics

629 N. Graham St.

N. Industrial Park

Bowling Green, KY 42101

246. Glen B. Engle

Nuclear \& Rerospace Materials

Corporation

16716 Martincoit Road

Poway, CA 92064
247. Jeff Epstein

Ceramic Technologies, Inc.

2107 Jamara Lane

Houston, TX 77077

248. Kenneth A. Epstein

Dow Chemical U.S.A.

Ceramics and Advanced Materials

800 Building

Midland, MI 48667

249. Art Erdemir

Argonne National Laboratory

Materials and Components

Technology Division

9700 South Cass Avenue

Argonne, IL 60439

250. E. M. Erwin

Lubrizol Corporation

1819 East 225th Street

Euclid, $\mathrm{OH} 44117$

25i. Kenji Esaki

Toyota Technical Center U.S.A., Inc.

2000 Town Center, Suite 500

Southfield, MI 48075

252. Jose L. Escalante

Anglo-Mex-Tech. Inc.

3923 N.W. 24th Street

Miami, FL 33142

253. John N. Eustis

U.S. Department of Energy

Industrial Energy Efficiency

Division

CE-221, Forrestal Building

Washington, DC 20585

254. Robert C. Evans

NASA Lewis Research Center

Terrestrial Propulsion Office

21000 Brookpark Road, MS:86-6

Cleveland, $\mathrm{OH} 44135$

255. W. L. Everitt

Kyocera International, Inc.

8611 Balboa Avenue

San Diego, CA 92123 
256. Gordon Q. Evison

332 South Michigan Avenue

Suite 1730

Chicago, II. 60604

257. John W. Fairbanks

U.S. Department of Energy

Advanced Propulsion Division

CE-322, Forrestal Building

Washington, DC 20585

258. Tim Fawcett

Dow Chemical Company

Central Research, Advanced

Ceramics Laboratory

1776 Building

Midland, MI 48674

259. Robert W. Fawley

Sundstrand Power Systems

Division of Sundstrand

Corporation

4400 Ruffin Road

P.0. Box 85757

San Diego, CA 92186-5757

260. John J. Fedorchak

GTE Products Corporation

Hawes Street

Towanda, PA 18848-0504

261. Jeff T. Fenton

Vista Chemical Company

900 Threadneedle

Houston, TX 77079

262. Larry Ferrell

Babcock \& Wilcox

01d Forest Road

Lynchburg, VA 24505

263. Raymond R. Fessier

BIRL

Industrial Research Lab

1801 Maple Avenue

Evanston, IL 60201

264. Michelle Finch

E. I. Dupont de Nemours \&

Company, Inc.

Experimental Station

Information Center E302/301

Wilmington, DE 19898
265. Arthur D. Fine

United Technologies Corporation

Pratt \& Whitney Aircraft

$400 \mathrm{Ma}$ in Street

MS: $163-10$

East Hartford, CT 06108

266. Ross F. Firestone

Ross Firesione Company

188 Mary Street

Winnetka, IL 60093-1520

267. Sharon L. Fletcher

Arthur D. Little, Inc.

15 Acorn Park

Cambridge, MA 02140-2390

268. Thomas F. Foltz

Textron Specialty Materials

2 Industrial Avenue

Lowe 11, MA 01851

269. Renee G. Ford

Materials and Processing Report

P.0. Box 72

Harrison, NY 10528

270. John Formica

Supermaterials

2020 Lakeside Avenue

Cleveland, $\mathrm{OH} 44114$

271. Jennifer M. Fox

Dyson Refractories Limited

R\&D Laboratory

Owler Bar

Sheffield 517 3BJ

UNITED KINGDOM AIR MAIL

272. Edwin Frame

Southwest Research Institute

Division 2

P.0. Drawer 28510

San Antonio, TX 78284

273. Armanet Francois

French Scientific Mission

4101 Reservoir Road, N.W.

Washington DC 20007-2176

274. R. G. Frank

Technology Assessment Group

10793 Bentley Pass Lane

Lovel and, $\mathrm{OH} 45140$ 
275. David J. Franus Forecast International

22 Commerce Road

Newtown, CT 06470

276. Marc R. Freedman

NASA Lewis Research Center

21000 Brookpark Road

MS: 49-3

Cleveland, $\mathrm{OH} 44135$

277. Douglas Freitag

LTV Missiles Division

P.0. Box 650003

MS:WT-21

Dallas, TX 75265

278. Brian R.T. Frost

Argonne National Laboratory

9700 South Cass Avenue

Building 900

Argonne, IL 60439

279. Lawrence R. Frost

Instron Corporation

100 Royall Street

Canton, MA 02021

280. George A. Fryburg

Norton/TRW Ceramics

7A-4 Raymond Avenue

Salem, NH 03079

281. Xiren $\mathrm{Fu}$

Shanghai Institute of Ceramics

Chinese Academy of Sciences

1295 Ding-xi Road

Shanghai 200050

CHINA AIR MAIL

282. John Gahimer

P. O. Box 1302

Dubl in, OH 43017

283. J. P. Gallagher

University of Dayton Research Institute

300 College Park, JPC-250

Dayton, OH 45469-0120
284. Tom Garritano

University of Tennessee

Science Alliance

101 South College

Knoxville, TN 37996-1328

285. Joy A. Garwood

Norton Company

Advanced Ceramics

Goddard Road

Northboro, MA 01532-1545

286. H. Maury Gatewood

Reynolds Metals Company Corporate R\&D

Fourth and Canal Streets

P.0. Box 27003

Richmond, VA 23261

287. L. J. Gauckler

ETH-Zurich

Sonneggstrasse 5

CH-8092 Zurich 8092

SWITZERLAND

AIR MAIL

288. Peter A. Gaydos

Battelle Columbus Laboratories

$505 \mathrm{King}$ Avenue

Columbus, $\mathrm{OH} 43201$

289. George E. Gazza

U.S. Army Materials

Technology Laboratory

Ceramics Research Division

405 Arsenal Street

Watertown, MA 02172-0001

290. D. Gerster

CEA.DC.OM

33 Rue De La Federation

Paris 75015

FRANCE AIR MAIL

291. John Ghinazzi

Coors Technical Ceramics Company

1100 Commerce Park Drive

Oak Ridge, TN 37830 
343. Richard Holt

National Research Council of Canada

Structures and Materials Laboratory

Ottawa Ontario KIA OR6

CANADA AIR MAIL

344. Joseph Homeny

University of 111 inois

Department of Materials Science and Engineering

105 South Goodwin Avenue

Ceramics Building

Urbana, IL 61801

345. A. T. Hopper

Battelle Columbus Laboratories

Metals and Ceramics Department

505 King Avenue

Columbus, $\mathrm{OH}$ 43201-2693

346. Michael Horgan

Materials Engineering Magazine

1100 Superior Avenue

Cleveland, $\mathrm{OH} 44114$

347. Woodie Howe

Coors Technical Ceramics

Company

1100 Conmerce Park Drive

Oak Ridge, TN 37830

348. Stephen M. Hsu

National Institute of

Standards and Technology

Gaithersburg, MD 20899

349. Hann S. Huang

Argonne National Laboratory

9700 South Cass Avenue

Argonne, IL 60439-4815

350. Gene Huber

Precision Ferrites \& Ceramics

5576 Corporate Drive

Cypress, CA 90630

351. M. L. Huckabee

GTE Laboratories, Inc.

40 Sylvan Road

Waltham, MA 02254
352. Harold A. Huckins

Princeton Advanced

Technology, Inc.

56 Finley Road

Princeton, NJ 08540

353. Fred R. Huettic

Advanced Magnetics, Inc.

45 Corey Lane

Mendham, NW. 07945

354. Bill Huffman

Zircar

110 North Main Street

Florida, NY 10921

355. Brian K. Humphrey

Lubrizol Petroleum

Chemicals Co.

3000 Town Center, Suite 1340

Southfield, MI 48075-1201

356. Robert M. Humrick

Dylon Ceramic Technologies

3100 Edgehill Road

Cleveland Heights, $\mathrm{OH} \$ 4118$

357. Lorretta Inglehart

National Science Foundation

Division of Materials Research

1800 "G" Street, N.W.,

Room 408

Washington, DC 20550

358. Michael S. Inoue

Kyocera International, Inc.

KII Library

8611 Balboa Avenue

San Diego, CA 92123-1580

359. Osama Jadaan

University of WisconsinPlatteville

General Engineering Division

1 University Plaza

Platteville, WI 53818

360. Curtis A. Johnson

General Electric Company Corporate R\&D

Room MB-187

P.0. Box 8

Schenectady, NY 12301 
361. Sylvia Johnson

SRI International

333 Ravenswood Avenue

Menlo Park, CA 94025

362. Thomas A. Johnson Lanxide Corporation

1300 Marrows Road

P.0. Box 6077

Newark, DE 19714-6077

363. W. S. Johnson

Indiana University

One City Centre, Suite 200

Bloomington, IN $\mathbf{4 7 4 0 5}$

364. Jill E. Jonkouski

U.S. Department of Energy

9800 South Cass Avenue

Argonne, IL 60439-4899

365. L. A. Joo

Great Lakes Research Corporation

P.0. Box 1031

Elizabethton, TN 37643

366. A. D. Joseph

SPX Corporation

700 Terrace Point.

Muskegon, MI 49443

367. Adam Jostsons

Australian Nuclear Science \& Technology Organization

Lucas Heights Research Laboratories

New Ill awarra Road

Lucas Heights New South Wales

AUSTRALIA AIR MAIL

368. Matthew K. Juneau

Ethyl Corporation

451 Florida Street

Baton Rouge, LA 70801

369. Hartmut Kainer

Didier-Werke AG

Anlagentechnik Wiesbaden

Abraham-Lincoln-Str. 16

D-62 Wiesbaden

GERMANY

AIR MAIL
370. Tom Kalamasz

Norton/TRW Ceramics

7A-4 Raymond Avenue

Salem, NH 03079

371. Lyle R. Kallenbach

Phillips Petroleum Company

R\&D

MaiT Drop:123AL

Bartlesville, OK 74004

372. Nick Kamiya

Kyocera Industrial Ceramics

Corporation

2700 River Road

Des Plaines, IL 60018

373. Roy Kamo

Adiabatics, Inc.

3385 Commerce Park Drive

Columbus, IN 47201

374. S. Kang

GTE Laboratories, Inc.

40 Sylvan Road

Wal tham, MA 02254

375. Chih-Chun Kao

Industrial Technology Research Institute

Materials Research

Laboratories

195 Chung-Hsing Road, Sec. 4

Chutung Hsinchu 31015 R.0.C.

TAIWAN AIR MAIL

376. Keith R. Karasek

Allied-Signa1, Inc.

Engineered Materials Research Center

50 East Algonquin Road

P.0. Box 5016

Des PTaines, IL 60017-5016

377. Robert E. Kassel

Ceradyne, Inc.

3169 Redhill Avenue

Costa Mesa, CA 92626

378. Allan Katz

Wright Laboratory

Metais and Ceramics Division WL/MLLM

Wright-Patterson AFB, OH 45433 
379. R. Nathan Katz

Worcester Polytechnic

Institute

Dept. of Mechanical

Engineering

100 Institute Road

Worcester, MA 01609

380. Ted Kawaguchi

Tokai Carbon America, Inc.

375 Park Avenue, Suite 3802

New York, NY 10152

381. Noritsugu Kawashima

TOSHIBA Corporation

Mechanical Engineering Laboratory

4-1 Ukishima-Cho

Kawasaki-Ku Kawasaki 210

JAPAN AIR MAIL

382. Lisa Kempfer

Penton Publishing

Materials Engineering

1100 Superior Avenue

Cleveland, $\mathrm{OH} \mathrm{44114-2543}$

383. Frederick L. Kennard, III

General Motors Corporation

AC Rochester

Department 32-24, EB

1300 North Dort Highway

Flint, MI 48556

384. David 0. Kennedy

Lester B. Knight Cast

Metals Inc.

549 West Randolph Street

Chicago, IL 60661

385. George Keros

Photon Physics

3175 Penobscot Building

Detroit, MI 48226

386. Pramod K. Khandelwal

General Motors Corporation

Allison Gas Turbine Division

P.0. Box 420, MS:W05

Indianapolis, IN 46206
387. Jim R. Kidwell

Allied-Signal Aerospace Company

Garrett Auxiliary Power Division

P.0. Box 5227

Phoenix, AZ 85010

388. Han J. Kim

GTE Laboratories, Inc.

40 Sylvan Road

Haltham, MA 02254

389. Shin Kim

Korea Institute of Machinery \& Meicals

66 Sangnam-dong, Changwon

Kyungnam 641-010

KOREA AIR MAIL

390. W. C. King

Hack Truck, 2-41

1999 Pennsylvania Avenue

Hagerstown, MD 21740

391. Carol Kirkpatrick

MSE, Inc.

CDIF Technical Library

P.0. Box 3767

Butte, MT 59702

392. Tony Kirn

Caterpillar, Inc.

Defense Products Department, JB7

Peoria, IL 61629

393. James D. Kiser

NASA Lewis Research Center

21000 Brookpark Road, MS:49-3

Clevel and, $\mathrm{OH} 44135$

394. Max Klein

Gas Research Institute

Thermodynamics

8600 West Bryn Mawr Avenue

Chicago, IL 60631

395. Richard N. Kleiner

Coors Ceramics Company

4545 McIntyre Street

Golden, CO 80403 
396. Stanley J. Klima

NASA Lewis Research Center

21000 Brookpark Road

MS: $6-1$

Cleveland, $\mathrm{OH} 44135$

397. Chris E. Knapp

Norton Advanced Ceramics of Canada Ltd.

8001 Daly Street

Niagara Falls, Ontario L2G 6S2 CANADA AIR MAIL

398. Albert S. Kobayashi

University of Washington

Mechanical Engineering Department

MS:FU10

Seattle, WA 98195

399. Shigeki Kobayashi

Toyota Central Research Labs, Inc.

Nagakute Aichi 480-11

JAPAN AIR MAIL

400. Richard A. Kole

Z-Tech Corporation

8 Dow Road

Bow, NH 03304

401. E. Kostiner

University of Connecticut

Chemistry Department, U-60

Storrs, CT 06269-3060

402. Kenneth A. Kovaly

Technical Insights, Inc.

P.0. Box 1304

Fort Lee, NJ 07024-9967

403. Ralph G. Kraft

Spraying Systems Company

North Avenue at Schmale Road

Wheaton, IL 60189-7900

404. Saunders B. Kramer

U.S. Department of Energy

Advanced Propulsion Division

CE-322, Forrestal Building

Washington, DC 20585
405. Arthur Kranish

Trends Publishing, Inc.

1079 National Press Building

Washington, DC 20045

406. A. S. Krieger

Radiation Science, Inc.

P.0. Box 293

Belmont, MA 02178

407. Pieter Krijgsman

Ceramic Design International Holding B.V.

P.0. Box 68

Hattem $8050-A B$

THE NETHERLANDS

AIR MAIL

408. Waltraud M. Kriven

University of Illinois

Materials Science and

Engineering Department

105 South Goodwin Avenue

Urbana, IL 61801

409. Edward J. Kubel, Jr.

ASM International Advanced

Materials \& Processes

Materials Park, OH 44073

410. Dave Kupperman

Argonne National Laboratory

9700 South Cass Avenue

Argonne, IL 60439

411. Oh-Hun Kwon

Norton Company

Advanced Ceramics

Goddard Road

Northboro, MA 01532-1545

412. W. J. Lackey

Georgia Institute of Technology

Materials Science and

Technology

At7anta, GA 30332

413. Jai Lala

Tenmat Ltd.

40 Somers Road

Rugby Warwickshire CV22 7DH

ENGLAND AIR MAIL 
414. Hari S. Lamba

General Motors Corporation

Electro-Motive Division

9301 West 55th Street

LaGrange, IL 60525

415. Richard L. Landingham

Lawrence Livermore National Laboratory

Ceramics, Corrosion, and

Thermochemistry

P. 0. BoX 808, L-369

Livermore, CA 94550

416. Charles J. Landry

Chand Kare Technical Ceramics

712 Flat Hill Road

Lumenburg, MA 01462

417. Manfred W. Langer

Volkswagen AG

Material Technology

3180 Wol fsburg 1

GERMANY AIR MAIL

418. James Lankford

Southwest Research Institute

Department of Materials

Sciences

6220 Culebra Road

San Antonio, TX 78228-0510

419. Stanley B. Lasday

Business News Publishing Co.

Manor Oak One

1910 Cochran Road, Suite 630

Pittsburgh, PA 15220

420. Mark S. Laser

Solar Turbines, Inc.

2211 Erie Street

San Diego, CA 92110

421. S. K. Lau

Carborundum Company

Technology Division

P.0. Box 832, B- 100

Niagara Falls, NY 14302

422. Edward A. Lauder

Advanced Composite Materials Corporation

1525 South Buncombe Road

Greer, SC 29651-9208
423. J. Lawrence Lauderdale

Babcock \& Wilcox

Contract Research Division

1850 "K" Street, Suite 950

Washington, DC 20006

424. Harry A. Lawler

Carborundum Company

Technology Division

P.0. Box 832

Niagara Falls, NY 14302

425. Jean F. LeCostaouec

Textron Speciality Materials

2 Industrial Avenue

Lowe11, MA 01851

426. Benson P. Lee

Interscience, Inc.

9718 Lake Shore Boulevard

Cleveland, $\mathrm{OH} 44108$

427. Burtrand I. Lee

Clemson University

Department of Ceramic Engineering

01 in $\mathrm{Hall}$

Clemson, SC 29634-0907

428. June-Gunn Lee

KIST

Structural Ceramic Lab

P.0. Box 131, Cheong-Ryang

Seout 130.650

KOREA AIR MAIL

429. Ran-Rong Lee

Ceramics Process Systems

Corporation

155 Fortune Boulevard

Milford, MA 01757

430. Stan Levine

NASA Lewis Research Center 21000 Brookpark Road

MS : 49-3

Clevel and, $\mathrm{OH} 44135$

431. Alan V. Levy

Lawrence Berkeley Laboratory

One Cyclotron Road, MS:62-203

Berkeley, CA 94720 
432. Ai-Kang $L i$

Materials Research Laboratories, ITRI

195-5 Chung-Hsing Road, Sec. 4 Chutung Hsinchu 31015 R.O.C.

TAIWAN AIR MAIL

433. Winston W. Liang

Hong Kong Industrial

Technology Centre Co. Ltd.

78 Tat Chee Avenue

4/F, HKPC Building

Howloon

HONG KONG AIR MAIL

434. Robert Licht

Norton Company

Advanced Ceramics

Goddard Road

Northboro, MA 01532-1545

435. E. Lilley

Norton Company

Advanced Ceramics

Goddard Road

Northboro, MA 01532-1545

436. Laura J. Lindberg

Allied-Signal Aerospace Company

Garrett Fluid Systems Division

1300 West Warner

MS: 93-901-1207-4TT

P.0. Box 22200

Tempe, AZ 85284-2200

437. Leonard C. Lindgren

General Mutors Corporation

Allison Gas Turbine Division

P.0. Box 420, Speed Code:T-20A

Indianapol is, IN 46206-0420

438. Hans A. Lindner

Cremer Forschungsinstitut GmbH\&CO.KG

Oeslauer Strasse 35

D-8633 Rodental 8866

GERMANY AIR MAIL
439. Ronald E. Loehman

Sandia National Laboratories

Chemistry \& Ceramics

Department 1840

P.0. Box 5800

Aibuquerque, NM 87185

440. Jeffrey C. Logas

Winona State University

Composite Materials Engineering

115 Pasteur Hall

Winona, MN 55987

441. Bill Long

Babcock \& Wilcox

P.0. Box 11165

Lynchburg, VA 24506

442. William D. Long

Wacker Chemicals (USA), Inc.

ESK Engineered Ceramics

50 Locust Avenue

New Canaan, CT 06840

443. L. A. Lott

EG\&G Idaho, Inc.

Idaho National Engineering Laboratory

P.0. Box 1625

Idaho Falls, ID 83415-2209

444. Raouf 0. Loutfy

MER Corporation

7960 South Kolb Road

Tucson, AZ 85706

445. Gordon R. Love

Aluminum Company of America

Alcoa Technical Center

Alcoa Center, PA 15069

446. Lydia Luckevich

Ortech International

2395 Speakman Drive

Mississauga Oniario L5K 1 B3

CANADA AIR MAIL 
447. James W. MacBeth

Carborundum Company

Structural Ceramics Division

P.0. Box 1054

Niagara Falls, NY 14302

448. H. MacLaren

General Electric Company

Thomson Laboratory, Materials

Engineering 36807

1000 Western Avenue

Lynn, MA 01910

449. George Maczura

Aluminum Company of America

Industrial Chemicals Division

670 One Allegheny Square

Pittsburgh, PA 15212

450. David Maginnis

Tinker AFB

OC-ALC/LIIRE

Tinker AFB OK 73145-5989

451. Frank Maginnis

Aspen Research, Inc.

220 Industrial Boulevard

Moore, OK 73160

452. Tai-il Mah

Universal Energy Systems, Inc.

Ceramics and Composites

Research

4401 Dayton-Xenia Road

Dayton, $\mathrm{OH} 45432$

453. Kenneth M. Maillar

Barbour Stockwell Company

83 Linskey Way

Cambridge, MA 02142

454. Lorenzo Majno

Instron Corporation

100 Royall Street

Canton, MA 02021

455. S. G. Malghan

National Institute of Standards and Technology

I-270 \& Clopper Road

Gaithersburg, MD 20899
456. Lars Malmrup

United Turbine $A B$

Box 13027

Malmo S-200 44

SWEDEN AIR MAIL

457. John Mangels

Ceradyne, Inc.

3169 Redhill Avenue

Costa Mesa,-CA 92626

458. Russell V. Mann

Matec Applied Sciences, Inc.

75 South Street

Hopkinton, MA 01748

459. William R. Manning

Champion Aviation Products

Division

Old Norris Road

P.0. Box 686

Liberty, SC 29657

460. Ken Marnoch

Amercom, Inc.

8928 Ful lbright Avenue

Chatsworth, CA 91311

461. Robert A. Marra

Aluminum Company of America

Alcoa Technical Center

Advanced Ceramics Center - E

Alcoa Center, PA 15069

462. Chauncey L. Martin

3M Company

3M Center, Building 60-1N-01

St. Paul, MN 55144

463. Steven C. Martin

Advanced Refractory

Technologies, Inc.

699 Hertel Avenue

Buffalo, NY 14207

464. Kelly J. Mather

Williams International

Corporation

2280 West Maple Road

P.0. Box 200

Walled Lake, MI 48088 
465. James $P$. Mathers

3M Company

$3 M$ Center

Building 201-3N-06

St. Paui, MN 55144

466. Marshall Mayer

Instron Corporation

3815 Presidential Parkway, Suite 100

Atlanta, GA 30340

467. Ron Mayville

Arthur D. Little, Inc.

15-163 Acorn Park

Cambridge, MA 02140

468. F. N. Mazadarany

General Electric Company

Research Laboratory

Building K-1, Room MB-159

P.0. Box 8

Schenectady, NY 12301

469. James W. McCauiey

Alfred University

NYS College of Ceramics

Binns-Merrill Hall

Alfred, NY 14802

470. Carolyn McCormick

Allied-Signal Aerospace Company

Garrett Auxiliary Power

Division

Bidg. 1303-206

P.0. Box 5227, MS:9317-2

Phoenix, AZ 85010

471. Louis R. McCreight

2763 San Ramon Drive

Rancho Palos Verdes, CA 90274

472. Col in F. McDonald

McDonald Thermal Engineering

1730 Castellana Road

La Jolla, CA 92037

473. B. J. McEntire

Norton Company, TRW Ceramics Goddard Road

Northboro, MA 01532-1545
474. Chuck McFadden

Coors Ceramics Company

600 9th Street

Golden, CO 80401

475. Henry McFadden

Magnetic Bearings, Inc.

Engineering Library

609 Rock Road

Radford, VA. 24141

476. Thomas D. McGee

Iowa State University

Materials Science and

Engineering Department

110 Engineering Annex

Ames, IA 50011

477. Carol McGill

Corning Inc.

Sullivan Park, FR-02-08

Corning, NY 14831

478, T. C. McLaren

Carneron Forged Products Company

P.0. Box 1212

Houston, TX 77251-1212

479. James McLaughl in

Sundstrand Power Systems

4400 Ruffin Road

P.0. Box 85757

San Diego, CA 92186-5757

480. Arthur F. McLean

6225 North Camino Almonte

Tucson, AZ 85718

481. Matt McMonigle

U.S. Department of Energy

Improved Energy Productivity Division

Forrestal Building, CE-231

Washington, DC 20585

482. Dennis McMurtry

EG\&G Idaho, Inc.

Idaho National Engineering Laboratory

P.0. Box 1625

Idaho Falls, ID 83415 
483. D. B. Meadowcroft

National Power Technology and Environmental Centre

Kelvin Avenue

Leatherhead Surrey KT22 7SE

ENGLAND AIR MAIL

484. Jo Meglen

11004 Birdfoot Court

Reston, VA 22091

485. Pankaj K. Mehrotra

Kennametal, Inc.

P.0. Box 639

Greensburg, PA 15601

486. Joseph J. Meind 1

Reynolds International, Inc.

6603 West Broad Street

P.0. Box 27002

Richmond, VA 23261-7003

487. Michael D. Meiser

Allied-Signal Aerospace Company

Garrett Ceramic Components Division

19800 South Van Ness Avenue

Torrance, CA 90509

488. George Messenger

National Research Council of Canada

Engine Laboratory

Building M-7

Ottawa Ontario K1A OR6

CANADA AIR MAIL

489. D. Messier

U.S. Army Materials Technology Laboratory

SLCMT-EMC

405 Arsenal Street

Watertown, MA 02172-0001

490. Gary L. Messing

Pennsylvania State University

Ceramic Science and Engineering Department

119 Steidle Building

University Park, PA 16802
491. Arthur G. Metcalfe

Arthur G. Metcalfe and Associates, Inc.

2108 East 24th Street National City, CA 91950

492. R. Metselaar

Eindhoven University

Centre for Technical Ceramics

P.0. Box 513

Eindhoven $5600 \mathrm{MB}$

THE NETHERLANDS

AIR MAIL

493. Nancy S. Meyers

U.S. Department of Energy

Transportation Technologies

CE-30, Forrestal Building 6B-094

Washington, DC 20585

494. David J. Michael

Harbison-Walker Refractories

Company

P.0. Box 98037

Pittsburgh, PA 15227

495. Ken Michaels

Chrysler Motors Corporation

Ceramics Development

Metallurgical Processes

P.0. Box 1118, CIMS:418-17-09

Detroit, MI 48288

496. Bernd Michel

Institute of Mechanics

Fracture and Micromechanics

Department

P.0. Box 40?

D-9010 Chemı itz

GERMANY AIR MAIL

497. David E. Miles

Commission of the European Communities

rue de la Loi, 200

B-1049 Brusseis

BELGIUM AIR MAIL

498. John V. Milewski

Superkinetics, Inc.

P.0. Box 8029

Santa Fe, NM 87504 
499. Carl E. Miller

AC Rochester

1300 North Dort Highway, MS : 32-31

Engineering Building B

Flint, MI 48556

500. Mike Miller

McGraw-Hill Aviation Week

Perfolmance Materials

1156 15th Street, N.W. Washington, DC 20005

501. Charles W. Miller, Jr.

Centorr Furnaces/Vacuum Industries

542 Amherst Street

Nashua, NH 03063

502. R. Mininni

Enichem America

2000 Cornwall Road

Monmouth Junction, NJ 08852

503. Michele V. Mitchell

Allied-Signal Aerospace

Company

Garrett Ceramic Components

Division

19800 South Van Ness Avenue

Torrance, CA 90501-1149

504. Howard Mizuhara

GTE - WESGO

477 Harbor Boulevard

Belmont, CA 94002

505. Helen Moeller

Babcock \& Wilcox

P.D. Box 11165

Lynchburg, VA 24506-1165

506. Francois R. Mollard

Metalworking Technology, Inc.

1450 Scalp Avenue

Johnstown, PA 15904

507. Phil Mooney

Panametrics

NDE Division

221 Crescent Street

Waltham, MA 02254
508. Thomas Morel

Ricardo North America

645 Blackhawk Drive

Westmont, IL 60559

509. Geoffrey P. Morris

3M Company

3M Traffic Control Materials Division

Bldg. 209-BW-10, 3M Center

St. Paut, MN 55144-1000

510. Jay A. Morrison

Rolls-Royce, Inc.

Engineering and Information Center, Overlook 1

2849 Paces Ferry Road, Suite 450

Atlanta, GA 30339-3769

511. Joel P. Moskowitz

Ceradyne, Inc.

3169 Redhill Avenue

Costa Mesa, CA 92626

512. Brij Moudgil

University of Florida

Material Science and Engineering

Gainesville, FL 32611

513. Christoph J. Mueller

Sprechsaal Publishing Group

P.0. Box 2962, Mauer 2 D-8630 Coburg

GERMANY AIR MAIL

514. Thomas W. Mullan

Vapor Technologies Inc.

345 Route 17 South

Upper Saddle River, NJ 07458

515. M. K. Murthy

MKM Consultants International

10 Avoca Avenue, Unit 1906

Toronto Ontario M4T $2 B 7$

CANADA AIR MAIL

516. Solomon Musikant

TransCon Technologies, Inc.

Materials Science \& Engineering

1508 Waynesboro Road

Paoli, PA 19301 
517. David L. Mustoe

Custom Technical Ceramics 8041 West I-70 Service Road, Unit 6

Arvada, CO 80002

518. Curtis V. Nakaishi

U.S. Department of Energy Morgantown Energy Technology Center

Collins Ferry Road

P.0. Box 880

Morgantown, WV 26507-0880

519. Yoshio Nakamura

Faicera Research Institute 2-5-8 Hiyakunin-cho Shinjuku-Ko Tokyo

JAPAN AIR MAIL

520. K. S. Narasimhan

Hoeganaes Corporation

River Road

Riverton, NJ 08077

521. Samuel Natansohn

GTE Laboratories, Inc.

40 Sylvan Road

Waltham, MA 02254

522. Robert Naum

Applied Resources, Inc.

P.0. Box 241

Pittsford, NY 14534

523. Malcolm Naylor

Cummins Engine Company, Inc.

P.0. Box 3005, Mail Code 50183

Columbus, IN 47202-3005

524. Jeffrey Neil

GTE Laboratories, Inc.

40 Sylvan Road

Waltham, MA 02254

525. Fred A. Nichols

Argonne National Laboratory

9700 South Cass Avenue

MCT - Building 212

Argonne, IL 60439
526. H. Nickel

Furschungszentrum Jüelich (KFA)

P.0. Box 1913

Jüelich 1-5170 BRD NRW

GERMANY AIR MAIL

527. Dale E. Niesz

Rutgers University

Center for Ceramic Research

P.0. Box 909

Piscataway, NJ 08855-0909

528. David M. Nissley

United Technologies Corporation

Pratt \& Whitney Aircraft

400 Main Street, MS: 163-10

East Hartford, CT 06108

529. Richard D. Nixdorf

ReMaxCo Technologies, Inc.

11317 Snyder Road

Knoxville, TN 37932

530. Bernard North

Kennametal, Inc.

P.0. Box 639

Greensburg, PA 15601

531. Bruce E. Novich

Ceramics Process Systems

Corporation

155 Fortune Boulevard

Milford, MA 01757

532. Daniel Oblas

GTE Laboratories, Inc.

40 Sylvan Road

Wal tham, MA 02254

533. Don Ohanehi

Magnetic Bearings, Inc.

1908 Sussex Road

Blacksburg, VA 24060

534. Robert Orenstein

General Electric Company

55-112, River Road

Schenectady, NY 12345 
535. Norb Osborn

Aerodyne Dallas

151 Regal Row,

Suite 120

Dallas, TX 75247

536. A. M. Paddick

BP International Limited

BP Research Centre, Main

Library

Chertsey Road

Sunbury-on-Thames

Middlesex TW16 7LN

UNITED KINGDOM

AIR MAIL

537. Russell J. Page

Kantha 7 ..Artcor

3001 Redhill Avenue, II-109

Costa Mesa, CA 92705

538. Richard Palicka

Cercom, Inc.

1960 Watson Way

Vista, CA 92083

539. Muktesh Paliwal

GTE Products Corporation

Hawes Street

Towanda, PA 18848

540. Joseph E. Palko

General Electric Company

55-113, River Road

Schenectady, NY 12345

541. Hayre Palmour, III

Nortli Carolina State University

Materials Science and Engineering Dept.

Raleigh, NC 27605-7905

542. Joseph N. Panzarino

Norton Company

Advanced Ceramics

Goddard Road

Northboro, MA 01532-1545

543. Pellegrino Papa

Corning Inc.

AP-WX-02-1

Corning, NY 14831
544. E. Beth Pardue

Technology for Energy

Corporation

One Energy Center

P.0. Box 22996

Knoxville, TN 37933-0996

545. Soon C. Park

3M Company

3 M Center. .

Building 142-4N-02

P.0. Box 2963

St. Paul, MN 55144

546. Hartmut Paschke

Schott Glaswerke

Christoph-Dorner-Strasse 29

D-8300 Landshut

GERMANY AIR MAIL

547. Marina R. Pascucci

GTE Laboratories, Inc.

40 Sylvan Road

Waltham, MA 02254

548. James W. Patten

Cummins Engine

Company, Inc.

Materials Engineering

P.0. Box 3005, Mail

Code 50183

Columbus, IN 47202-3005

549. Robert A. Penty

Eastman Kodak Company

KAD/D73 - 35612

901 Elmgrove Road

Rochester, NY 14653

550. Robert $W$. Pepper

Textron Specialty Materials

2 Industrial Avenue

Lowe 11, MA 0185]

551. Peter Perdue

Detroit Diesel Corporation

Research Advanced Development Group

13400 West Outer Drive, Speed Code A-07

Detroit, MI 48239-4001 
552. Bruce Peters

Dow Chemical Company

Building 52

Midl and, MI 48667

553. John J. Petrovic

Los Alamos National Laboratory

Group MST-4, MS: 6771

Los Alamos, NM 87545

554. Frederick S. Pettit

University of Pittsburgh

Pittsburgh, PA 15261

555. Ben A. Phillips

Phillips Engineering Company

721 Pleasant Street

St. Joseph, MI 49085

556. Richard C. Phoenix

Ohmtek, Inc.

2160 Liberty Drive

Niagara Falls, NY 14302

557. Bruce J. Pletka

Michigan Technological University

Metallurgical and Materials

Engineering Department

Houghton, MI 49931

558. John P. Pollinger

Garrett Ceramic Componerits

19800 Van Ness Avenue

Torrance, CA 90501

559. P. Popper

High Technology Ceramics International Journal

22 Pembroke Drive

Westlands Newcastle-under-Lyme Staffs ST5 2JN

ENGLAND AIR MAIL

560. F. Porz

Universitat Karlsruhe

Institut fur Keramik Im

Maschinendau

Postfach 6980

D-7500 Karlsruhe

SERMANY

AIR MAIL
561. Harry L. Potma

Royal Netherlands Embassy

Science and Technology

4200 Linnean Avenue, N.W.

Washington, DC 20008

562. Bob R. Powell

General Motors Research Laboratories

Metallurgy. Department

30500 Mound Road

Box 9055

Warren, MI 48090-9055

563. Stephen C. Pred

ICD Group, Inc.

1100 Valley Brook Avenue

Lyndhurst, NJ 07071

564. Karl M. Prewo

United Technologies Research

Center

411 Silver Lane

MS : 24

East Hartford, CT 06108

565. Peter E. Price

Industrial Materials

Technology, Inc.

P.0. Box 9565

Andover, MA 01810

566. Joseph M. Proud

GTE Laboratories, Inc.

Materials Science Laboratory

40 Sylvan Road

Waltham, MA 02254

567. Vimal K. Pujari

Norton Company

Advanced Ceramics

Goddard Road

Northboro, MA 01532-1545

568. George Quinn

National Institute of

Standards and Technology

Ceramics Division, Bldg. 223

Gaithersburg, MD 20899 
569. Ramas V. Raman

Ceracon, Inc.

1101 North Market Boulevard, Suite 9

Sacramento, CA 95834

570. Charles F. Rapp

Owens Corning Fiberglass

2790 Columbus Road

Granville, OH 43023-1200

571. Dennis W. Readey

Colorado School of Mines

Department of Metallurgy and Materials Engineering

Golden, CO 80401

572. Wilfred J. Rebello

PAR Enterprises, Inc.

12601 Clifton Hunt Lane

Clifton, VA 22024

573. Harold Rechter

Chicago Fire Brick Company

R\&D

7531 South Ashiand Avenue

Chicago, IL 60620

574. Robert R. Reeber

U.S. Army Research office

P.0. Box 12211

Research Triangle Park, NC 27709

575. K. L. Reifsnider

Virginia Polytechnic Institute and State University

Department of Engineering Science and Mechanics

Blacksburg, VA 24061

576. Paul E. Rempes

McDonnell Douglass Missie Systems Company

P.0. Box 516, Mail Code: 1066086

St. Louis, MO 63166-0516

577. Gopal S. Revankar John Deere Company Metals Research 3300 River Drive Mol ine, IL 61265
578. K. T. Rhee

Rutgers University

Mechanical Engineering

P.0. Box 909

Piscataway, NJ 08854

579. James Rhodes

Advanced Composite Materials Corporation

1525 South Buncombe Road

Greer, SC 29651

580. Roy W. Rice

W. R. Grace and Company

7379 Route 32

Columbia, MD 21044

581. David W. Richerson

2093 East De?mont Drive

Salt Lake City, UT 84117

582. Tomas Richter

J. H. France Refractories

1944 Clarence Road

Snow Shoe, PA 16874

583. Miche1 Rigaud

Ecole Polytechnique

Campus Universite De Montreal

P.0. Box 6079, Station A

Montrea 1, P.Q Quebec H3C 3A7

CANADA AIR MAIL

584. R. E. Riman

Rutgers University

Ceramics Engineering Department

P.0. Box 909

Piscataway, NJ 08855-0909

585. Barry Ringstrom

Superior Graphite Company

P.0. Box 2373

Smyrna, GA 30081

586. John E. Ritter

University of Massachusetts

Mechanical Engineering Department

Amherst, MA 01003 
587. Frank L. Roberge

Allied-Signal Aerospace Company

Garrett Auxiliary Power Division

P.0. Box 5227

Phoenix, AZ 85010

588. W. Eric Roberts

Advanced Ceramic Technology, Inc. 990 "F" Enterprise Street Orange, CA 92667

589. Martha Rohr

U.S. Department of Energy DOE Oak Ridge Field Office Building 4500N P.0. Box 2008, MS: 6269

Oak Ridge, TN 37831-6269

590. Y. G. Roman

TNO TPD Keramick

P.0. Box 595

Einhoven 5600 AN

HOLLAND AIR MAIL

591. Mark D. Roos

Carborundum Company

P.0. Box 156

Niagara Falls, NY 14302

592. Michael Rossetti

Arthur D. Little, Inc.

15 Acorn Park

Cambridge, MA 01240

593. Barry R. Rossing

Lanxide Corporation

1300 Marrows Road

Newark, DE 19714-6077

594. Steven L. Rotz

Lubrizol Corporation

29400 Lakel and Boulevard

Wickliffe, OH 44092

595. Bruce Rubinger

Global Competitiveness, Inc.

One Devonshire Place,

Suite 1011

Boston, MA 02109
595. Robert Ruh

Wright Laboratory

WL/MLLLM

Wright-Patterson AFB, OH 45433

597. Robert J. Russe11

17 Highgate Road

Framingham, MA 01701

598. L. William Sahley

Supermaterials Company

$24400 \mathrm{Highl}$ and Road

Richmond Heights, $\mathrm{OH} 44143$

599. Jon Salem

NASA Lewis Research Center 21000 Brookpark Center

Clevel and, $\mathrm{OH} 44135$

600. W. A. Sanders

NASA Lewis Research Center 21000 Brookpark Road,

MS:49-3

Clevel and, $\mathrm{OH} 44135$

601. J. Sankar North Carolina A\&T State University

Department of Mechanical Engineering

Greensboro, NC 27411

602. Yasushi Sato

NGK Spark Plugs (U.S.A.), Inc. 1200 Business Center Drive, Suite 300

Mt. Prospect, IL 60056

603. Maxine L. Savitz

Allied-Signal Aerospace Company

Garrett Ceramic Components Division

19800 South Van Ness Avenue

Torrance, CA 90501

604. Ashok Saxena

Georgia Institute of Technology

Materials Engineering

Atlanta, GA 30332-0245 
605. David W. Scanlon Instron Corporation 100 Royall Street Canton, MA 02021

606. Charles A. Schacht Schacht Consulting Services 12 Holland Road Pittsburgh, PA 15235

607. James Schienle

Allied-Signal Aerospace Company

Garrett Auxiliary Power Division

2739 East Washington Street

P.0. Box 5227, MS: $1302-2 P$

Phoenix, AZ 85010

608. John C. Schneider

San Juan Technologies

P.0. Box 49326

Colorado Springs, CO 80949-9326

609. Gary Schnittgrund

Rocketdyne, BA05

6633 Canoga Avenue

Canoga Park, CA 91303

610. Mark Schomp

Lonza, Inc.

Corporate Headquarters

17-17 Route 208

Fair Lann, NJ 07410

611. Joop Schoonman

Delft Univer,ity of Technology Laboratory for Inorganic Chemistry

P.0. Box 5045

2600 GA Delft

THE NETHERLANDS AIR MAIL

612. John Schuldies

Industrial Ceramic Technology, Inc.

37 Enterprise Drive Ann Arbor, MI 4810?
613. Robert B. Schulz.

U.S. Department of Energy Office of Transportation

Materials CE-34, Forrestal Building Washington, DC 20585

614. Murray A. Schwartz

Materials Technology Consulting, Inc.

30 Orchard Way, North

Potomac, MD 20854

615. Peter Schwarzkopf

SRI International

333 Ravenswood Avenue

Menlo Park, CA 94025

616. Thomas C. Schweizer

Princeton Economic

Research, Inc.

12300 Twinbrook Pkwy., Suite 650

Rockville, MD 20852

617. William T. Schwessinger

Multi-Arc Scientific

Coatings

1064 Chicago Road

Troy, MI 48083-4297

618. W. D. Scott

University of Washington

Materials Science Department

Mail Stop:FB10

Seattle, WA 98195

619. Nancy Scoville

Thermo Electron Technologies

74 West Street

P.0. Box 9046

Waltham, MA 02254-9046

620. Brian Seegmiller

Coors Ceramics Company

600 9th Street

Golden, CO 80401 
621. T. B. Selover

AICRE/DIPPR

3575 Traver Road

Shaker Heights, $\mathrm{OH} 44122$

622, J. H. Selverian

GTE Laboratories, Inc.

40 Sylvan Road

Waltham, MA 02254

623. Charles E. Semler

Semler Materials Services

4160 Mumford Court

Columbus, $\mathrm{OH} 43220$

624. Thomas Service

Service Engineering Laboratory

324 Wells Street

Greenfield, MA 01301

625. Kish Seth

Ethy1 Corporation

R\&D Laboratories

P.0. Box 341

Baton Rouge, LA 70821

626. Karleen Seybold

Allied-Signal Aerospace Company

Garrett Auxiliary Power Division

P.0. Box 5227

Phoenix, AZ 85010

627. William J. Shack

Argonne National Laboratory

9700 South Cass Avenue

Building 212

Argonne, IL 60439

628. Peter T. ¿. Shaffer

Technical Leramics Laboratories, Inc.

4045 Nine/McFarland Drive

Alpharetta, GA 30201

629. Richard K. Shaltens

NASA Lewis Research Center

21000 Brookpark Road, MS:301-2

Cleveland, $\mathrm{OH} 44135$
630. Robert S. Shane

238 Hemlock Road

Wynnewood, PA 19096

631. Daniel Shanefield

Rutgers University

Ceramics Engineering Department

P.0. Box 909

Piscatawaj,- NJ 08855-0909

632. Ravi Shankar

Chromalloy

Research and Technology Division

Blaisdell Road

Orangeburg, NY 10962

633. Terence Sheehan

Alpex Wheel Company

727 Berkley Street.

New Milford, NJ 07646

634. Dinesh K. Shetty

University of Utah

304 EMRO, Dept. of Materials

Science and Engineering

Salt Lake City, UT $\mathbf{8 4 1 1 2}$

635. Masahide Shimizu

Ceramic Society of Japan

2-2-503 Takiyama 6-chome

Higashikurume-Shi Tokyo 203

JAPAN AIR MAIL

636. John Shipinski

Toyota Technical Center U.S.A., Inc.

Technical Research Department

2000 Town Center, Suite 500

Southfield, MI 48075

637. Thorias Shreves

American Ceramic Society, Inc.

Library

757 Brooksedge Plaza Drive

Westerville, $\mathrm{OH}$ 43081-2821

638. Jack D. Sibold

Coors Ceramics Company

Contracts for Corporate Technology

4545 McIntyre Street

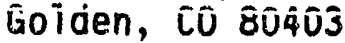


639. George H. Siegel

Point North Associates, Inc.

P.0. Box 907

Madison, NJ 07940

640. Richard Silberglitt

Technology Assessment and Transfer, Inc.

133 Defense Highway, $\$ 212$

Annapolis, MD 21401

641. Mary Silverberg

Norton Company

Advanced Ceramics Library

Goddard Road

Northboro, MA 01532-1545

642. Gurpreet Singh

Department of the Navy

Internal Combustion \& Gas

Turbine Engine Division

Code 56×31

Washington, DC 20362-5101

643. Maurice J. Sinnott

University of Michigan

Chemical and Metallurgical

Engineering

5106 IST Building

Ann Arbor, MI 48109-2099

644. John Skildum

3M Company

$3 M$ Center

Building 224-2S-25

St. Paui, MN 55144

645. David P. Smith

Hoskins, Rees \& Smith

1910 Cochran Road

Manor Oak II, Suite 658

Pittsburgh, PA 15220

646. Richard H. Smoak

Smoak \& Associates

3554 Hollyslope Road

Altadena, CA 91001-3923
647. Jay R. Smyth

Allied-Signal Aerospace Company

Garrett Auxiliary Power

Division

2739 East Washington Street

P.0. Box 5227

MS: $93-173 / 1303-207$

Phoenix, AZ 85010

648. Edward A. Snajdr

Premier Refractories and Chemicals, Inc.

P.0. Box 392

Findlay, $\mathrm{OH} 44815$

649. Rafal A. Sobotowski

British Petroleum Company

Technical Center, Broadway

3092 Broadway Avenue

Cleveland, $\mathrm{OH} 44115$

650. A. G. Solomah

SAC International Ltd.

1445 Bonhill Road, \#13

Mississauga Ontario L5T IV3

CANADA AIR MAIL

651. S. Somiya

Nishi Tokyo University

3-7-19 Seijo, Setagava

Tokyo 157

JAPAN AIR MAIL.

652. Boyd $W$. Sorenson

DuPont Lanxide Composites

1300 Marrows Road

P.0. Box 6077

Neward, DE 19707

653. Charles A. Sorrell

U.S. Department of Energy

Advanced Industrial

Concepts Division

CE-232, Forrestal

Building

Washington, DC 20585 
654. C. Spencer

EA Technology

Capenhurst Chester CHI 6ES

UNITED KINGDOM AIR MAIL.

655. Allen Spizzo

Hercules, Inc.

Hercules Plaza

Wilmington, DE 19894

656. Richard $M$ Spriggs

Alfred University

Center for Advanced Ceramic Technology

Alfred, NY 14802

657. Charles Spuckler

NASA Lewis Research Center

21000 Brookpark Road

MS: 5-11

Cleveland, $\mathrm{OH}$ 44135-3191

658. M. Srinivasan

Material Solutions

P.0. Box 663

Grand Island, NY 14702-0663

659. Gordon L. Starr

Cummins Engine Company, Inc.

Design \& Technology

P.0. Box 3005

Mail Code 50182

Columbus, IN 47202-3005

660. Jim Stevenson

Windrock, Incorporated

154 Fairbanks P1aza

Oak Ridge, TN 37830

661. Tom Stillwagon

Allied-Signal Aerospace Company

Garrett Ceramic Components Division

19800 South Van Ness Avenue

Torrance, CA 90501

662. Harold L. Stocker

General Motors Corporation

Allison Gas Turbine Division P.0. Box 420

Indianapolis, IN 46206
663. Paul D. Stone

Dow Chemical USA

1776 "Eye" Street, N.W., Suite 575

Washington, DC 20006

664. Roger S. Storm

Carborundum Company

Technology Division

P.0. Box 337

Niagara Falls, NY 14302-0337

665. Peter A. Stranges

4 Chittenden Lane

Owings Mills, MD 21117

666. F. W. Stringer

Aero \& Industrial Technology Ltd.

P.0. Box 46, Wood Top

Burntey Lancashire BB11 ABX

UNITED KINGDOM AIR MAIL

667. Thomas N. Strom

NASA Lewis Research Center

21000 Brookpark Road

MS:86-6

Cleveland, $\mathrm{OH} 44135$

668. M. F. Stroosnijder

Institute for Advanced Materials

Joint Research Centre

21020 Ispra (V:ij)

ITALY AIR MAIL

669. Karsten Styhr

30604 Ganado Drive

Rancho Palos Verdes, CA 90274

670. T. S. Sudarshan

Materials Modification, Inc. 2929-Pl Eskridge Center

Fairfax, VA 22031

671. M. J. Sundaresan

University of Miami

Mechanical Engineering Department

P.O. Box 248294

Coral Gables, FL 33124 
672. Patrick L. Sutton

U.S. Department of Energy

Advanced Propulsion Division

CE-322, Forrestal Building

Washington, DC 20585

673. Willard H. Sutton

United Technologies

Corporation

Research Center, MS:24

Silver Lane

East Hartford, CT 06108

674. Ron Sviben

100 Indel Avenue

Rancocas, NJ 08073

675. J. J. Swab

U.S. Army Materials Technology Laboratory

Ceramics Research Division

SLCMT-EMC

405 Arsenal Street

Watertown, MA 02172

676. Robert E. Swanson

Metalworking Technology, Inc.

1450 Scalp Avenue

Johnstown, PA 15904

677. Scott L. Swartz

Battelle Columbus

Laboratories

Metals and Ceramics

505 King Avenue

Columbus, $\mathrm{OH} 43201$

678. Steve Szaruga

Air Force Wright Aeronautical Laboratory

Materials Directorate

UL/MLBC

Wright-Pat terson

$A F B, O H$ 45433-6533

679. Yo Tajima

NGK Spark Plug Company, Ltd.

NTK Technical Ceramic Division 2808 Iwasaki

Komaki-shi Aichi-ken 485

JAPAN AIR MAIL
680. Fred Teeter

5 Tralee Terrace

East Amherst, NY 14051

681. Monika 0. Ten Eyck

Carborundum Company

Technology Division

P.0. Box 832

Niagara Falls, NY 14302

682. David F. Thompson

Corning Glass Works

SP-DV-02-1

Corning, NY 14831

683. Merle L. Thorpe

Hobart Tafa Technologies, Inc.

146 Pembroke Road

Concord, NH 03301

684. Eberhard Tiefenbacher

Daimler-Benz AG Abt. F1S

Mercedes-Strabe 136

Stuttgart 60

GERMANY

AIR MAIL

685. T. Y. Tien

University of Michigan

Materials Science and

Engineering Department

Dow Building

Ann Arbor, MI 48103

686. Julian M. Tishkoff

Air Force Office of Scientific Research

AFOSR/NA

Bolling AFB, DC 20332-6448

687. D. M. Tracey

Norton Company

Advanced Ceramics

Goddard Road

Northboro, MA 01532-1545

688. Dick Trippett

General Motors Corporation

Allison Gas Turbine Division

P.0. Box 420, MS:W-16

Indianapolis, IN 46206-0420 
689. L. J. Trostel, Jr.

Box 199

Princeton, MA 01541

690. W. T. Tucker

General Electric Company

Corporate R\&D

Building Kl-4C35

P.0. Box 8

Schenectady, NY 12301

691. Masanori Ueki

Nippon Steel Corporation

Central R\&D Bureau

1618 Ida

Nakahara-Ku Kawasaki 211

JAPAN AIR MAIL

692. Filippo M. Ugolini

ATA Studio

Via Degli Scipioni, 268A

ROMA 00192

ITALY AIR MAIL

693. Donald L. Vaccari

Allison Gas Turbines

P.0. Box 420

Speed Code 549

Indianapolis, IN 46206-0420

694. Carl F. Van Conant

Boride Products, Inc.

2879 Aero Park Drive

Traverse City, MI 49684

695. Marce 1 H. Van De Voorde

Commission of the European Communities

Institute for Advanced

Materials

Joint Research Centre

P.0. Box 2

1755 ZG Petten

THE NETHERLANDS AIR MAIL

696. 0. Van Der Biest

Katholieke Universiteit Leuven

Departement Metaalkunde en Toegepaste

de Croylaan 2

B-3030 Leuven

BELGIUM AIR MAIL
697. Michael Vannier

Washington University,

St. Louis

Mallinckrodt Institute of Radiology

510 South Kings Highway

St. Louis, MO 63110

698. Stan Venkatesan

Southern Coke \& Coal

Corporation

P.0. Box 52383

Knoxville, TN 37950

699. V. Venkateswaran

Carborundum Company

Niagara Falls R\&D Center

P.0. Box 832

Niagara Falls, NY 14302

700. Dennis Viechnicki

U.S. Army Materials Technology Laboratory

405 Arsenal Street

Watertown, MA 02172-0001

701. Ted Vojnovich

U.S. Department of Energy

Office of Energy Research, ER- 42

Washington, DC 20585

702. John D. Volt

E. I. Dupont de Nemours \& Company, Inc.

P.0. Box 80262

Wilmington, DE 19880

703. John B. Wachtman

Rutgers University

Ceramics Department

P.0. Box 909

Piscataway, NJ 08855

704. Shigetaka Wada

Toyota Central Research Labs, Inc.

Nagakute Aichi 480-11

JAPAN AIR MAIL 
705. Janet Wade

Allied-Signal Aerospace Company

Garrett Auxiliary Power Division, Denartment 93-772

P.0. Box 5227, MS:1303-2

Phoenix, AZ 85010

706. Richard L. Wagner

Ceramic Technologies, Inc.

537 Turtle Creek South Drive, Suite 24D

Indianapolis, IN 46227

707. J. Bruce Wagner, Jr.

Arizona State University

Center for Solid State Science

Tempe, AZ 85287-1704

708. Daniel J. Wahlen

Kohler, Co.

444 Highl and Drive

Kohler, WI 53044

709. Ingrid Wahlgren

Royal Institute of Technology

Studsvik Library

S-611 82 Nykoping

SWEDEN AIR MAIL

710. Ron H. Walecki

Allied-Signal Aerospace Company

Garrett Ceramic Components Division

19800 South Van Ness Avenue

Torrance, CA 90501

711. Michael S. Walsh

Vapor Technologies Inc.

2100 Central Avenue

Boulder, CO 80301

712. Chien-Min Wang

Industrial Technology Research Institute

Materials Research Laboratories 195 Chung-Hsing Roud, Sec. 4

Chutung Hsinchu 31015 R.O.C.

TAIWAN AIR MAIL
713. Robert M. Washburn

ASMT

11203 Col ima Road

Whittier, CA 90604

714. Gerald Q. Weaver

Carborundum Specialty Products

42 Linus Allain Avenue

Gardner, MA 01440-2478

715. Karen E. Weber

Detroit Diesel Corporation

Technology and Planning

13400 West Outer Drive

Detroit, MI 48239-4001

716. R. W. Weeks

Argonne National Laboratory

MCT-212

9700 South Cass Avenue

Argonne, IL 60439

717. Ludwig Weiler

ASEA Brown Boveri AG

Corporate Research

rppeitheimer Str. 82

D-6900 Heidelberg

GERMANY AIR MAIL

718. James Wesse1

Dow Corning Corporation

1800 "M" Street, N.W.,

Suite 325 South

Washington, DC 20036

719. Robert D. West

Therm Advanced Ceramics

P.0. Box 220

Ithaca, NY 14851

720. Thomas J. Whalen

Ford Motor Company

26362 Harriet

Dearborn Heights, MI 48127

721. Ian A. White

Hoeganaes Corporation

River Road

Riverton, NJ 08077 
722. Alan Whitehead

General Electric Company

1 River Road, 55-111

Schenectady, NY 12345

723. Sheldon M. Wiederhorn National Institute of Standards and Technology Building 223, Room A329 Gaithersburg, MD 20899

724. John F. Wight Alfred University McMahon Building Aifred, NY 14802

725. D. S. Wilkinson McMaster University Materials Science and Engineering Department 1280 Main Street, West Hamilton Ontario L8S 4L7 CANADA AIR MAIL

726. James C. Williams General Electric Company Engineering Materials Technology Labs One Neumann Way Mail Drop: $\mathrm{H85}$ Cincinnati, OH 45215-6301

727. Janette R. Williams Kollmorgen Corporation PCK Technology Division 150 Motor Parkway, \# 262 Hauppauge, NY 11788-5108

728. Steve J. Williams RCG Hagler Bailly, Inc. 1530 Wilson Boulevard, Suite 900 Arlington, VA 22209-2406

729. Craig A. Willkens Norton Company Advanced Ceramics Goddard Road Northboro, MA 01532-1545
730. Roger R. Wills TRW, Inc.

Valve Division 1455 East 185th Street Cleveland, $\mathrm{OH} 44110$

731. David Gordon Wilson Massachusetts Institute of Technology

Mechanical-Engineering Department

77 Massachusetts Avenue, Room 3-455

Cambridge, MA 02139

732. Matthew F. Winkler

Seaworthy Systems, Inc.

P.0. Box 965

Essex, CT 06426

733. Gerhard Winter

Hermann C. Starck Berlin GmbH, Werk Gosiar

P.0. Box 2540

D-3380 Gos lar 3380

GERMANY

AIR MAIL

734. W. L. Winterbottom

Ford Motor Company

Material Systems Reliability Department

20000 Rotunda Drive

SRL, Room E-3182

P.0. Box 2053

Dearborn, MI 48121

735. David G. Wirth

Coors Ceramics Company

600 9th Street

Golden, CO 80401

736. Thomas J. Wissing

Eaton Corporation

Engineering \& Research Center P.0. Box 766

Southfield, MI 48037

737. James C. Withers

MER Corporation

7960 South Kolb Road

Building $F$

Tucson, AZ 85706 
738. Dale E. Wittmer

Southern IIl inois University Mechanical Engineering Department

Carbondale, IL 62901

739. Warren W. Wolf

Owens Corning Fiberglass

2790 Columbus Road, Route 16 Granville, $\mathrm{OH} 43023$

740. George W. Wolter

Hownet Turbine Components Corporation

Technical Center

699 Benston Road

Whitehal1, MI 49461

741. James C. Wood

NASA Lewis Research Center

21000 Brookpark Road

MS:86-6

Clevel and, $\mathrm{OH} 44135$

742. Marrill Wood

LECO Corporation

Augusta Division

P.0. Box 211688

Augusta, GA 30917-1688

743. Wayne L. Worrell

University of Pennsylvania

Department of Materials

Science and Engineering

3231 Walnut street

Philadelphia, PA 19104

744. John F. Wosinski

Corning Inc.

ME-2 E-5 H8

Corning, NY 14830

745. Ian G. Wright

Battelle Columbus Laboratories

505 King Avenue

Columbus, $\mathrm{OH} 43201$

746. Ruth Wroe

ERDC

Metals \& Materials Industries

Division

Capenhurst Chester CH1 6ES

ENGLAND AIR MAIL
747. Bernard J. Wrona

Advanced Composite Materials Corporation

1525 South Buncombe Road

Greer, SC 29651

748. Carl C. M. Wu

Naval Research Laboratory

Ceramic Branch, Code 6373

Washington,-DC 20375

749. John C. Wurst

University of Dayton Research Institute

300 College Park

Dayton, OH 45469-0101

750. Neil Wyant

ARCH Development Corp.

9700 South Cass Avenue

Building 202

Argonne, IL 60439

751. Roy Yamamoto

Texaco Inc.

P.0. Box 509

Beacon, NY 12508-0509

752. John Yamanis

Allied-Signal, Inc.

Ceramics Program

P.0. Box 1021

Morristown, NJ 07962-1021

753. Harry C. Yeh

Allied-Signal Aerospace

Company

Garrett Ceramic Components Division

19800 South Van Ness Avenue

Torrance, CA 90509

754. Hiroshi Yokoyama

Hitachi Research Lab

$4026 \mathrm{Kujj-Cho}$

Hitachi-shi Ibaraki 319-12

JAPAN AIR MAIL

755. Thomas M. Yonushonis

Cummins Engine Cumpany, Inc.

P.0. Box 3005

Mail Code 50183

Columbus, IN 47202-3005 
756. Thomas J. Yost Corning, Inc.

Technical Products Division, Main Plant 21-1-2

Corning, NY 14831

757. Jong Yung

Sundstrand Aviation Operations

Department 789-6

4747 Harrison Avenue

Rockford, IL 61125

758. A. L. Zadoks

Caterpiliar Inc.

Technical Center, Building L

P.0. Box 1875

Peoria, IL 61656-1875

759. Avi Zangvil

University of Illinois

Materials Research Laboratory

104 South Goodwin Avenue

Urbana, IL 61801

760. Charles H. Zenuk

Transtech

6529 East Calle Cavalier

Tucson, AZ 85715

761. Anne Marie Zerega

U.S. Department of Energy

Office of Energy Research, ER-42

Washington, DC 20585

762. Ken Zililmer

Applied Test Systems, Inc.

2571 Mt. Gallant Road

Rock Hill, SC 29730

763. Carl Zweben

General Electric Company

P.0. Box 8555, VFSC/V4019

Philadelphia, PA 19101

764. Klaus M. Zwilsky

National Research Council

National Materials Advisory Board

2101 Constitution Avenue

Washington, DC 20418
765. Department of Energy

DOE Field Office, Oak Ridge

Assistant Manager for Energy

Research and Development

P.0. Box 2001

Oak Ridge, TN 37831-8501

765-775. Department of Energy

Office of Scientific and

Technical Information

office of Information

Services

P.0. Box 62

Oak Ridge, TN 37831

For distribution by microfiche as shown in DOE/OSTI-4500, Distribution Category UC-332

(Ceramics/Advanced Materials). 
738. Dale E. Wittmer

Southern III inois University

Mechanical Engineering Department

Carbondale, IL 62901

739. Warren W. Wolf

Owens Corning Fiberglass

2790 Columbus Road, Route 16

Granville, OH 43023

740. George W. Wolter

Howmet Turbine Components Corporation

Technical Center

699 Benston Road

Whitehal1, MI 4946]

741. James C. Wood

NASA Lewis Research Center 21000 Brookpark Road

MS: $86-6$

Clevel and, $\mathrm{OH} 44135$

742. Marrill Wood

LECO Corporation

Augusta Division

P.0. Box 211688

Augusta, GA 30917-1588

743. Wayne L. Worrell

University of Pennsylvania

Department of Materials

Science and Engineering

3231 Walnut Street

Philadelphia, PA 19104

744. John F. Wosinski

Corning Inc.

ME-2 E-5 H8

Corning, NY 14830

745. Ian G. Wright

Battelle Columbus Laboratories

505 King Avenue

Columbus, $\mathrm{OH} 43201$

746. Ruth Wroe

ERDC

Metals \& Materials Industries Division

Capenhurst Chester CHI 6ES

ENGLAND

AIR MAIL
747. Bernard J. Wrona

Advanced Composite Materials Corporation

1525 South Buncombe Road

Greer, SC 29651

748. Carl C. M. Wu

Naval Research Laboratory

Ceramic Branch, Code 6373

Washington,-DC 20375

749. John C. Wurst

University of Dayton Research Institute

300 College Park

Dayton, OH 45469-0101

750. Neil Wyant

ARCH Development Corp.

9700 South Cass Avenue

Building 202

Argonne, IL 60439

751. Roy Yamamoto

Texaco Inc.

P.0. Box 509

Beacon, NY 12508-0509

752. John Yamanis

Allied-Signal, Inc.

Ceramics Program

P.0. Box 1021

Morristown, NJ 07962-1021

753. Harry C. Yeh

Allied-Signal Aerospace Company

Garrett Ceramic Components Division

19800 South Van Ness Avenue

Torrance, CA 90509

754. Hiroshi Yokoyama

Hitachi Research Lab

$4026 \mathrm{Kuji}$-Cho

Hitachi-shi Ibaraki 319-12

JAPAN AIR MAIL

755. Thowas M. Yonushonits

Cummins Engine Company, Inc.

P.0. Box 3005

Mail Code 50183

Columbus, IN 47202-3005 

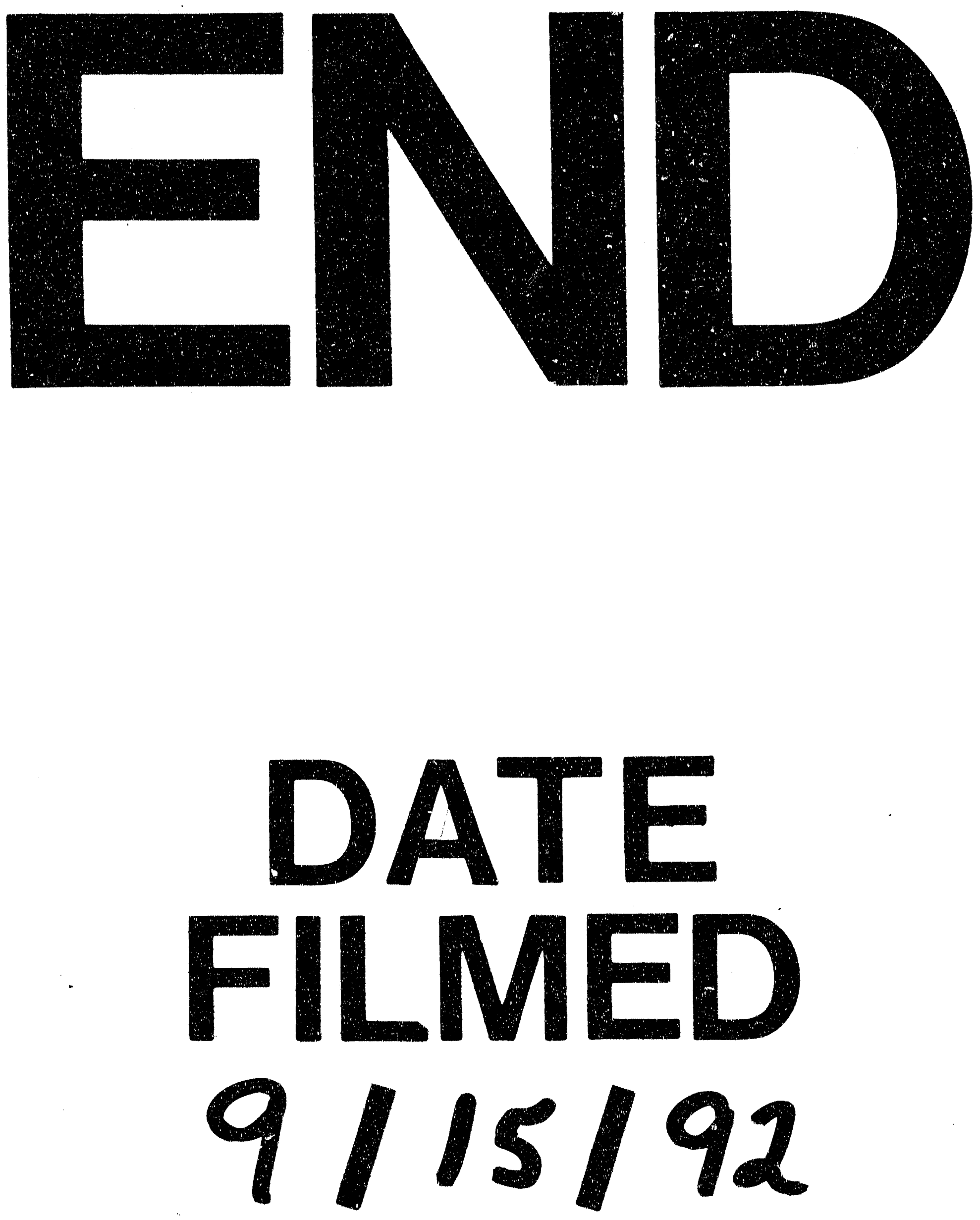

7 1 
